\title{
CICLAGEM DE NUTRIENTES E VARIAÇÕES DO MICROCLIMA EM PLANTAÇÕES DE Eucalyptus grandis Hill ex Maiden MANEJADAS ATRAVÉS DE DESBASTES PROGRESSIVOS
}

\section{LUCIANA KOLM}

Dissertação apresentada à Escola Superior de Agricultura "Luiz de Queiroz", Universidade de São Paulo, para obtenção do título de Mestre em Ciências, Área de Concentração: Ciências Florestais.

PIRACICABA

Estado de São Paulo - Brasil

Janeiro - 2001 


\title{
CICLAGEM DE NUTRIENTES E VARIAÇÕES DO MICROCLIMA EM PLANTAÇÕES DE Eucalyptus grandis Hill ex Maiden MANEJADAS ATRAVÉS DE DESBASTES PROGRESSIVOS
}

\section{LUCIANA KOLM}

Engenheira Florestal

\author{
Orientador: Prof. Dr. FÁBIO POGGIANI
}

Dissertação apresentada à Escola Superior de Agricultura "Luiz de Queiroz", Universidade de São Paulo, para obtenção do título de Mestre em Ciências, Área de Concentração: Ciências Florestais.

PIRACICABA

Estado de São Paulo - Brasil

Janeiro - 2001 


\title{
Dados Internacionais de Catalogação na Publicação (CIP) DIVISÃO DE BIBLIOTECA E DOCUMENTAÇÃO - Campus “Luiz de Queiroz"/USP
}

\author{
Kolm, Luciana \\ Ciclagem de nutrientese variações do mic roclima em plantações de \\ Eucalyptus grandis Hill ex Maiden manejadas a tra vés de desbastes \\ progressivos/ Luciana Kolm. - - Piracicaba, 2001. \\ p. : il. \\ Dissertação (mestrado) - - Escola Superior de Agricultura Luiz de \\ Queiroz, 2000. \\ Bibliografia. \\ 1. Ciclagem de nutriente 2. Decomposição 3. Desbaste 4. Ecologia \\ florestal 5. Eucalipto 6. Microclima I. Título \\ CDD 634.9734
}

“Permitida a cópia total ou parcial deste documento, desde que citada a fonte - $\mathrm{O}$ autor" 
A Deus, por guiar meus passos, Agradeço.

\begin{abstract}
A meus pais Alfredo e Lorena, pela vida, amor e apoio incondicionais; a meus irmãos André, Mônica e Daniel e toda a minha família, da qual tenho muito orgulho de fazer parte, Ofereço.
\end{abstract}

Ao meu esposo Jonas Ruschel, pelo amor e incentivo constantes, e pelo auxílio em todas as etapas deste trabalho, Dedico. 


\section{AGRADECIMENTOS}

Ao prof. Dr. Fábio Poggiani, pela valiosa orientação, amizade e incentivo, que permitiram a realização deste trabal ho.

Aos professores do Departamento de Ciências Florestais da ESALQ-USP, José Leonardo M. Gonçalves e Antônio Natal Gonçalves, e à Enga. Florestal do IPEF, Maria José Zaquia Brito, pelas valiosas sugestões e contribuições apresentadas durante o Exame Geral de Qualificação, no qual foram membros titulares.

Aos funcionários do Departamento de Ciências Florestais da ESALQ-USP, especialmente a A lba Valério Masetto e demais funcionários do Laboratório de Ecologia A plicada, pela atenção e amizade.

Ao prof. Raymond Stanley Pacovski pelo auxílio na correção do Summary.

Às bibliotecárias Silvia Zinsly e Maria Cristina Andrade pela revisão das referências bibliográficas e elaboração da ficha catalográfica.

À Coordenação de Aperfeiçoamento de Pessoal de Ensino Superior (CAPES) pelo apoio financeiro através da bolsa concedida.

À Eucatex Florestal Ltda, do grupo Eucatex S.A., através de convênio com o IPEF, pelo apoio logístico, financiamento das análises químicas e fornecimento de informações sobre a área de estudo; aos funcionários, técnico Marcelo A. P. Brisolla, pelo incansável auxílio, aos estagiários Vítor e Israel e aos funcionários Uziel, Cleiton e Toninho, por suas contribuições nos trabal hos de campo.

Ao Engo. Florestal Horácio de Figueredo Luz, pelo apoio durante a realização deste trabalho.

Aos Engos. Florestais Israel Luiz de Lima e Guilherme de Andrade Lopes, pela contribuição na col eta de dados.

Aos colegas do CPG - Ciências Florestais, pela amizade, convívio e auxílio, em especial aos outros dois mosqueteiros - Marcelino C. Guedes e Maurício S. Sartori - à Ana Cláudia Lyra e a Luciano Mendes Souza Vaz, pelas palavras de apoio.

A todas as pessoas que não foram mencionadas e que de alguma forma auxiliaram na realização deste trabal ho, meus sinceros agradecimentos. 


\section{SUMÁRIO}

Página

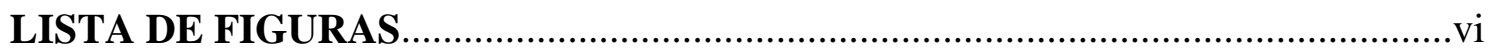

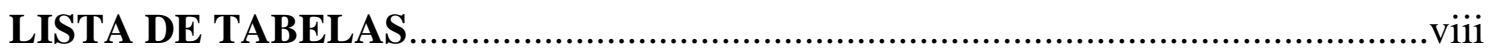

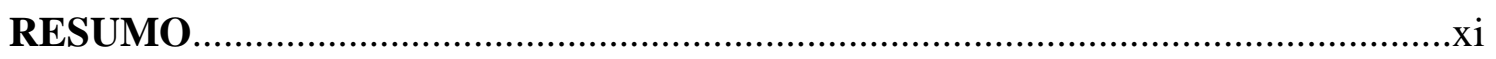

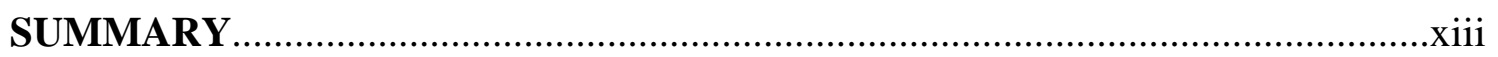

1 INTRODUÇÃ

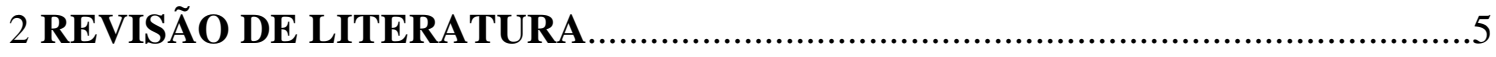

$2.1 \mathrm{O}$ método CCT de desbaste progressivo...........................................................5

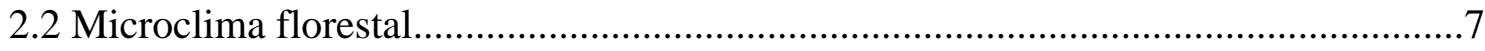

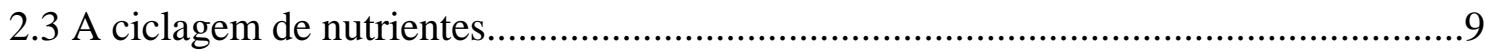

2.4 Produção e decomposição de serapilheira............................................................10

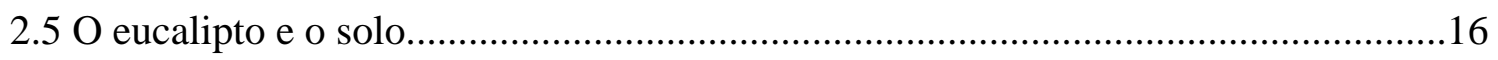

$2.6 \mathrm{O}$ manejo florestal e suas implicações ecológicas................................................19

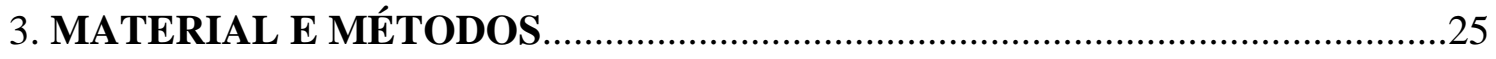

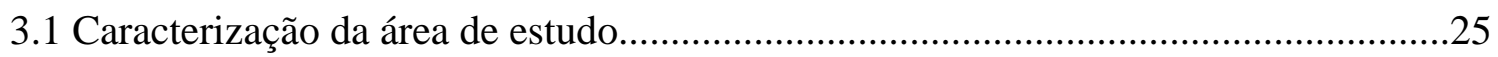

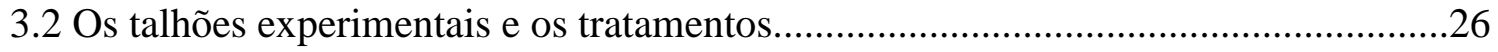

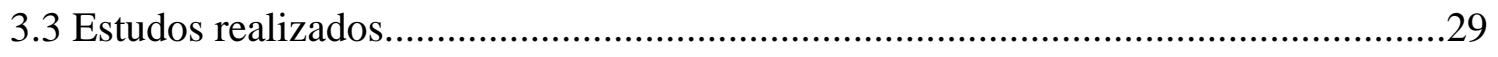

3.3.1 Variações do microclima no sub-bosque.........................................................29

3.3.1.1 Determinação do Índice de Luminosidade Relativa..........................................29

3.3.1.2 Determinação da temperatura do ar..............................................................29

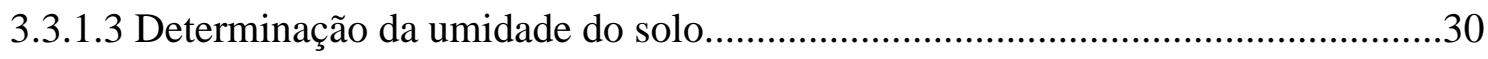

3.3.2 Estimativa de produção mensal de serapilheira................................................30

3.3.3 Estimativa de transferência mensal e anual de macronutrientes pela serapilheira...31 
3.3.4 Estimativa do estoque de serapilheira acumulada sobre o solo...............................

3.3.5 Estimativa da mineralomassa contida na serapilheira acumulada.........................33

3.3.6 Estimativa da taxa de decomposição da serapilheira..........................................33

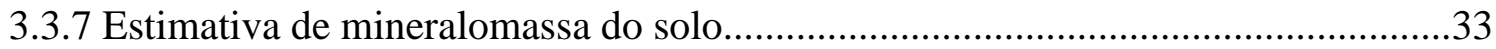

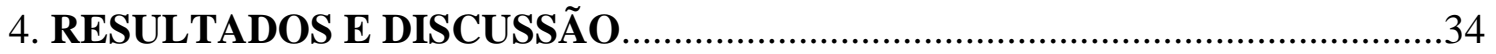

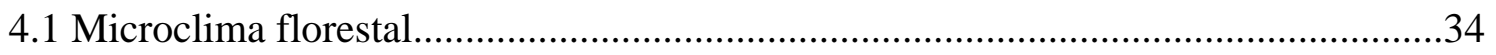

4.1.1 Radiação luminosa e Índice de Luminosidade Relativa.......................................34

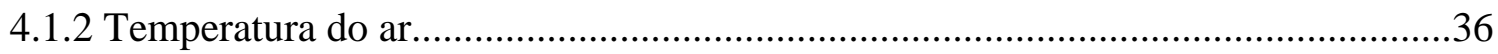

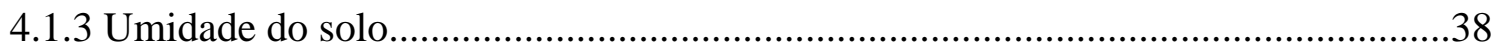

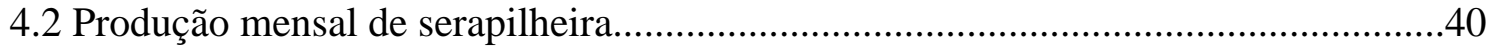

4.3 Concentrações de macronutrientes na serapilheira depositada..............................43

4.4 Transferência mensal e anual de macronutrientes via serapilheira..........................46

4.5 Estoque de serapilheira acumulada sobre o solo.................................................50

4.6 Estoque de macronutrientes na serapilheira acumulada........................................51

4.7 Decomposição da serapilheira acumulada sobre o solo.......................................53

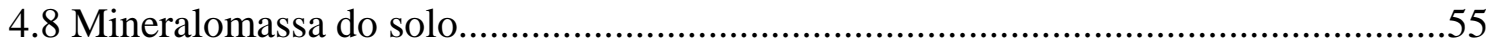

4.9 Implicações silviculturais do balanço nutricional.............................................57

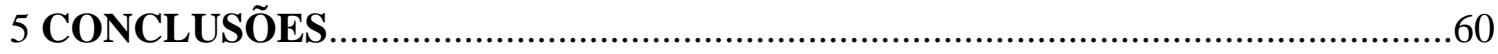

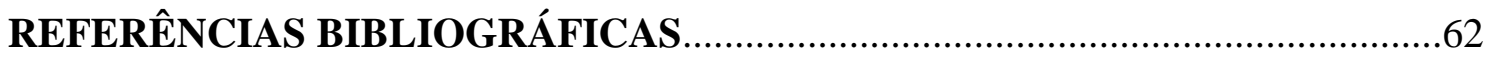




\section{LISTA DE FIGURAS}

Página

Figura 1. Visão geral do povoamento de Eucalyptus grandis sem desbaste (T0), aos 20 anos....................................................

Figura 2. Visão geral do povoamento de Eucalyptus grandis com $67 \%$

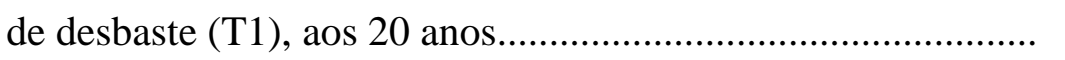

Figura 3. Visão geral do povoamento de Eucalyptus grandis com $87 \%$

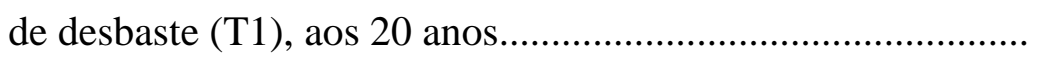

Figura 4. Utilização de molde vazado para a coleta de serapilheira

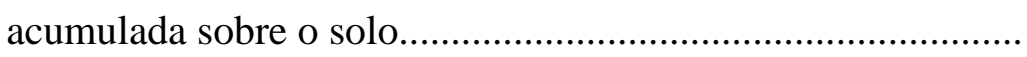

Figura 5 A) Intensidade de radiação $\left(\mu \mathrm{mol} \mathrm{m} \mathrm{m}^{-2} \cdot \mathrm{s}^{-1}\right)$ dentro e fora do povoamento florestal. B) Índice de Luminosidade Relativa (\%) no sub-bosque.

Figura 6. Temperaturas máximas, médias e mínimas mensais $\left({ }^{\circ} \mathrm{C}\right)$ nos

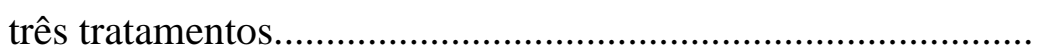

Figura 7.Umidade do solo. A) 0 a $5 \mathrm{~cm}$ de profundidade. B) 6 a $30 \mathrm{~cm}$ de profundidade. C) 31 a $60 \mathrm{~cm}$ de profundidade......................

Figura 8. Taxa mensal de deposição de serapilheira.................................

Figura 9. Taxa anual de deposição de serapilheira (outubro 1998 a setembro de 1999). 
Figura 10. Variação mensal da concentração de macronutrientes na serapilheira produzida (g Kg -1) A) Nitrogênio; B) Cálcio; C) Potássio; D) Magnésio; E) Fósforo; F) Enxofre..................

Figura 11. Deposição anual de macronutrientes ao solo..............................

Figura 12. Acúmulo médio anual de serapilheira....................................... 


\section{LISTA DE TABELAS}

Página

Tabela 1.1. Características geográficas e climáticas das áreas originais de procedência do Eucalyptus grandis e de Bofete.

Tabela 1.2. Características edáficas das áreas originais de procedência do Eucaliptus grandis e de Bofete e níveis críticos adequados para implantação e manutenção desta espécie.

Tabela 2. Taxa de mortalidade, população, diâmetro à altura do peito (1,3 m), área basal por árvore e por hectare, altura total média, volume por árvore e por hectare em plantios de Eucalyptus grandis aos 20 anos, nos 3 tratamentos

Tabela 3. Concentração dos macronutrientes $\left(\mathrm{g} \cdot \mathrm{kg}^{-1}\right)$ contidos na serapilheira produzida nos tratamentos com diferentes intensidades de desbaste, de outubro de 1998 a setembro de 1999

Tabela 4. Deposição mensal de serapilheira $\left(\mathrm{t} \cdot \mathrm{ha}^{-1}\right)$ e macronutrientes no período de estudo $\left(\mathrm{kg} \cdot \mathrm{ha}^{-1}\right)$, nos três tratamentos, no período de estudo (outubro de 1998 a setembro de 1999) 
Tabela 5. Deposição anual de serapilheira (t.ha $\left.{ }^{-1}\right)$ e macronutrientes (kg.ha ${ }^{-1}$ ), de outubro de 1998 a setembro de 1999, nos três tratamentos, comparadas com outras plantações de eucalipto

Tabela 6. Estoque de serapilheira fina acumulada sobre o solo. Resultados de duas coletas (inverno e verão) e média para o ano de estudo, em t.ha ${ }^{-1}$

Tabela 7. Concentração de macronutrientes na serapilheira acumulad

Tabela 8. Estoque de macronutrientes na serapilheira acumulada........

Tabela 9. Taxas de decomposição $(\mathrm{K})$, tempo médio de renovação da serapilheira e tempos necessários para a decomposição de $50 \%$ e $95 \%$ da serapilheira (anos)

Tabela 10. Mineralomassa do solo $\left(\mathrm{Kg} \mathrm{ha}^{-1}\right)$ na camada de $0-20 \mathrm{~cm}$ ( $\mathrm{N}$ total; $\mathrm{P}$ disponível; $\mathrm{K}, \mathrm{Ca}$ e $\mathrm{Mg}$ trocáveis)

Tabela 11. Relação entre o conteúdo de nutrientes disponíveis no solo entre 0 e $20 \mathrm{~cm}$ de profundidade e estocados na serapilheira acumulada.

Tabela 12. Estoques de nutrientes no sistema (solo $(0-20 \mathrm{~cm})+$ serapilheira acumulada). 


\title{
CICLAGEM DE NUTRIENTES E VARIAÇÕES DO MICROCLIMA EM PLANTAÇÕES DE Eucalyptus grandis Hill ex Maiden MANEJADAS ATRAVÉS DE DESBASTES PROGRESSIVOS
}

\author{
Autora: LUCIANA KOLM \\ Orientador: Prof. FÁBIO POGGIANI
}

\section{RESUMO}

O presente trabalho aborda a ciclagem de nutrientes e aspectos do microclima em plantações de Eucalyptus grandis de 20 anos, manejadas pelo método CCT, em 3 intensidades de desbaste ( $\mathrm{T} 0=0 \%, \mathrm{~T} 1=67 \%$ e $\mathrm{T} 2=83 \%$ de desbaste). As áreas de estudo localizam-se na Fazenda Santa Terezinha, propriedade da empresa Eucatex S.A., no município de Bofete - SP. O clima da região é do tipo Cwa, segundo a classificação de Köpen, e o solo é classificado como Latossolo Vermelho-Amarelo transição para Areia Quartzosa. Em relação aos aspectos microclimáticos, verificou-se que os tratamentos desbastados (T1 e T2) interceptaram menos luz que os tratamento testemunha (T0). Seus valores de radiação fotossinteticamente ativa e ILR (\%) foram, em geral, maiores que os do T0. As temperaturas mensais variaram pouco entre os tratamentos. O T2 apresentou a maior amplitude térmica, e as temperaturas médias foram ligeiramente superiores às dos demais tratamentos. Em todas as profundidades (05, 6-30 e 31-60 cm), o T0 manteve os maiores teores de umidade do solo. A deposição de serapilheira (estudada de outubro de 1998 a setembro de 1999) foi estatisticamente semelhante entre os tratamentos, embora os tratamentos com desbaste (T1 e T2) tenham depositado quantias ligeiramente maiores. Os teores de nutrientes e a sua transferência, pela deposição mensal de serapilheira, foram em geral mais altos nos tratamentos com desbaste. As taxas de deposição anual nos tratamentos T0, T1 e T2 foram de 10,2; 10,9; 10,4 t/ha/ano, respectivamente. A biomassa de serapilheira acumulada sobre o solo foi de 18,1 t/ha no T0, 13,4 t/ha no T1 e 14,8 t/ha no T2. Nos tratamentos com desbaste, os teores médios anuais de nutrientes da serapilheira acumulada foram geralmente iguais ou maiores que os do T0; porém, seus estoques foram inferiores aos do T0. A 
decomposição da serapilheira foi mais rápida nos tratamentos com desbaste, provocando menores acúmulos desta sobre o solo. Os estoques de $\mathrm{P}, \mathrm{K}, \mathrm{Ca}$ e $\mathrm{Mg}$ no solo foram superiores nos tratamentos desbastados (principalmente no T1). Devido à sua lenta velocidade de decomposição e imobilização dos nutrientes na camada de serapilheira, o T0 apresentou os menores estoques de nutrientes no solo (exceto para N). A aplicação de desbastes progressivos em povoamentos de eucaliptos, quando manejados em regimes de ciclos mais longos do que usualmente vem sendo aplicados atualmente (5 - 6 anos), podem favorecer a reciclagem dos nutrientes que entram no ecossistema, conservando mais eficientemente seus estoques no sistema (solo + serapilheira) e contribuindo para manter a produtividade do sítio. 


\title{
NUTRIENT CYCLING AND VARIATIONS OF MICROCLIMATE WITHIN A Eucalyptus grandis Hill ex Maiden PLANTATION OF A PROGRESSIVE THINNING MANAGEMENT
}

Author: LUCIANA KOLM

Adviser: Prof. FÁBIO POGGIANI

\begin{abstract}
SUMMARY
This study characterizes nutrient cycling and microclimate conditions within a 20-year-old Eucalyptus grandis plantation with three thinning intensity treatments of Correlated Curve Trend (CCT) management method $(\mathrm{T} 0=0 \%, \mathrm{~T} 1=67 \%$ and $\mathrm{T} 2=83 \%$ of thinning intensity). This project was located in Bofete - SP, in the Santa Terezinha Farm, of Eucatex S.A. The climate of site is Cwa, according to Köpen classification, and the type soil is a Haplustox with a transition to Quartz Psamment. In respect to microclimate measurements, the thinned treatments (T1 and T2) intercepted less light than the non-thinned treatment (T0). Its photosynthetic radiation and IRL (\%) were generally higher then the T0'values. Montly temperature fluctuations were minimal among the treatments. T2 presented the highest thermical fluctuation, and their temperatures were higher than the other treatments. At all soil depths (0-5, 6-30 and 31$60 \mathrm{~cm}$ ), the moisture contents were greater in T0. Litter production (measured from October, 1998 to September, 1999) was similar among the treatments, but there was somewhat more litterfall in thinned treatments (T1 and T2). Annual litterfall in treatments T0, T1 and T2 were 10.22, 10.87 and $10.39 \mathrm{t} / \mathrm{ha} /$ year respectively. The concentration of nutrients and their return through litterfall were generally greater in thinned treatments. Biomass of forest floor litter was $18.13 \mathrm{t} / \mathrm{ha}$ in T0, $13.43 \mathrm{t} / \mathrm{ha}$ in T1 and $14.83 \mathrm{t} / \mathrm{ha}$ in $\mathrm{T} 2$. Thinned treatments had equal to or higher than annual concentrations of forest floor litter when compared with T0. However, the amount of nutrients was less than T0. Litter decomposition was faster in the thinned treatments, and there was less forest floor litter in thinned treatments. Soil P, K, Ca and Mg contents were higher in thinned treatments, especially in T1. Due to its slow forest floor litter decomposition and its consequent nutrient immobilization, T0 had lower soil nutrient
\end{abstract}


contents, except for $\mathrm{N}$. The use of thinning practices in long rotation can improve nutrient cycling of atmospheric input, conserve the amount of nutrients in the soil-litter system and improve the site productivity. 


\section{INTRODUÇÃO}

A floresta, quando em equilíbrio, reduz ao mínimo a saída de nutrientes do ecossistema, através da interação do solo com a vegetação. Desta forma, o solo mantém sempre o mesmo nível de fertilidade, ou até melhora suas características ao longo do tempo. A floresta não perturbada, de forma geral, apresenta uma grande estabilidade, ou seja, os nutrientes introduzidos no ecossistema através da chuva e intemperismo geológico estão em equilíbrio com os nutrientes perdidos para os rios e o lençol freático (Poggiani, 1981).

Nas regiões tropicais úmidas, os solos tornam-se muito empobrecidos em bases e em fósforo e com alto teor de alumínio trocável. Nestas regiões, a recirculação de nutrientes, através da queda e decomposição da serapilheira, é rápida e assegura a manutenção da vegetação florestal, apesar da baixa fertilidade do solo.

Assim, os nutrientes contidos na biomassa, e aqueles encontrados na matéria orgânica dos primeiros centímetros de solo, podem desempenhar um papel vital na produtividade da floresta.

Uma forma viável de conservar as florestas naturais, em espaço de tempo relativamente curto, é o reflorestamento, para substituir a madeira usualmente retirada de florestas nativas. Grande parte dos reflorestamentos no Brasil é com eucalipto. A aptidão especial do gênero Eucalyptus para as plantações com fins comerciais, decorre especialmente dos seguintes aspectos: crescimento extremamente rápido de algumas espécies, em sítios apropriados; caráter de espécie pioneira, isto é, baixa exigência e larga amplitude ecológica; grande quantidade de espécies (cerca de 600) com diferentes exigências de sítio; simplicidade das culturas e do manejo; reduzido teor de risco do empreendimento (Lamprecht, 1990), além de possuir excelentes produtividades em 
amplas áreas reflorestadas, gerando grandes volumes de madeira para os mais variados fins (celulose e papel, dormentes, palanques, chapas aglomeradas, laminados, construção civil, postes, lenha, carvão vegetal). Ponce (1994) enfatiza que o uso de Eucalyptus como madeira serrada, embora incipiente, tem demonstrado resultados excelentes ao substituir as espécies nativas na fabricação de móveis, estruturas para telhados, paletes, casas pré-fabricadas, componentes de edificações e outras inúmeras aplicações.

Lima (1996) enfatiza que o E. grandis é provavelmente a espécie de eucalipto mais plantada do gênero em todo mundo, especialmente para a produção de madeira para a indústria. Em 1993, a estimativa de plantio desta espécie no estado de São Paulo era de aproximadamente 150 mil ha (São Paulo, 1993).

No Brasil, a produção de madeira de eucalipto tem sido feita pelo sistema de corte raso aos 6 ou 7 anos de plantio, com a condução da rebrota por uma ou duas rotações e posterior reforma do povoamento.

Porém, o manejo florestal inadequado pode interferir negativamente neste equilíbrio nutricional, se houver uma exportação de nutrientes superior à reposição proporcionada pela serapilheira depositada. O corte raso, com a retirada das árvores realizada por completo ao final do ciclo, expõe o solo às intempéries e provoca uma alta exportação de nutrientes devido à retirada dos troncos. O ciclo curto, ou seja, o corte raso da floresta durante o seu desenvolvimento, não permite que se estabeleça um ciclo de nutrientes eficiente e equilibrado, visto que o mesmo só seria conseguido na maturidade da floresta (Switzer \& Nelson, 1973). A utilização de ciclos regulares mais curtos, além de exportar altas quantidades de minerais pela retirada de madeira, antes que estes nutrientes possam ser repostos pela deposição da serapilheira, ainda expõe o solo, por repetidas vezes, aos processos de lixiviação e erosão.

Poggiani \& Schumacher (1997) verificaram que a biomassa produzida anualmente, por um talhão de E. grandis de 11 anos, foi maior que a produzida pelas outras espécies em idades semelhantes (E. camaldulensis, E. torelliana, E. saligna). E. grandis também foi a espécie mais eficiente na utilização de nutrientes, especialmente quanto ao fósforo. Entretanto, as árvores mais jovens desta espécie, com 2,5 anos de idade, acumularam proporcionalmente uma maior quantidade de nutrientes na biomassa 
do que as árvores maduras. Segundo estes autores, a exploração total das árvores para celulose e energia, em rotações curtas, reduziria significativamente a capacidade do solo de repor os nutrientes exportados, com conseqüente prejuízo da produtividade futura do sítio. Devido a este fato, para manter a capacidade produtiva do sítio, os autores sugerem que a rotação silvicultural seja mais longa que a usual (5-7 anos), e que apenas o lenho seja exportado do talhão, permanecendo as folhas, os ramos e a casca sobre o solo, conservando assim maior quantidade de nutrientes no ecossistema, e aumentando a quantidade de matéria orgânica na camada superficial do solo.

Diversos trabalhos indicam que as plantações florestais de eucalipto, quando devidamente manejadas, através de desbastes seletivos, podem produzir toras de madeiras com maiores dimensões e destinadas à indústria moveleira. Neste sentido, verifica-se atualmente, no Brasil, que povoamentos de eucaliptos e pinheiros, inicialmente plantados para a produção de celulose, vêm sendo convertidos em florestas de ciclos longos, visando melhorar as características da madeira produzida e agregar maior valor econômico.

Tendo em vista o potencial das florestas de eucalipto para usos múltiplos, um dos métodos de desbaste existentes é o uso de desbastes sucessivos - "CCT", visando a produção em ciclos mais longos. O método silvicultural "CCT" ("Correlated Curve Trend") foi criado por Craib e modificado por O'Connor para pesquisar o efeito de diferentes intensidades de desbastes sobre o crescimento de uma determinada espécie, em povoamentos puros. Embora se saiba dos efeitos positivos do método em termos produtivos e econômicos, o aspecto ecológico ainda não foi estudado, o que fez suscitar algumas dúvidas: O "CCT Method" mantém a capacidade produtiva do sítio? Qual a influência deste método no microclima e no estoque de nutrientes presentes no solo e serapilheira?

É possível que, do ponto de vista ecológico, as áreas destinadas à produção madeireira pelo método CCT possam oferecer como benefícios uma melhoria no equilíbrio ambiental pela maior diversidade e aumento da densidade do sub-bosque, e uma ciclagem de nutrientes mais efetiva. Como os desbastes são executados de forma gradual, parte-se da hipótese de que a exportação de nutrientes devido à colheita 
florestal possa ser amenizada pela deposição atmosférica, dando ao ecossistema maior sustentabilidade.

O objetivo deste trabalho foi estudar o efeito de 3 (três) intensidades de desbaste (0 \%, $67 \%$ e $83 \%$ ) pelo método CCT em talhões de Eucalyptus grandis de 20 anos na ciclagem biogeoquímica de nutrientes e em aspectos do microclima. As áreas de estudo localizam-se na Fazenda Santa Terezinha, pertencente à empresa Eucatex, no município de Bofete - SP, e os aspectos avaliados foram: variação de fatores do micro - clima no interior dos talhões (temperatura do ar, umidade do solo, luz fotossinteticamente ativa); produção (mensal e anual) e decomposição da serapilheira; concentração e estoque de macronutrientes na serapilheira depositada mensalmente e na serapilheira acumulada sobre o solo; estoque de nutrientes no solo e sistema solo + serapilheira. 


\section{REVISÃO DE LITERATURA}

\subsection{O método CCT de desbaste progressivo}

Segundo Baker (1950), as árvores dominadas de um povoamento florestal representam apenas a quarta parte do volume total em pé e da área foliar. Elas participam de apenas $10 \%$ da produção bruta, mas têm um gasto energético de $50 \%$ em sua manutenção. Desta forma, a sua participação no incremento total é quase insignificante.

Isto permite a eliminação de árvores pelo desbaste para melhorar a relação entre assimilação e respiração. Caso as remanescentes possam aproveitar a luz, água e nutrientes que eram utilizados pelas árvores dominadas, haverá um aumento no incremento florestal.

A determinação da freqüência e da intensidade de desbaste, para se obter a densidade populacional remanescente ideal de eucalipto, é uma das metas das pesquisas sobre desbastes. Uma alternativa que tem se apresentado é o método CCT (Correlated Curve Trend). Este método, criado por Craib, na África do Sul, foi descrito por Hiley (1959). O princípio básico do CCT é evitar que o povoamento entre em competição, permitindo que as árvores cresçam em ritmo acelerado, a fim de obter madeira mais homogênea e estável, além de produzir maiores volumes finais. Isso só é alcançado quando se antecipam os desbastes ao estabelecimento da competição. No método criado por Craib, a maior lotação era de 2965 árvores/ha (1200 árvores/acre), equivalente à distância de 1,83 metros (6 pés), e a menor lotação era de somente 124 árvores/ha (50 árvores/acre), com distância de aproximadamente 9,14 metros (30 pés). Segundo Hiley (1959), este método foi implementado por O’Connor, em 1935, e consistia em manter 8 
áreas amostrais representando densidades de 2965, 1483, 988, 741, 494, 371, 247 e 124 árvores/ha, ou seja, densidades de 100\%, 50\%, 33,3\%, 25\%, 16,7\%, 12,5\%, 9,3\% e 4,2\%, durante toda a rotação. As espécies estudadas na época foram Pinus patula, $P$. elliottii (P. caribaea), $P$. taeda, $P$. pinaster, $P$. radiata, $P$. roxburghii ( $P$. longifolia), $P$. caribaea (P. hondurensis) e Eucalyptus saligna. Hiley (1959) cita que o principal objetivo destas áreas experimentais é determinar se a habilidade de resposta aos desbastes (crescimento em diâmetro) é prejudicada pela alta densidade populacional no início do ciclo e, em caso afirmativo, em que proporção.

A técnica de execução é a seguinte: Assume-se a existência de um início de competição no povoamento e assim os tratamentos 2 a 8 serão reduzidos a $50 \%$ de densidade, enquanto o tratamento 1 permanece com 100\%. Seleciona-se e marca-se 50\% das árvores do tratamento 1 (de densidade 100\%), cujo DAP médio seja idêntico ao DAP médio dos tratamentos 2 a 8 (já desbastados à $50 \%$ de densidade). Quando o DAP médio das plantas selecionadas no tratamento 1 diferenciar-se ao nível de aproximadamente 2,5 $\mathrm{mm}$ (1/10 de polegadas) da média dos DAP dos tratamentos de 2 a 8, considera-se estabelecida a competição e então todos os tratamentos de 3 a 8 serão desbastados à uma densidade de 33,3\%. A seguir seleciona-se e marca-se 33,3\% das árvores (em relação à densidade inicial) do tratamento 2, cuja média dos DAP seja idêntica à média dos DAP de todos os tratamentos de 3 a 8; novamente, quando a média dos DAP do tratamento 2 diferenciar-se ao nível de 1/10 de polegada da média dos DAP dos tratamentos de números 3 a 8 , considera-se estabelecida nova competição, e então todos os tratamentos de 4 a 8 serão desbastados para uma densidade de $25 \%$. Idêntico procedimento é seguido para a efetivação dos demais tratamentos.

$\mathrm{Na}$ mesma área onde foi realizado este estudo, Luz et al. (1993) fizeram uma análise econômica simulando o corte, aos 14 anos, do povoamento em que havia sido realizado o desbaste de $83 \%$ das árvores. Os autores compararam os custos e receitas desta forma de manejo (CCT) com a exploração convencional por 2 cortes rasos $\mathrm{cm}$ rebrota (2 rotações). Luz et al. (1993) concluíram que a madeira retirada nos 4 desbastes compensa os custos de exploração e aumenta a receita total, pelo maior volume gerado 
no período. Além disso, a geração precoce de receitas melhora o fluxo de caixa e permite o retorno do investimento num prazo bem menor $\left(6^{\circ}\right.$ ano).

\subsection{Microclima florestal}

O microclima ou ecoclima refere-se ao clima na escala e no nível do organismo (ACIESP, 1997). Ao longo do perfil vertical da floresta, observa-se a alteração da temperatura, da luminosidade e da umidade do ar.

O microclima de uma floresta é caracterizado primeiramente pela modificação na luz que penetra através do dossel. Em áreas com coníferas, a luz é fortemente reduzida, mas pouco modificada qualitativamente. Já em áreas com folhosas, a luz sofre uma grande absorção seletiva, que lhe dá uma tonalidade amarelo esverdeada quando as árvores estão com folhas (Dajoz, 1978).

A fotossíntese é afetada pela quantidade e qualidade da luz. A estrutura, crescimento e inclusive a sobrevivência das plantas em uma floresta são afetados pela iluminação. A estrutura da comunidade tanto afeta a luz como é afetada por ela. Na floresta, a presença de folhas funciona como um "filtro": a luz que atinge as folhas mais altas da copa difere tanto em intensidade como em espectro daquela que atinge as folhas das plantas mais próximas ao solo. A quantidade de luz que chega ao solo de uma floresta depende das espécies presentes e da densidade das sucessivas camadas abaixo do dossel. Whatley \& Whatley (1982) citam que, quanto maior for a quantidade de luz que atinge os níveis mais baixos, melhor será o desenvolvimento das camadas baixas de vegetação, que incluem, além dos arbustos e ervas, as plântulas e árvores novas, sucessoras potenciais dos membros do dossel superior. As brechas de luz são importantes fontes de iluminação para as plantas das camadas inferiores, principalmente em florestas densas.

Quanto mais ampla a área foliar, menor a energia que chega ao sub-bosque. Spurr \& Barnes (1980) enfatizam que apenas uma pequena parte da luz incidente chega ao piso de um bosque denso. Sob as folhas de árvores caducas e que estejam sem folhas, a iluminação relativa pode chegar a ser tão alta como 50 a $80 \%$ da luz solar total; sob Pinus, 10 a 15\%; sob folhosas temperadas, 1 a 5\%; enquanto que sob florestas tropicais 
pluviais pode ser tão pequena quanto 0,25 a $2 \%$. Os autores chamam atenção, porém, à possibilidade de induzir a erros expressar a radiação em termos relativos, devido à presença de manchas de luz solar, com o passar das horas do dia.

Por outro lado, segundo Andrae (1978), a avaliação da intensidade de luz poderia ser feita em números absolutos (LUX), porém existem, dentro de um povoamento, grandes variações de sombreamento durante o caminho do sol ou devido ao movimento de folhas pelo vento, causando flutuações. E mesmo a céu aberto, a intensidade de luz está sujeita a variações contínuas, o que dificulta a definição da luminosidade em termos absolutos. Por isso, o autor recomenda que a luminosidade numa floresta seja avaliada como fração de intensidade de luz do sol disponível a céu aberto, que é chamada de Intensidade Luminosa Relativa (IRL). O mesmo autor enfatiza que a iluminação dentro de um povoamento pode ser influenciada pelo homem, e constitui um fator importante para o manejo florestal.

O calor exerce um importante papel sobre a vida das plantas, influenciando o seu crescimento, fisiologia e fenologia. De acordo com Jacobs (1988), a temperatura no interior de florestas tropicais pode ser até 7 a $10^{\circ} \mathrm{C}$ menor que fora dela, o que pode ter uma grande importância biológica. O dossel arbóreo, a vegetação do sub-bosque e a serapilheira reduzem os extremos de temperatura pela interceptação de ondas longas de radiação e mantém um maior conteúdo de umidade na superfície do solo.

Ashton (1992) salienta que medições de temperatura em dias isolados caracterizam diferenças gerais no microclima entre sítios, mas que isto não determina a amplitude das variações anuais.

Schumacher (1992), por exemplo, determinou a temperatura do ar (a 1,5 m de altura) em plantações de eucalipto, utilizando termômetros de máxima e mínima. As leituras foram realizadas das 7:00 às 19:00 h, em intervalos de $1 \mathrm{~h}$, totalizando 13 leituras em cada talhão (E. camaldulensis, E. grandis, E. torelliana). As medições foram realizadas pelo período de uma semana no verão e de outra no inverno. O autor também realizou medições de radiação global dentro e fora dos povoamentos, às 9:00, 12:00 e 15:00 horas. O E. camaldulensis, por ter ramos pendentes e copa mais rala, foi o que 
interceptou as menores quantidades de radiação solar global, e apresentou as maiores temperaturas do ar, tanto no verão como no inverno.

A umidade altera as propriedades térmicas do solo, isto é, solos secos não são bons condutores de calor. A remoção do dossel florestal pelo corte pode alterar dramaticamente os níveis de umidade do solo. Ocorre a perda de umidade pelo aumento da evaporação, e esta perda depende da densidade do dossel e da quantidade e padrão de precipitação (Pritchett \& Wells, 1978).

\subsection{A ciclagem de nutrientes}

A quantidade de nutrientes num ecossistema florestal é representada pela somatória de nutrientes contida nos diferentes compartimentos da biomassa arbórea (folhas, ramos, casca, lenho, etc.), vegetação do sub-bosque, serapilheira e solo (Poggiani \& Schumacher, 2000).

Segundo Pritchtett (1987), na floresta podem ser esquematizadas duas formas de ciclos de nutrientes: um externo e outro interno. Ao ciclo externo, ele chama também de geoquímico e inclui as formas de transferência de nutrientes para dentro e para fora do ecossistema florestal. Ao ciclo interno ele chama também de ciclo biológico, que abrange apenas a ciclagem interna de nutrientes no ecossistema florestal. Este ciclo, contudo, pode ainda ser subdividido em duas partes: o ciclo bioquímico que se refere à movimentação dos nutrientes dentro da própria árvore e o ciclo biogeoquímico que abrange a ciclagem dos nutrientes entre o solo e a biomassa arbórea. As principais formas de entrada de nutrientes nos ecossistemas são a precipitação atmosférica, o intemperismo da rocha matriz e a adubação. Quanto à saída de nutrientes, pode-se citar a erosão, lixiviação e exportação maciça de nutrientes pela exploração da floresta. A remoção de nutrientes do sítio, em função da exploração florestal, deve-se primeiramente à exportação dos nutrientes contidos na biomassa arbórea, e é proporcional à quantidade de fitomassa exportada.

A grande vantagem fisiológica que permite a sobrevivência de árvores em solos onde seria tecnicamente e economicamente impossível desenvolver atividades agrícolas, consiste na ciclagem de nutrientes, tanto bioquímica como biogeoquímica. 
Através da ciclagem interna (bioquímica), a maioria dos nutrientes (o cálcio é a exceção), são transportados dos tecidos velhos e fotossinteticamente inativos para os tecidos jovens e com grande atividade de crescimento (Poggiani, 1981). De acordo com Switzer \& Nelson (1973), até 40\% do nitrogênio e do potássio são supridos pela reciclagem interna da árvore, sendo que a maior parte do fósforo seria também fornecida desta forma. Contudo, o cálcio é um elemento fixo nos tecidos.

Um talhão florestal absorve anualmente uma quantidade de nutrientes semelhante à que absorveria uma cultura agrícola. Entretanto, menos de um terço dos nutrientes absorvidos é imobilizado na parte comercial do tronco enquanto que o remanescente volta ao reservatório do solo através da deposição de folhas, ramos, frutos e raízes, e a quantidade de elementos químicos acumulada no estágio inicial de crescimento pode ser de mais de $50 \%$ do total contido no ecossistema, incluindo solo e serapilheira acumulada (Poggiani, 1986).

Dentre os componentes da parte aérea da árvore, o maior teor de nutrientes é encontrado nas folhas, em seguida na casca, nos ramos, troncos e raízes (Curlin, 1970). No tronco, a concentração de nutrientes é muito mais baixa do que nas folhas. Pode-se dizer que o lenho do tronco de uma árvore adulta possui um teor de fósforo 70 vezes inferior ao das folhas. Para o nitrogênio, magnésio e potássio, esta proporção seria respectivamente 16, 12 e 5 vezes inferior. $\mathrm{O}$ único elemento que se conserva no lenho com um teor aproximado das folhas é o cálcio, por ser um elemento fixo nos tecidos da árvore (Divigneaud \& Denaeyer de Smet, 1973). Estas proporções, entretanto, variam de forma mais ou menos acentuada, de acordo com a espécie, a idade da planta e as características do solo.

\subsection{Produção e decomposição de serapilheira}

Pela ciclagem biogeoquímica, as folhas, ramos, flores, frutos, e fragmentos de casca que caem, após sua decomposição, liberam os nutrientes que são reutilizados para o crescimento da própria floresta. (Poggiani, 1981). Este material vegetal depositado sobre o solo é denominado serapilheira, liteira, manta orgânica ou "litter". De acordo com Cole \& Rapp (1980), esta é a principal via de transferência de C, N, P e Ca ao solo 
da floresta; o K é devolvido principalmente pela precipitação interna, e o Mg é variável entre diferentes florestas.

Bray \& Gorham (1964), concluíram, em uma revisão de âmbito mundial, que as serapilheiras amostradas, em florestas de diferentes zonas macro-ecológicas, são compostas de 60 a $80 \%$ por folhas, 1 a $15 \%$ por frutos, 12 a $15 \%$ por ramos e de 1 a $25 \%$ por cascas de árvores. Poggiani et al. (1998) citam que cerca de $70 \%$ da serapilheira produzida por um talhão florestal jovem é composta por folhas, e denominada folhedo.

$\mathrm{O}$ acúmulo de serapilheira no solo é regulado pela quantidade de material que cai da parte aérea das plantas e por sua taxa de decomposição. Quanto maior a quantidade desse material que cai e quanto menor sua velocidade de decomposição, maior será a camada de serapilheira. Portanto, é de grande importância entender os mecanismos que regulam esse processo dinâmico, no qual a entrada de material (através da deposição) e a saída ou transformação (via decomposição), acontecem quase que simultaneamente.

Carpanezzi (1980) cita dois fatores responsáveis pelos teores de nutrientes do material orgânico depositado no solo: as características de fertilidade química dos solos e as particularidades de nutrição mineral das espécies envolvidas, além da influência do regime de chuvas. Assim, dentro de certos limites, as concentrações de nutrientes em tecidos vegetais vivos estão relacionados diretamente aos teores de nutrientes do solo.

Vários fatores afetam a quantidade de resíduos que caem da parte aérea das plantas e formam a serapilheira, como o clima, o solo, as características genéticas da espécie, a idade e a densidade de plantio. De acordo com Bray \& Gorham (1964), haveria uma certa relação entre a quantidade de serapilheira depositada anualmente e a idade das árvores. Em geral se observa um aumento na deposição da serapilheira até a idade que as árvores atingem a maturidade ou fecham as suas copas. Após esse ponto pode ocorrer um ligeiro decréscimo ou uma estabilização.

A formação da serapilheira segue uma sazonalidade em função das condições climáticas ao longo do ano. Da mesma forma a decomposição da serapilheira é favorecida em períodos quentes e úmidos (Poggiani et al., 1998). Williams \& Gray (1974) citam vários fatores do meio que afetam os processos de decomposição: temperatura, umidade e aeração do solo, $\mathrm{pH}$ e conteúdo de bases, conteúdo de matéria 
orgânica solúvel em água, conteúdo de nitrogênio e conteúdo de polifenóis presentes na serapilheira.

Muitas pesquisas têm sido realizadas para verificar alguns aspectos da ciclagem de nutrientes em florestas naturais e implantadas, tais como a produção e decomposição de serapilheira. As metodologias utilizadas nestas pesquisas são muito variadas. Recentemente, vários autores estudaram a produção de serapilheira em florestas mesófilas semidecíduas no interior do estado de São Paulo, tais como Gabriel (1997), Oliveira (1997), Custódio Filho (1994) e Sparovek (1993).

Em Anhembi e Bofete, Gabriel (1997) utilizou 22 coletores de 1,00 x 1,00 m distribuídos aleatoriamente em $5300 \mathrm{~m}^{2}$, com a distância mínima de $50 \mathrm{~m}$ entre coletores. O material coletado foi separado em 4 frações para pesagem: folhas, ramos com menos de $2 \mathrm{~cm}$ de diâmetro, flores e frutos. O material vegetal foi reunido em uma amostra para as análises químicas.

Em um fragmento florestal em Piracicaba, Oliveira (1997) utilizou 96 coletores de $0,25 \mathrm{~m}^{2}$, instalados 4 a 4 , de modo a formar 24 conjuntos coletores de $1 \mathrm{~m}^{2}$, distribuídos de forma casualizada em 6 parcelas de $1000 \mathrm{~m}^{2}$. A mesma autora calculou o tamanho e o número ótimo de coletores, concluindo que 60 coletores de $0,25 \mathrm{~m}^{2}$ forneceriam melhores estimativas de deposição do que os 24 coletores de $1 \mathrm{~m}^{2}$ utilizados.

Sparovek (1993) utilizou, acoplados aos coletores de serapilheira (com diâmetro de 0,64 m), funis coletores de precipitação (com diâmetro de $0,12 \mathrm{~m}$ ). $\mathrm{O}$ autor verificou que o número de amostras necessárias para estimar a produção de serapilheira com média de $10 \%$ de variação estava entre 108 e 685 . Esta amplitude ocorreu em função dos meses do ano, com diferentes coeficientes de variação da serapilheira produzida. Em uma escala micro, como a que compreende a distância entre árvores, o autor acredita haver dependência espacial entre os valores de serapilheira produzida, ou seja, a maior parte da variância estaria na diferente produção de serapilheira de uma árvore para outra. Por isso, ele sugere trabalhar com o maior número de coletores possível, devido ao coeficiente de variação elevado. Sugere também a distribuição dos coletores ao acaso e o 
deslocamento do coletor, a poucos metros de sua posição original, no decorrer das coletas.

Custódio Filho (1994) verificou a produção de serapilheira em um trecho de Floresta Pluvial Atlântica, na Estação Biológica de Boracéia, com coletores de 1,0 x 0,5 $\mathrm{m}$, distribuídos aleatoriamente em 1 ha de floresta.

Em uma Floresta Estacional Decidual, em Santa Maria, RS, Cunha et al. (1993) instalaram 25 coletores de serapilheira, com $0,25 \mathrm{~m}^{2}$ de área de captação, distribuídos de forma sistemática, de modo a cobrir uma faixa de $10 \mathrm{~m}$ de largura acompanhando o gradiente de altitude do "Morro do Elefante", entre as cotas de 300 e 470 m. As coletas foram feitas mensalmente, durante um ano. A serapilheira foi segregada, para a pesagem, nas frações: a)folhas; b)galhos finos; c)flores, frutos e sementes; d)detritos. Posteriormente, as frações semelhantes dos coletores, correspondentes a um mês de acumulação foram reunidas para as análises químicas.

Ao estudar aspectos da ciclagem de nutrientes em talhões de Eucalyptus camaldulensis Dehnh, E. grandis Hill ex Maiden e E. torelliana F. Muell, Schumacher (1992) utilizou 20 bandejas coletoras de folhedo, de $1 \mathrm{~m}^{2}$ de superfície e amostrando uma área de $900 \mathrm{~m}^{2}$. Foi realizada a análise química das folhas resultantes de 4 amostras compostas, formadas a partir de 5 sub-amostras.

Poggiani et al. (1998) sugerem que, no uso de parcelas permanentes para o monitoramento ambiental, seja feita a estimativa de deposição de serapilheira, usando-se 5 telas coletoras com a superfície de $0,25 \mathrm{~m}^{2}$, colocadas $0,5 \mathrm{~m}$ acima do solo e distribuídas em uma parcela de $500 \mathrm{~m}^{2}$. Mensalmente o material vegetal coletado deve ser seco em estufa a $60-70^{\circ} \mathrm{C}$ para a estimativa da produção média mensal.

Conhecer a taxa de decomposição do material vegetal acumulado sobre o solo é de fundamental importância, pois é em função desta que ocorre a liberação dos nutrientes da camada de serapilheira para o solo. Como enfatizam Reis e Barros (1990), quando a taxa de decomposição é mais elevada do que a demanda pela planta poderão ocorrer perdas de nutrientes do ecossistema. Se houver equilíbrio, o nutriente liberado pela decomposição poderá ser utilizado pelas plantas, garantindo a produtividade do povoamento. Já em regiões de solos pobres e baixa precipitação, a taxa de decomposição 
pode ser mais baixa do que a demanda pela planta, impedindo a liberação de parte do nutriente até a rotação seguinte.

Têm sido usados três métodos para estudar a decomposição da serapilheira no campo. Um deles é utilizado em florestas decíduas típicas, onde o período de queda da serapilheira total é restrito; a decomposição pode ser facilmente estudada em intervalos regulares após a queda de serapilheira (Remezov, 1961). O segundo método utiliza o enclausuramento de quantidades definidas de serapilheira, que são deixados no campo por um determinado período de tempo (Attiwill, 1968). O terceiro método é aplicado onde o peso da camada de serapilheira e de sua produção anual são conhecidas e uma “constante anual de decomposição" pode ser calculada (Olson, 1963).

Cada metodologia possui suas vantagens e desvantagens. Delitti (1982) salienta que, apesar de amplamente utilizado, o método de coleta da serapilheira acumulada envolve certas imprecisões decorrentes da contaminação com partículas de solo. Entretanto, o uso de bolsas de decomposição também possui este inconveniente, como enfatizam Lousier \& Parkinson (1976) e Bahuguna et al. (1990). Estes autores acrescentam outra desvantagem do uso de bolsas: a modificação dos teores de umidade das folhas no interior das bolsas, que interferem na taxa de decomposição da serapilheira.

Dentro dos três métodos anteriormente citados existem muitas variações, de acordo com o tipo de vegetação e o objetivo da pesquisa. A seguir, estão relacionados alguns trabalhos relevantes e os respectivos métodos utilizados.

Poggiani et al. (1998) sugerem, em parcelas permanentes de monitoramento ambiental, a coleta semestral da serapilheira acumulada sobre o solo, em 10 amostras de $0,25 \mathrm{~m}^{2}$, que após a secagem, fornecerão a quantidade de serapilheira acumulada.

Para verificar a serapilheira acumulada sobre o solo, Oliveira (1997) coletou 6 amostras (uma por parcela) em duas coletas, uma no final da estação seca e outra no final da estação chuvosa, utilizando um quadrado de madeira de $0,25 \mathrm{~m}^{2}$. Para a obtenção destas amostras, a autora coletou toda a manta existente sobre o solo.

Cunha et al. (1993) coletou, mensalmente, 10 amostras de $0,25 \mathrm{~m}^{2}$ da manta acumulada sobre o solo. Gabriel (1997) estimou o estoque de serapilheira acumulada 
através de coletas mensais de todo o material vegetal existente sobre o solo, em 6 quadrados de 0,5 x 0,5m. Custódio Filho (1994) coletou 10 amostras, em 4 períodos do ano, por meio de um quadrado de madeira de $1 \mathrm{~m}^{2}$ locado aleatoriamente sobre o solo.

Custódio Filho (1994) também avaliou a porcentagem de decomposição da serapilheira com bolsas de tela de náilon (malha de $1 \mathrm{~mm}^{2}$ ). Nestas bolsas foram colocadas folhas recém caídas que compunham a serapilheira, previamente secas, e a cada dois meses eram retiradas 10 bolsas, aleatoriamente.

Para determinar a taxa de decomposição, Gabriel (1997) utilizou 40 bolsas de náilon $(10$ x $20 \mathrm{~cm})$, com malha de $2 \mathrm{~mm}^{2}$, e introduziu $10 \mathrm{~g}$ de material foliar recém caído, primeiramente seco a $70^{\circ} \mathrm{C}$ até peso constante. A cada 3 meses, 8 bolsas eram retiradas da floresta para determinara a diferença entre o peso seco inicial e o final.

Em plantações de Shorea robusta e Eucalyptus camaldulensis, na Índia, Bahuguna et al. (1990), utilizaram 48 bolsas de náilon de 30 x $23 \mathrm{~cm}$ distribuídas casualmente no solo florestal. As bolsas continham várias aberturas de cerca de $2 \mathrm{~mm}$, para facilitar o movimento da fauna edáfica. Em cada bolsa, foram colocadas $100 \mathrm{~g}$ de folhas frescas previamente secas da serapilheira. A cada 30 dias a partir da colocação das bolsas, 4 bolsas de folhedo de cada espécie foram desenterradas das plantações e levadas a laboratório para estudar a população de fauna e a decomposição e liberação dos nutrientes do folhedo.

Harmon et al. (1990) avaliaram a decomposição da liteira em uma floresta de Picea e Tsuga em Washington, EUA. Os autores utilizaram bolsas de 20 x $20 \mathrm{~cm}$, com malha de 0,8 mm. Em cada bolsa, foram colocadas $10 \mathrm{~g}$ do folhedo seco ao ar de uma das 11 espécies mais comuns na área de estudo.

Na Etiópia, Lisanework \& Michelsen (1994) estudaram a decomposição da serapilheira de duas espécies exóticas (Cupressus lusitanica e Eucalyptus globulus) de 28 a 40 anos de idade, com a espécie nativa Juniperus procera e com a floresta montana de Juniperus-Olea-Podocarpus. $25 \mathrm{~g}$ de folhas recém caídas foram colocadas em bolsas de náilon de $20 \times 20 \mathrm{~cm}$, com malha de $2 \mathrm{~mm}$. Trinta e duas bolsas foram colocadas aleatoriamente em cada área florestal. A camada de serapilheira foi removida para a 
colocação das bolsas, e após utilizadas para cobri-las. Em cada área, foram coletadas aleatoriamente 4 bolsas a cada 3 meses, durante o período de dois anos.

Peterson et al. (1979) estudaram a taxa de decomposição da serapilheira em uma floresta não perturbada em área de aluvião, sujeita a inundações. Foram usadas amostras de $72 \mathrm{~g}$ de folhedo fresco, colocadas em contêineres de tecidos de ferragens galvanizadas com malha de $7 \mathrm{~mm}$ e área de $1,65 \mathrm{~cm}^{2}$. Em cada parcela amostral, foram colocados doze contêineres. Coletou-se uma amostra por parcela, a cada bimestre.

Para estudar a decomposição de 4 espécies florestais (Pinus banksiana, Betula papyrifera, Populus tremuloides e Quercus ellipsoidalis), nos EUA, Bockheim et al. (1991) utilizaram bolsas de decomposição de 15 x $15 \mathrm{~cm}$ de fibra de vidro com 250 mesh (topo) e tecido de náilon de 2000 mesh (baixada). 24 bolsas foram enchidas com 3 a $6 \mathrm{~g}$ de folhas e fechadas com grampos. Foram retiradas 4 bolsas em cada uma das 6 coletas ao longo de um ano.

Hart et al. (1992) utilizaram bolsas de decomposição de serapilheira para estudar uma floresta jovem (aproximadamente 10 anos) e uma floresta antiga (mais de 100 anos de idade) de Pinus ponderosa, na Califórnia. Os autores utilizaram $10 \mathrm{~g}$ de acículas secas ao ar, colocadas em bolsas de náilon de 10 × $20 \mathrm{~cm}$, com malha 3 x $4 \mathrm{~mm}$. Grupos de 10 bolsas de serapilheira ( 5 contendo acículas da floresta jovem e 5 contendo acículas da floresta antiga) foram locadas em intervalos de $5 \mathrm{~m}$ ao longo de um transecto em cada parcela, sendo 10 replicatas para cada classe de idade por parcela, em cada uma das 5 datas de amostragem (total de 100 bolsas de acículas por parcela). Isto determinou os 4 tratamentos: serapilheira da floresta antiga colocada na floresta antiga e na floresta jovem, e serapilheira da floresta jovem colocada na floresta antiga e na floresta jovem. Uma bolsa de cada tratamento foi aleatoriamente selecionada e removida de cada grupo de bolsas após 1, 3, 12 e 24 meses.

\subsection{O eucalipto e o solo}

Os solos utilizados para o florestamento são geralmente muito pobres e às vezes sujeitos à forte erosão e lixiviação, devendo-se estudar os efeitos de intervenções sucessivas da colheita de madeira com máquinas pesadas sobre as propriedades edáficas. 
Segundo Novais et al. (1990), os reflorestamentos no Brasil tem sido feitos principalmente em solos sob vegetação de cerrado, caracterizados como de baixa fertilidade natural, alto grau de acidez e, em geral, grande desuniformidade pluviométrica. De acordo com estes autores, a elevada acidez dos solos condiciona a alta atividade de alumínio e de alguns micronutrientes como o manganês e o ferro e, paralelamente, a menor disponibilidade de outros nutrientes, como o fósforo, e a baixa eficiência da fertilização química que lhe for adicionada. Embora a maioria das culturas necessite de correção do alumínio trocável para obtenção de bons índices de produtividade, o eucalipto, no entanto, possui exigências de fertilidade do solo bem inferiores.

É reconhecido que há, a longo prazo, um acúmulo de nutrientes na camada superior de solos sob florestas, devido à absorção contínua de nutrientes de camadas mais profundas do solo pelas raízes, e que são depositados no piso florestal, através da lavagem das copas e da deposição de material orgânico. A seguir, os nutrientes depositados são incorporados ao solo (Carpanezzi, 1980). Embora o acúmulo superficial seja útil para compensar a evasão de nutrientes do ecossistema, já que há uma retenção considerável de nutrientes na madeira exportável, Ovington (1968) adverte que retiradas intensas de madeira podem ocasionar um declínio na produtividade, pela incapacidade de o solo gerar quantidades equivalentes às dos nutrientes exportados. A quantificação periódica de nutrientes disponíveis no solo e na serapilheira permite uma avaliação da influência das plantações sobre as reservas químicas e previne a ocorrência de situações nutricionais críticas.

Segundo Gonçalves et al. (1996), a camada de solo que tem teores de nutrientes mais relacionados com o crescimento das árvores é a de 0-20 cm de profundidade, onde ocorrem com mais profundidade os processos de absorção pelas raízes. Gonçalves (1994) enfatiza que, na camada de solo de 0 a $10 \mathrm{~cm}$ de profundidade, há uma grande atividade de raízes finas, devido à maior disponibilidade de nutrientes do solo e aos processos de ciclagem biogeoquímica, via deposição e mineralização da serapilheira. Este autor constatou que, em 17 povoamentos florestais de E. grandis (idade média de 5,6 anos), os pesos médios de raízes finas decresceram exponencialmente de 790 para 45 
$\mathrm{Kg} \mathrm{ha}^{-1}$, respectivamente, das camadas 0-10 para 100-150 cm. 38, 51 e 60\% das raízes foram encontradas nas camadas 0-10, 0-20 e 0-30 cm, respectivamente, e os 40\% restantes, na camada $30-150 \mathrm{~cm}$.

A qualidade da serapilheira depositada pelas diferentes espécies florestais altera de forma significativa, em poucos anos, as características químicas do solo superficial, influenciando também o processo de regeneração natural do subbosque (Poggiani \& Monteiro Júnior, 1990). Este fato também foi verificado por Haag et al. (1978), ao comparar solos sem cobertura vegetal com solos sob povoamentos de Pinus taeda e Eucalyptus citriodora de 20 e 30 anos, respectivamente.

Segundo revisão feita por Fonseca et al. (1993), a maior ou menor quantidade de nutrientes que retornam ao solo pela manta orgânica é função, dentre outros fatores, da densidade do povoamento, da composição de espécies, da época do ano, da maturidade do povoamento e da atividade dos microorganismos do solo.

Lima (1996) realizou uma extensa revisão sobre o estudo do efeito das plantações de eucalipto sobre as propriedades químicas do solo, salientando que há inúmeros trabalhos publicados, principalmente na região do Mediterrâneo. Alguns resultados são contraditórios, levando-se em conta as diferenças climáticas e edáficas entre diferentes regiões do mundo. Quanto ao $\mathrm{pH}$ do solo, Lima (1996) verificou que, enquanto alguns autores verificaram ligeira diminuição do $\mathrm{pH}$, outros encontraram aumento do $\mathrm{pH}$ no solo reflorestado com eucalipto. $\mathrm{O}$ autor salienta que em relação ao teor de nutrientes e ao conteúdo de cátions trocáveis, a grande maioria dos trabalhos mostra resultados altamente favoráveis, tendo o reflorestamento com eucalipto proporcionado aumento no teor da maioria dos cátions trocáveis estudados. Mesmo em relação ao potássio trocável, sugerido por alguns autores como sendo muito extraído do solo pelo eucalipto, tem sido observada, em outras situações, tendência a aumentar a sua concentração no solo sob plantação de eucalipto.

Fonseca et al. (1993) verificaram um acúmulo das bases trocáveis (Ca, Mg e K) na superfície do solo, independente do tipo de cobertura vegetal. Os valores mais elevados de $\mathrm{Ca}$ e $\mathrm{Mg}$ trocáveis observados no solo sob Eucalyptus paniculata, comparativamente aos observados sob E. citriodora, devem-se, segundo eles, às 
diferenças na produção de biomassa e às diferenças nas necessidades nutricionais destas espécies. Os autores ainda sugerem a existência de uma maior quantidade destes nutrientes imobilizados na biomassa da floresta do que no solo.

$\mathrm{O} \mathrm{K}$ é um elemento de grande lixiviação nos solos altamente intemperizados e profundos, como os normalmente usados para o plantio de eucalipto, e não se acumula de maneira significativa nos solos, como acontece com o fósforo (Novais et al., 1990). Muitos solos tropicais, especialmente os de cerrado, possuem teores baixos de potássio, isto é, abaixo de $40 \mathrm{mg} \cdot \mathrm{dm}^{-3}$ (Lopes, 1983). De acordo com Barros \& Novais (1990), a necessidade de potássio das plantas de eucalipto aumenta com o acúmulo de biomassa e com a idade da planta, e esse aumento deve estabilizar-se quando a ciclagem de nutrientes for mais intensa, o que ocorre provavelmente dos 4 aos 5 anos após o plantio.

A maior preocupação com o Ca, segundo Novais et al. (1990), e que deve ser considerada ao longo das rotações, é embasada na pobreza deste elemento nos solos utilizados para o plantio de eucalipto, e de sua grande retirada com a exploração da floresta. Bellote et al. (1980), avaliando a quantidade de nutrientes exportados por $E$. grandis, aos 7 anos de idade, encontraram que aproximadamente $580 \mathrm{~kg}$ de Ca são exportados pelo corte de um volume de madeira com casca igual a $355 \mathrm{~m}^{3} / \mathrm{ha}$, sendo este o elemento mais exportado em termos quantitativos.

Neves et al. (1982), testaram o efeito do Al sobre quatro espécies de eucaliptos, verificando a elevada tolerância de todas as espécies testadas, que estão dispostas na seguinte ordem decrescente quanto à tolerância ao Al: E. urophylla $>$ E. paniculata $>E$. grandis $>$ E. cloeziana. Desta forma, não parece ser necessária a correção do Al trocável do solo para o cultivo do eucalipto.

\subsection{O manejo florestal e suas implicações ecológicas}

Alvo de inúmeras polêmicas, o eucalipto é considerado uma planta causadora de efeitos maléficos sobre o solo e o ecossistema, por alguns autores. Outros pesquisadores, porém, o defendem como uma forma de evitar o esgotamento das reservas florestais remanescentes. O que parece evidente, porém, é que o seu efeito negativo, assim como o 
de qualquer outra espécie, exótica ou não, deve-se mais ao manejo florestal incorreto que à uma característica inerente à espécie.

Dentre as técnicas de manejo intensivas adotadas nos programas de reflorestamento no Brasil, e que podem ter forte reflexo na ciclagem de nutrientes, merecem destaque o preparo da área (tanto na implantação como na reforma de povoamentos), a adubação mineral, a densidade de plantio, a seleção de material genético e a exploração florestal (idade e componentes utilizados). $\mathrm{O}$ aumento na densidade de plantio normalmente leva ao corte do povoamento em idade mais jovem, visto que a capacidade produtiva do sítio é atingida mais cedo. Por isso, muitas vezes o balanço de nutrientes do sistema não alcança um equilíbrio, pois antes que os nutrientes imobilizados na serapilheira sejam liberados um novo corte é realizado. Ademais, o solo é exposto em um maior número de vezes ao tráfego de máquinas, ao sol e à chuva, o que acentua os distúrbios no ciclo de nutrientes. A exploração feita em idades mais avançadas permite, também, uma ciclagem interna de nutrientes mais eficiente (Reis et al., 1990).

$\mathrm{O}$ encurtamento da rotação expõe o solo por um maior período de tempo às intempéries climáticas do que em rotações longas, o que pode ser prejudicial, pois aumenta a drenagem de nutrientes pela lixiviação e erosão.

Segundo Powers (1976), o corte raso pode estimular a nitrificação, resultando em perdas significativas de nitrato, principalmente em solos de textura grosseira.

As florestas implantadas de alto rendimento, quando manejadas de maneira inadequada podem extrair grandes quantidades de nutrientes, acarretando a conseqüente perda de produtividade do sítio, a menos que pesadas adubações sejam efetuadas. A quantidade de nutrientes exportados depende da espécie utilizada, da idade de corte e da utilização total ou parcial da árvore.

Nas árvores de uma floresta homogênea, verifica-se que, na fase juvenil, o peso da copa é superior ao peso do tronco, e grande parte dos carboidratos é canalizada para a produção de biomassa da copa. Contudo, com o passar dos anos, quando as copas começam a competir entre si, a produção relativa do tronco cresce de forma exponencial e a da copa diminui, gradativamente. Como o teor de nutrientes do tronco é sempre 
menor do que o teor de nutrientes da copa, a exportação final de elementos minerais é proporcionalmente sempre menor nos talhões mais velhos, cujos troncos representam quase o peso total da biomassa. A biomassa da copa sempre representa uma pequena parcela da árvore total, mas com um elevado teor de elementos minerais (Poggiani, 1981; Schumacher, 1998). Além disso, Lima (1996) enfatiza que, durante a formação do cerne da madeira, os nutrientes normalmente são translocados da madeira, e o cerne normalmente conterá menor concentração de nutrientes que o alburno. Como nas espécies de eucalipto, o cerne começa a se formar em torno dos 8 anos, o corte de árvores mais jovens pode remover mais nutrientes do que o corte de em idades mais avançadas.

Um aspecto muito importante da implantação da floresta manejada intensivamente foi a tendência para encurtar as rotações e aumentar a taxa de utilização da biomassa e com isso, a de aumentar as quantidades de nutrientes removidas (Pereira, 1978). O corte e a retirada total das copas a rotações curtas poderá ter sérias consequiências no equilíbrio nutricional da floresta. É desejável que nas florestas manejadas intensivamente, somente o tronco seja explorado.

A exportação de nutrientes por plantações de eucalipto, em idades correspondentes à da época de corte, nas rotações curtas para a produção industrial, é significativa e representa uma demanda considerável sobre o capital de nutrientes do solo. Desta forma, sucessivas rotações, mesmo em sítios de boa fertilidade, devem influenciar negativamente a produtividade (Wells \& Jorgensen, 1979), (Wise \& Pitman, 1981), (Raison \& Crane, 1981), (Raison et alii, 1982), (Poggiani et alii, 1983), (Poggiani, 1985).

Poggiani (1985), esquematizou o comportamento de uma plantação de Eucalyptus saligna, média para o período compreendido pela variação da idade de 7 a 10 anos, no que diz respeito ao acúmulo de nutrientes nos componentes da biomassa, à transferência de nutrientes ao solo pela deposição do folhedo e ao capital de nutrientes disponíveis no perfil de $180 \mathrm{~cm}$ do solo (1240 kg N/ha, $59 \mathrm{~kg}$ P/ha, $277 \mathrm{~kg} \mathrm{~K} / \mathrm{ha}, 7956$ $\mathrm{kg} \mathrm{Ca} / \mathrm{ha}, 1243 \mathrm{~kg} \mathrm{Mg} / \mathrm{ha}$ ), calculando também o tempo de esgotamento dos nutrientes disponíveis do solo em função da quantidade armazenada na biomassa das árvores. 
Admitindo-se que não ocorressem adições de nutrientes pelas chuvas, pelo intemperismo ou por adubação, o resultado mostrou que o suprimento do solo em fósforo daria para 11,5 anos, enquanto que o do potássio daria para 15,8 anos.

Feller (1983), estudando a ciclagem de nutrientes em plantações de Pinus radiata na Austrália, chegou à conclusão de que o regime de rotação curta conduz à diminuição da produtividade do sítio mesmo em condições de solo mais fértil.

Para uma dada espécie o custo de reposição é muito sensível à idade do talhão, e será um fator importante na determinação do melhor regime de rotação, ou seja, do regime de rotação que possibilite a permanência das condições originais de fertilidade do sítio ao longo de sucessivas rotações (Poggiani, 1985).

A gestão do capital mineral do sítio torna-se mais importante à medida que aumenta a proporção desse capital que é removida, e a velocidade de remoção se aproxima ou ultrapassa a velocidade de entrada de nutrientes no ecossistema. Kimmins (1974), introduziu o conceito de rotação ecológica, definida como a rotação que permite o retorno do sítio às condições ecológicas iniciais. Para se manter a fertilidade do sítio, as rotações não devem ser mais curtas do que a rotação ecológica.

A saída de nutrientes de um ecossistema, através da colheita da madeira, pode ser determinada pela análise química e pesagem do lenho e casca, e determinação da densidade básica da madeira e casca. Schumacher (1997) encontrou as seguintes quantidades de biomassa e nutrientes na casca e no lenho de E. globulus subespécie bicostata aos 4 anos de idade (espaçamento $3 \times 2 \mathrm{~m}$ ): casca: 6,2 t/ha (biomassa), 13,1 kg N/ha, 2,5 kg P/ha, 24,4 kg K/ha, 213,7 kg Ca/ha e 13,7 kg Mg/ha; lenho: 42,0 t/ha (biomassa), 50,4 kg N/ha, 5,4 kg P/ha, 79,8 kg K/ha, 37,8 kg Ca/ha e 12,6 kg Mg/ha.

Poggiani, Suiter \& Couto (1980), mostraram que uma plantação de Eucalyptus grandis aos 2,5 anos, em regime de mini-rotação, produziu, no espaçamento de $1 \mathrm{x}$ 1,5m, 72,3 toneladas de madeira por hectare e 85,7 toneladas por hectare de fitomassa, incluído o material da copa das árvores. Este resultado eqüivale a uma produtividade de quase 30 toneladas de madeira por hectare por ano. A extração de nutrientes pelo fuste foi de $371 \mathrm{~kg} / \mathrm{ha}(5,13 \mathrm{~g} / \mathrm{kg}$ de fitomassa), e pela fitomassa total foi de $699 \mathrm{~kg} / \mathrm{ha}(8,15$ $\mathrm{g} / \mathrm{kg}$ de fitomassa). Comparativamente, um talhão de Eucalyptus saligna no 
espaçamento de $3 \times 2 \mathrm{~m}$ em condições ecológicas semelhantes, mas cortado aos 8 anos produziu uma fitomassa de 106 toneladas/ha, das quais 90 toneladas eram de madeira, e exportou $651 \mathrm{~kg}$ de nutrientes/ha na fitomassa total $(6,12 \mathrm{~g} / \mathrm{kg}$ de fitomassa), sendo 441 apenas do fuste $(4,90 \mathrm{~g} / \mathrm{kg}$ de fitomassa). Neste talhão, a produtividade foi de cerca de 13 t/ha/ano, ou seja, 2,3 vezes inferior ao anterior. De maneira genérica, poderia-se dizer que um talhão no espaçamento de $1,5 \times 1,0 \mathrm{~m}$ pode, nos primeiros anos, produzir o dobro de fitomassa por ha/ano em relação a um talhão mais velho, no espaçamento de 3 x $2 \mathrm{~m}$. Este resultado é muito promissor, porém é preciso saber se esta produtividade irá se manter em sucessivas rotações no espaçamento de $1,5 \times 1,0 \mathrm{~m}$, tendo em vista a competição e esgotamento do solo.

Poggiani (1984) estudou a exportação de nutrientes através da exploração de talhões de Eucalyptus grandis, E. saligna e E. urophylla plantados em três espaçamentos diferentes: $1,0 \times 1,5 \mathrm{~m}, 2,0 \times 1,5 \mathrm{~m}$ e 3,0 × 1,5 m. Verificou-se que para $E$. grandis e $E$. saligna o conteúdo total de nutrientes $(\mathrm{N}, \mathrm{P}, \mathrm{K}, \mathrm{Ca}$ e $\mathrm{Mg}$ ) nas árvores foi superior no espaçamento 3,0 x 1,5 m, (com exceção do fósforo no E. saligna), enquanto que para o E. urophylla, o conteúdo de nutrientes foi superior no espaçamento $2,0 \times 1,5 \mathrm{~m}$. Em relação à exportação de nutrientes (N, P, K, Ca e Mg) por ocasião do primeiro corte dos povoamentos aos 2,5 anos de idade, esta foi crescente com o aumento do espaçamento apenas para o E. saligna $(174,36 \mathrm{~kg} / \mathrm{ha}$ para o espaçamento $1,0 \times 1,5 \mathrm{~m} ; 263,20$ para 2,0 x 1,5 m e 291,90 para 3,0 x 1,5 m). O E. urophylla foi o que obteve os maiores índices de exportação de nutrientes. O autor também estabeleceu o que Hansen \& Baker (1979) chamam de "eficiência de utilização dos nutrientes", ou seja, a quantidade de nutrientes necessária para se produzir certa quantidade de biomassa, verificando que o Eucalyptus grandis foi a espécie mais eficiente $(9,57 \mathrm{~kg}$ de nutrientes/ tonelada de biomassa).

Poggiani (1986) encontrou as seguintes quantidades de biomassa e nutrientes na casca e no lenho de E. saligna aos 11 anos de idade: casca: 9,5 t/ha (biomassa), contendo $25,1 \mathrm{~kg} \mathrm{~N} / \mathrm{ha}, 12,2 \mathrm{~kg}$ P/ha, 47,9 kg K/ha, 448,3 kg Ca/ha e 30,5 kg Mg/ha; lenho: 158,5 t/ha (biomassa), contendo 112,5 kg N/ha, 30,1 kg P/ha, 72,9 kg K/ha, $103,0 \mathrm{~kg} \mathrm{Ca} / \mathrm{ha} \mathrm{e}$ $15,8 \mathrm{~kg} \mathrm{Mg} / \mathrm{ha}$. 
De acordo com Ferreira (1989), que estudou plantações de eucalipto em solos arenosos, em região de Cerrado, há uma tendência de maiores concentrações de N, P, K, $\mathrm{Ca}$ e $\mathrm{Mg}$ ocorrerem no tronco e casca de árvores adubadas, o que não é observado na folhagem e ramos. Ainda que as mesmas quantias de madeira e casca sejam colhidas de árvores adubadas no plantio, maiores quantias de $\mathrm{N}, \mathrm{P}, \mathrm{K}, \mathrm{Ca}$ e $\mathrm{Mg}$ serão removidas do sítio, ao compararmos com árvores não adubadas. Se a madeira e a casca são extraídas, somente o requerimento de magnésio será provavelmente suprido através das entradas via atmosfera. Outros nutrientes virão das reservas do solo ou da adição de fertilizantes. $\mathrm{O}$ descascamento dos troncos pode diminuir grandemente a remoção de $\mathrm{Ca}, \mathrm{Mg}$ e $\mathrm{K}$, se a casca permanecer no sítio. Na casca estão, respectivamente, 80, 70 e $60 \%$ dos nutrientes contidos no fuste. Assim, somente P e N terão remoção líquida do sítio. 


\section{MATERIAL E MÉTODOS}

\subsection{Caracterização da área de estudo}

O experimento foi realizado na Fazenda Santa Terezinha, propriedade da Empresa Eucatex S.A., município de Bofete, na região centro - sul de SP. A área experimental situa-se entre as coordenadas geográficas de $23^{\circ} 04^{\prime}$ de latitude Sul e $48^{\circ} 13^{\prime}$ de longitude Oeste. A altitude é de aproximadamente $500 \mathrm{~m}$. O Clima é do tipo Cwa, segundo a classificação de Köpen. A precipitação anual é de 1200 mm, ocorrendo cerca de 4 meses de seca na região. De acordo com Gabriel (1997), o clima da região é caracterizado por uma estação seca bem definida que coincide com o inverno quando, em anos esporádicos, há ocorrência de geadas. A estação chuvosa é bastante pronunciada e vai de outubro a março, sendo responsável por $73,5 \%$ da precipitação anual.

Na tabela 1.1 estão descritas algumas características geográficas e climáticas dos locais de origem do Eucalyptus grandis, na Austrália, e em Bofete-SP. Na tabela 1.2 é feita uma comparação entre os teores de nutrientes encontrados nas regiões de origem do E. grandis, na Austrália, e da área manejada para serraria em Bofete - SP.

Tabela 1.1. Características geográficas e climáticas das áreas originais de procedência do Eucaliptus grandis e de Bofete*.

\begin{tabular}{|l|c|c|c|c|}
\hline Localidade & Latitude & Altitude & $\begin{array}{c}\text { Chuva } \\
(\mathrm{mm})\end{array}$ & $\begin{array}{c}\text { Meses } \\
\text { secos }\end{array}$ \\
\hline Coff's Harbour - NSW Austrália & $30^{\circ} \mathrm{S}$ & $10 \mathrm{~m}$ & 1650 & 0 \\
\hline Athert - QLD Austrália & $17^{\circ} \mathrm{S}$ & $800 \mathrm{~m}$ & 1400 & 4 \\
\hline Bofete SP - Brasil & $23^{\circ} \mathrm{S}$ & $500 \mathrm{~m}$ & 1200 & 4 \\
\hline
\end{tabular}

* Fontes parciais de Novais et al. (1986) e Barros (1990). 
O solo de Bofete é um Latossolo Vermelho - Amarelo, transição para Areia Quartzosa (Luz et al., 1993), extremamente pobre e ácido, de textura arenosa. Na tabela 1.2, observa-se claramente a discrepância entre os teores naturais de bases e de matéria orgânica do solo das regiões de origem, na Austrália, e de Bofete.

Tabela 1.2. Características edáficas das áreas originais de procedência do Eucalyptus grandis e de Bofete, e níveis críticos adequados para implantação e manutenção desta espécie *:

\begin{tabular}{|c|c|c|c|c|c|c|c|c|c|c|c|}
\hline \multirow{2}{*}{ Localidade } & \multirow{2}{*}{$\begin{array}{l}\mathrm{pH} \\
\mathrm{H}_{2} \mathrm{O}\end{array}$} & \multirow{2}{*}{$\begin{array}{c}\mathrm{P} \\
\mathrm{mg} \\
\mathrm{dm}^{-3}\end{array}$} & $\mathrm{~K}$ & $\mathrm{Ca}$ & $\mathrm{Mg}$ & CTC & $\mathrm{Al}$ & $\begin{array}{l}\mathrm{V} \\
\%\end{array}$ & Argila & Areia & \multirow{2}{*}{\begin{tabular}{|l} 
M.O. \\
$\mathrm{g} \mathrm{dm}^{-3}$ \\
\end{tabular}} \\
\hline & & & \multicolumn{5}{|c|}{$\mathrm{mmol}_{\mathrm{c}} \mathrm{dm}^{-3}$} & \multicolumn{3}{|c|}{$\%$} & \\
\hline $\begin{array}{l}\text { Coff's Harbour } \\
\text { NSW - Austrália }\end{array}$ & 5,7 & 1,5 & 2,7 & 53,3 & 25,5 & 90 & - & 90 & 28 & 47 & 6,2 \\
\hline $\begin{array}{l}\text { Atherton } \\
\text { QLD - Austrália }\end{array}$ & 4,5 & 1,7 & 2,7 & 11,2 & 9,4 & 77 & 47 & 31 & 24 & 71 & 5,9 \\
\hline $\begin{array}{l}\text { Bofete } \\
\text { SP - Brasil }\end{array}$ & $3,9^{* *}$ & 5,5 & 0,25 & 3,4 & 1,6 & 48 & 8,0 & 13 & 7 & 91 & 1,5 \\
\hline $\begin{array}{l}\text { Níveis críticos: } \\
\text { Implantação } \\
\text { Manutenção }\end{array}$ & $>4,5$ & $\begin{array}{l}60 \\
4 \\
\end{array}$ & $\begin{array}{l}0,5 \\
2,1\end{array}$ & $\begin{array}{l}8,0 \\
7,0\end{array}$ & $\begin{array}{l}3,5 \\
3,0\end{array}$ & $>60$ & $>30$ & $>30$ & - & - & - \\
\hline
\end{tabular}

* Fontes parciais de Novais et al. (1986) e Barros (1990), modificados.

** $\mathrm{pH} \mathrm{CaCl} \mathrm{Ca}_{2}$

\subsection{Os talhões experimentais e os tratamentos}

O experimento foi instalado em talhões de Eucalyptus grandis plantados em 1978, no espaçamento de 3,0 x 1,5 m.. Foram realizados até quatro (4) desbastes sucessivos pelo método "CCT", durante os primeiros 7 anos, resultando na retirada de até $83 \%$ da população inicial de 2220 árvores/ha. As épocas e intensidades dos desbastes foram determinadas por parcelas experimentais de acompanhamento, nas quais se fez a previsão do início da competição entre as árvores, para assim antecipar o desbaste. As árvores remanescentes dos primeiros desbastes e também a testemunha foram desramadas até a altura de $6 \mathrm{~m}$. 
Os tratamentos avaliados foram:

T0 - Testemunha (sem desbastes);

T1 - $67 \%$ de desbaste ( 2 desbastes: $1^{\circ}$ aos 3 anos e $2^{\circ}$ aos 4 anos de idade);

T2 - 83\% de desbaste ( 4 desbastes: $1^{\circ}$ aos 3 anos, $2^{\circ}$ aos 4 anos, $3^{\circ}$ aos 6 anos e $4^{\circ}$ aos 7 anos de idade).

$\mathrm{Na}$ tabela 2, encontram-se algumas características e nas figuras 1, 2 e 3 pode-se visualizar o aspecto geral dos tratamentos T0, T1 e T2, respectivamente.

Tabela 2. Taxa de mortalidade, população, diâmetro à altura do peito $(1,3 \mathrm{~m})$, área basal por árvore e por hectare, altura total média, volume por árvore e por hectare, em plantios de Eucalyptus grandis aos 20 anos, nos três tratamentos.

\begin{tabular}{|c|c|c|c|c|c|c|c|c|c|}
\hline \multirow{2}{*}{ Trat. } & \multirow{2}{*}{ Desbaste } & \multirow{2}{*}{$\begin{array}{c}\text { Mortalidade } \\
\%\end{array}$} & \multirow{2}{*}{$\begin{array}{c}\text { População } \\
\mathrm{N}^{\circ} \text { árvores } \\
\text { /ha }\end{array}$} & \multirow{2}{*}{$\begin{array}{l}\text { DAP } \\
\text { Médio } \\
\mathrm{cm}\end{array}$} & \multicolumn{2}{|c|}{ Área Basal } & \multirow{2}{*}{$\begin{array}{l}\text { Altura } \\
\text { média } \\
\text { m }\end{array}$} & \multicolumn{2}{|c|}{ Volume em pé* } \\
\hline & & & & & $\mathrm{m}^{2} / a ́ r v o r e$ & $\mathrm{~m}^{2} / \mathrm{ha}$ & & $\mathrm{m}^{3}$ /árvore & $\mathrm{m}^{3} / \mathrm{ha}$ \\
\hline T 0 & $0 \%$ & 38,2 & 1511 & 19,2 & 0,02895 & 43,7 & 29,8 & 0,484 & \begin{tabular}{|l|}
731,4 \\
\end{tabular} \\
\hline $\mathrm{T} 1$ & $67 \%$ & 1,9 & 770 & 24,9 & 0,04870 & 37,5 & 38,7 & 0,963 & 741,6 \\
\hline T 2 & $83 \%$ & 2,4 & 380 & 30,1 & 0,07112 & 27,0 & 42,9 & 1,444 & 548,3 \\
\hline
\end{tabular}

* Os volumes retirados nos desbastes dos trat. T0, T1 e T2 foram: 0,118 e $236 \mathrm{~m}^{3} \mathrm{ha}^{-1}$, respectivamente.

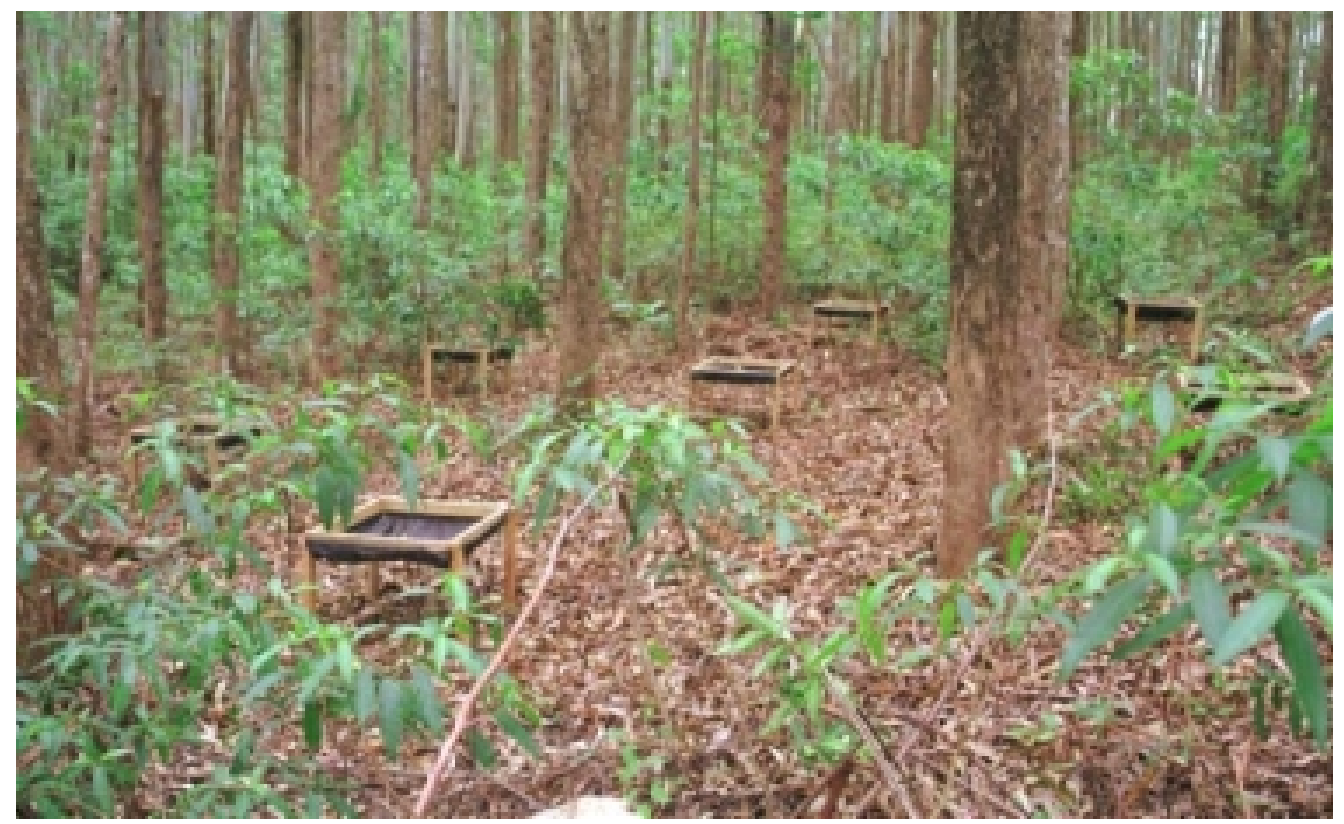

Figura.1. Visão geral do povoamento de Eucalyptus grandis sem desbaste (T0), aos 20 anos. 


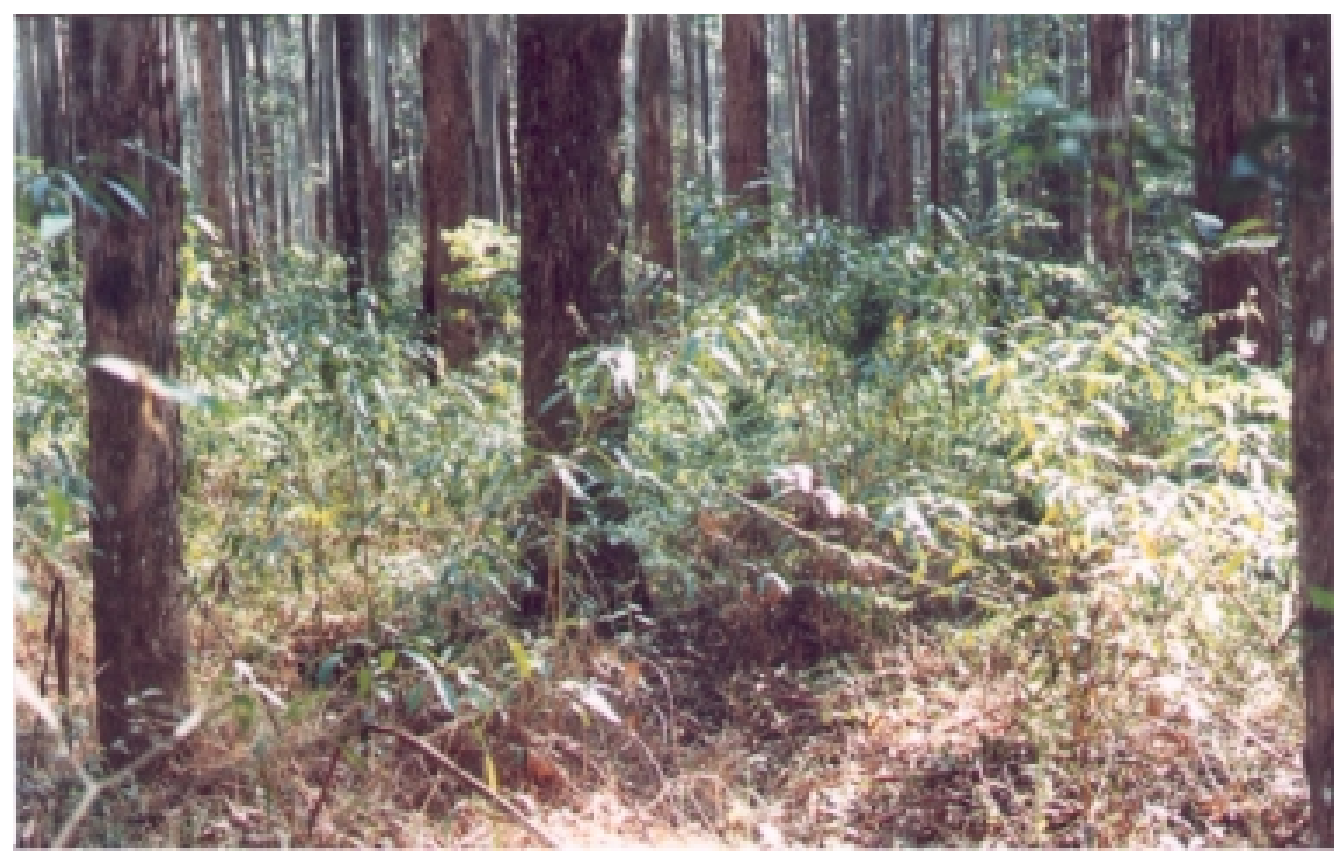

Figura 2. Visão geral do povoamento de Eucalyptus grandis com $67 \%$ de desbaste (T1), aos 20 anos.

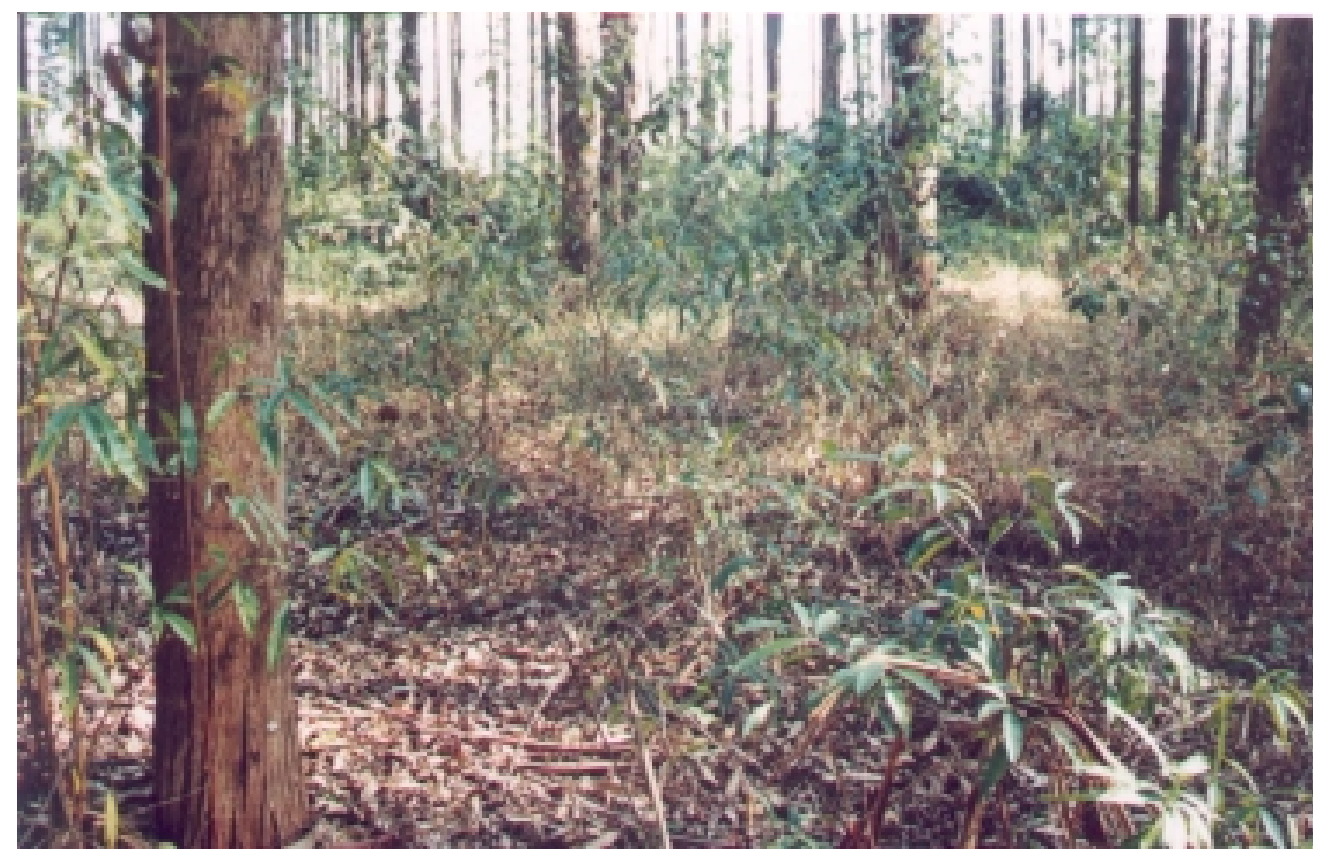

Figura 3. Visão geral do povoamento de Eucalyptus grandis com $83 \%$ de desbaste (T2), aos 20 anos. 
Os estudos desenvolvidos nesta pesquisa foram realizados dos 20 aos 21 anos de idade dos povoamentos. Para cada tratamento havia apenas um talhão plantado. Portanto, as repetições foram efetuadas de forma sistemática, dentro de cada talhão. $\mathrm{Na}$ metodologia de cada item de estudo, está descrito o número de repetições utilizado. Os resultados obtidos foram submetidos à análise de variância e à comparação de médias pelo teste de Tukey a $5 \%$ de probabilidade, utilizando-se o programa estatístico SASSystem for Windows release 6.11 (SAS Institute Corporation, 1996).

\subsection{Estudos realizados}

\subsubsection{Variação do microclima no sub-bosque}

\subsubsection{Determinação do Índice de Luminosidade Relativa}

Foi medida a radiação fotossinteticamente ativa (400 a $700 \mathrm{~nm}$ ) nos meses de abril, junho, julho, agosto e setembro de 1999. As medições de cada mês foram realizadas em um único dia sem nuvens, entre as 11 e as $13 \mathrm{~h}$, tanto a céu aberto como no interior dos talhões, com um PAR. As leituras de cada mês foram realizadas em um único dia. Primeiramente foram feitas 5 leituras a pleno sol, em locais próximos ao povoamento, e a seguir foram feitas 20 leituras no interior das parcelas (sub-bosque).

De posse do valor de leitura externa, representando a luz que incide sobre a floresta, e da média das leituras dentro de cada talhão, calculou-se o Índice de Luminosidade Relativa (IRL), obtido a partir da expressão:

$$
\mathrm{IRL}=\frac{\text { Luz debaixo do dossel }}{\text { Luz acima do dossel }} \times 100
$$

\subsubsection{Determinação da temperatura do ar}

Utilizou-se, em cada tratamento, um termômetro de máxima e mínima tipo capela colocado a $1,5 \mathrm{~m}$ do nível do solo. Os termômetros foram instalados no final do mês de março de 1999. Foram realizadas as leituras das temperaturas máximas e mínimas mensais, no período de abril a outubro de 1999. De posse destas leituras, foram calculadas as temperaturas médias de cada mês. 


\subsubsection{Determinação da umidade do solo}

Foram coletadas 7 amostras simples por tratamento, nas profundidades de 0 - 5, 6 - 30 e 31 - $60 \mathrm{~cm}$, nos meses de abril a outubro de 1999. A amostragem de cada mês foi feita num único dia, juntamente com as leituras de luz e temperatura. As amostras foram acondicionadas em sacos plásticos hermeticamente fechados. Ao chegar em laboratório, foram pesadas em balança de precisão (peso úmido) e secas a $80^{\circ} \mathrm{C}$ até atingirem peso constante. Em seguida eram novamente pesadas (peso seco). Por diferença, era obtido o valor da umidade do solo.

\subsubsection{Estimativa de produção mensal de serapilheira}

Foram distribuídos no interior dos talhões de cada tratamento, 7 coletores de serapilheira, de $0,25 \mathrm{~m}^{2}$ de superfície $(0,50 \times 0,50 \mathrm{~m})$. A moldura e os pés dos coletores foram construídos em madeira. No interior da moldura de cada coletor, fixou-se uma tela de náilon (sombrite) com malha de 1,5 x 1,5 mm. A parte central das telas tinha forma côncava, de tal modo a permitir o acúmulo da serapilheira e facilitar o escoamento da água através das malhas. As bandejas foram suspensas a $0,50 \mathrm{~m}$ de altura (para evitar contaminações), numeradas e distribuídas de forma sistemática na parte central dos talhões, para evitar o efeito de bordadura (Figura 1). A serapilheira depositada nos coletores ou armadilhas foi recolhida mensalmente, durante 12 meses, de outubro de 1998 a setembro de 1999. Como serapilheira considerou-se todo o material vegetal composto por folhas, casca, frutos e ramos finos com menos de $1 \mathrm{~cm}$ de diâmetro (serapilheira fina). A serapilheira foi seca em estufa a $50-60^{\circ} \mathrm{C}$, no Laboratório de Ecologia Aplicada do Departamento de Ciências Florestais da ESALQ, até alcançar peso constante. Com os valores de peso seco estimou-se a deposição média mensal de serapilheira por hectare. 


\subsubsection{Estimativa de transferência mensal e anual de macronutrientes pela serapilheira}

As amostras do material vegetal coletado nas bandejas de cada talhão foram moídas separadamente em moinho tipo Willey e o pó resultante foi peneirado através de uma malha 20. Alíquotas destas amostras foram utilizadas para análise de macronutrientes (N, P, K, Ca, Mg e S). O Nitrogênio foi determinado por destilação, seguido de titulação pelo método Microkjeldahl. As determinações de Potássio, Cálcio e Magnésio foram realizadas por fotometria de chama, em um espectrofotômetro de absorção atômica, o Fósforo foi determinado pelo método do vanado-molibdato, por colorimetria e o Enxofre, por colorimetria (Sarruge \& Haag, 1974). Com os valores das concentrações de cada um dos macronutrientes analisados e os valores mensais da serapilheira depositada por hectare, estimou-se a quantidade de nutrientes transferidos mensalmente ao solo pela serapilheira.

\subsubsection{Estimativa do estoque de serapilheira acumulada sobre o solo}

A coleta de serapilheira acumulada sobre o solo foi realizada colocando sobre o piso das plantações de eucalipto um molde vazado de madeira com $0,25 \mathrm{~m}^{2}$ de área $(0,5$ x 0,5 m). Com o auxílio de uma espátula, foram retiradas, em cada parcela, 7 amostras de serapilheira presente na área delimitada pelo molde (Figura 4). Como serapilheira considerou-se todo o material vegetal depositado sobre o solo, composto por folhas, casca, frutos e ramos finos com menos de $1 \mathrm{~cm}$ de diâmetro (serapilheira fina). A avaliação da biomassa foi realizada em duas épocas: inverno (julho/1998) e verão (fevereiro/1999). Estas amostras foram levadas ao Laboratório de Ecologia Aplicada da ESALQ, para secagem em estufa de circulação forçada a $50-60^{\circ} \mathrm{C}$, até alcançarem peso constante. Após a secagem, foram pesadas, sendo estimada, posteriormente, a biomassa da serapilheira acumulada sobre o solo, em cada um dos tratamentos. 


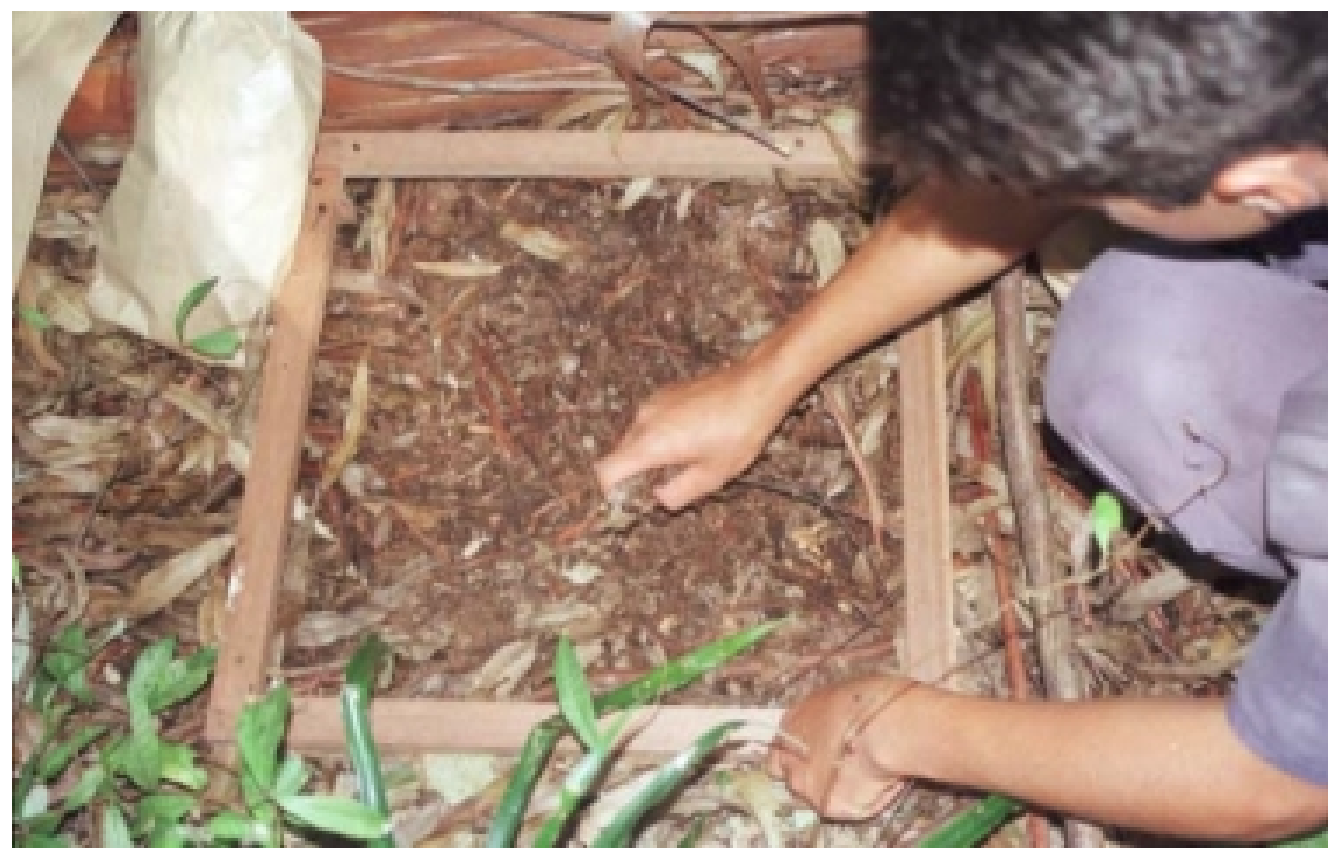

Figura 4. Utilização do molde vazado para a coleta da serapilheira acumulada sobre o solo.

\subsubsection{Estimativa da mineralomassa contida na serapilheira acumulada}

As mesmas amostras coletadas para a estimativa do estoque de serapilheira acumulada (item 3.3.4) foram utilizadas para a análise de nutrientes. Após a secagem, foram moídas em moinho do tipo Willey, peneiradas em malha 20 e levadas para análise de macronutrientes (N, P, K, Ca e Mg) no Laboratório de Ecologia Aplicada da ESALQ. Conhecendo-se o estoque de serapilheira e a sua concentração de macronutrientes, calculou-se o estoque de macronutrientes na serapilheira acumulada sobre o solo.

\subsubsection{Estimativa das taxas de decomposição da serapilheira}

Para estimar a taxa de decomposição da serapilheira utilizou-se o método proposto por Olson (1963).Por este método, a taxa de decomposição (K) foi calculada utilizando os valores de produção anual de serapilheira (L) e de seu acúmulo sobre o solo $\left(\mathrm{X}_{\mathrm{ss}}\right)$. 


\section{$\mathbf{K}=\mathbf{L} / \mathbf{X}_{\mathrm{ss}}$}

A quantidade de serapilheira acumulada sobre o solo varia de acordo com a época do ano. Portanto, no presente estudo foram realizadas duas coletas, uma no inverno (julho de 1998) e outra no verão (fevereiro de 1999), obtendo-se um valor médio anual de serapilheira acumulada.

Calculou-se também, a partir do valor de $\mathrm{K}$, o tempo médio de renovação da quantidade de serapilheira acumulada, estimado por $1 / \mathrm{K}$, e os tempos necessários para o desaparecimento de $50 \%$ (t 0,5) e 95\% (t 0,05) da serapilheira:

$$
\begin{aligned}
& \text { t } 0,5=0,693 / K \\
& \text { t } 0,05=3 / K
\end{aligned}
$$

\subsubsection{Estimativa da mineralomassa do solo}

A amostragem de solo para estimar o conteúdo de nutrientes (mineralomassa) foi realizada na parte central das unidades amostrais, a uma distância mínima de duas linhas de plantio da bordadura. Foram coletadas 7 amostras por tratamento na profundidade de 0-20 cm. Estas amostras foram coletadas com uma sonda de solo, no inverno (mês de julho). Foram acondicionadas em sacos plásticos e levadas ao Laboratório de Ecologia Aplicada do Departamento de Ciências Florestais, na ESALQ. As amostras de terra foram secas ao ar e passadas em peneira de 2,0 $\mathrm{mm}$. A terra fina resultante foi submetida a análises químicas ( $\mathrm{N}, \mathrm{P}, \mathrm{K}, \mathrm{Ca}$ e $\mathrm{Mg}$ ) e análises físicas (densidade aparente). O Nitrogênio total foi determinado pelo método Semi-micro Kjeldahal; P, resina e colorimetria; $\mathrm{K}, \mathrm{Ca}$ e $\mathrm{Mg}$ pelo método espectrofotométrico. Conhecendo-se as concentrações dos nutrientes e a densidade do solo, foi possível estimar o estoque de nutrientes do solo dos três tratamentos estudados. 


\section{RESULTADOS E DISCUSSÃO}

\subsection{Microclima florestal}

\subsubsection{Radiação luminosa e Índice Relativo de Luminosidade}

$\mathrm{Na}$ Figura 5, encontram-se as médias mensais das leituras de intensidade de radiação (PAR) no sub-bosque e fora dos povoamentos florestais (Figura 5A), bem como os Índices Relativos de Luz, nos três tratamentos (Figura 5B). Deve-se ressaltar que o valor de cada mês foi medido em um único dia, o que possibilita comparações entre os tratamentos, embora não caracterize a média mensal.

Dentre os meses avaliados, o mês de abril apresentou os maiores valores de radiação e IRL, e os meses de junho e julho, os menores valores. Estes resultados estão relacionados com a produção de serapilheira (que será tratada no item 4.2), sendo que os meses de maior deposição de serapilheira foram os de maior incidência de luz no subbosque, e vice-versa.

Tanto a radiação como o IRL foram maiores nos tratamentos desbastados. Os desbastes propiciaram uma menor interceptação da radiação fotossinteticamente ativa que incide sobre a floresta, permitindo uma maior penetração da radiação solar para o interior do povoamento. De acordo com Spurr e Barnes (1980), a iluminação na altura do piso florestal está inversamente relacionada com a densidade das copas. 

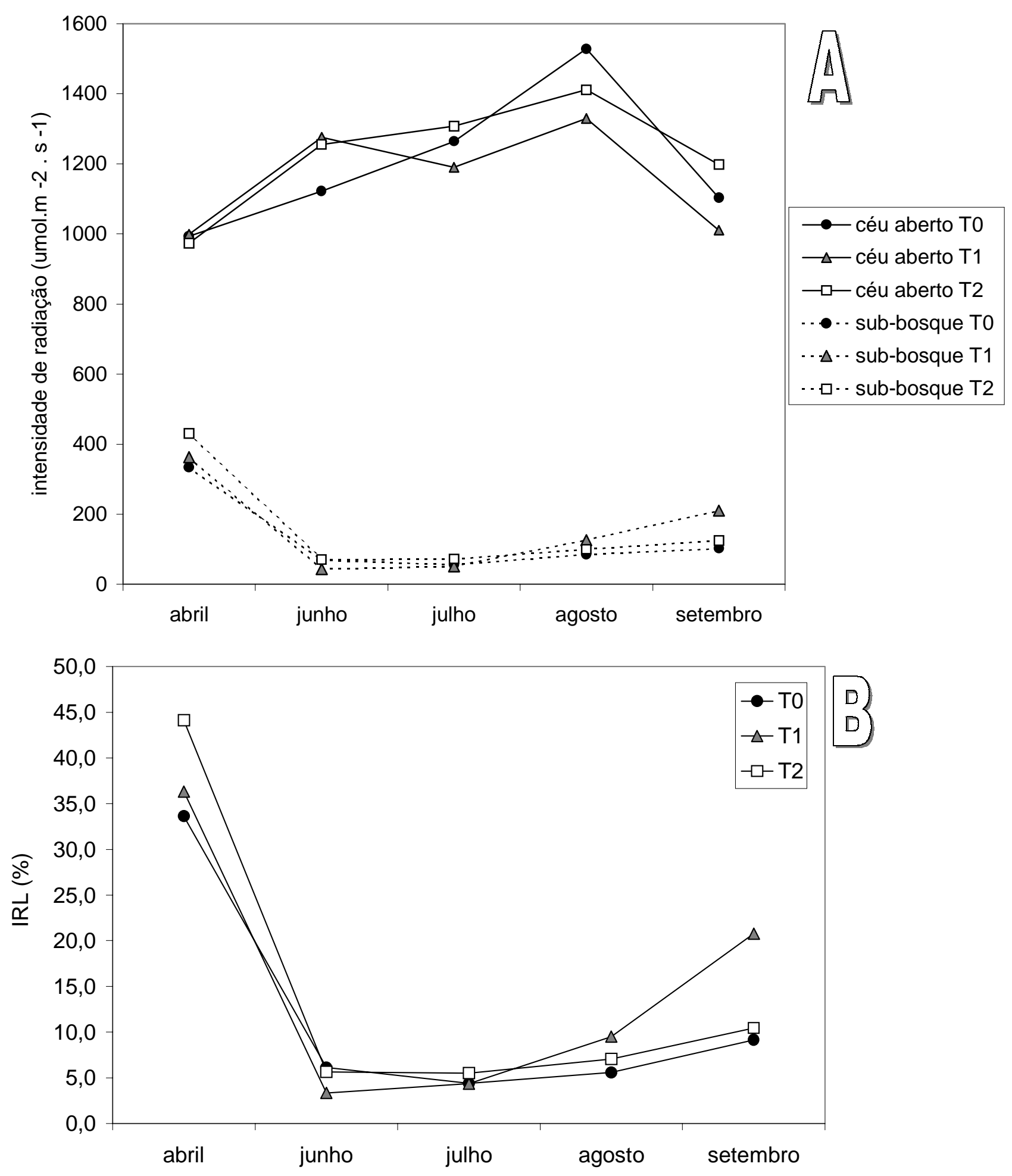

Figura 5. A) Intensidade de radiação $\left(\mu \mathrm{mol} \mathrm{m} \mathrm{m}^{-2} \cdot \mathrm{s}^{-1}\right)$ dentro e fora do povoamento florestal. B) Índice de Luminosidade Relativa (\%) no sub-bosque. 
Schumacher (1992), ao estudar comparativamente a ciclagem de nutrientes e o microclima em talhões de diferentes espécies de eucalipto, realizou medições de luminosidade. As medições foram realizadas em um dia de verão e um dia de inverno, dias de sol e sem nuvens, às $13 \mathrm{~h}$, dentro e fora dos talhões de Eucalyptus camaldulensis, E. grandis e E. torelliana, a fim de calcular o índice relativo de luminosidade (IRL). Também foi determinada a radiação global dentro e fora dos talhões, com o auxílio de um milivoltímetro digital e portátil acoplado a um tubo solarímetro, a $80 \mathrm{~cm}$ de altura, realizada a partir de medições às 9:00, 12:00 e 15:00 h. $\mathrm{O}$ autor verificou que o E. camaldulensis foi a espécie que interceptou as menores quantidades percentuais da radiação total externa incidente sobre a floresta, tanto no verão como no inverno. Esta espécie também apresentou os maiores valores de IRL. Em ambos os casos o autor explicou este comportamento pela menor densidade de plantio desta espécie, e pela estrutura da copa onde os ramos e as folhas são pendentes, propiciando uma maior passagem da radiação solar para o interior do povoamento.

\subsubsection{Temperatura do ar}

Segundo Pardé (1974), a temperatura do ar sob cobertura florestal tem um comportamento similar ao da radiação solar, que fornece energia para o ar, a vegetação e a superfície do solo. Para conhecer a influência da floresta sobre a temperatura do ar, estuda-se as temperaturas máximas e mínimas no decorrer dos meses.

As temperaturas máximas, médias e mínimas mensais, no período de abril a outubro de 1999, são apresentadas na Figura 6.

Dentre os meses avaliados, as temperatura máximas ocorreram em setembro (T2) e outubro (T0 e T1). Em outubro, a temperatura máxima chegou aos $39^{\circ} \mathrm{C}$, no tratamento sem desbaste. No T2, as temperaturas máximas estiveram cerca de $2^{\circ} \mathrm{C}$ acima dos demais tratamentos.

As temperaturas mínimas não variaram muito entre os tratamentos, e os menores valores foram encontrados em abril e agosto. A temperatura mínima do período, de $6^{\circ} \mathrm{C}$, foi medida no $\mathrm{T} 2$. 


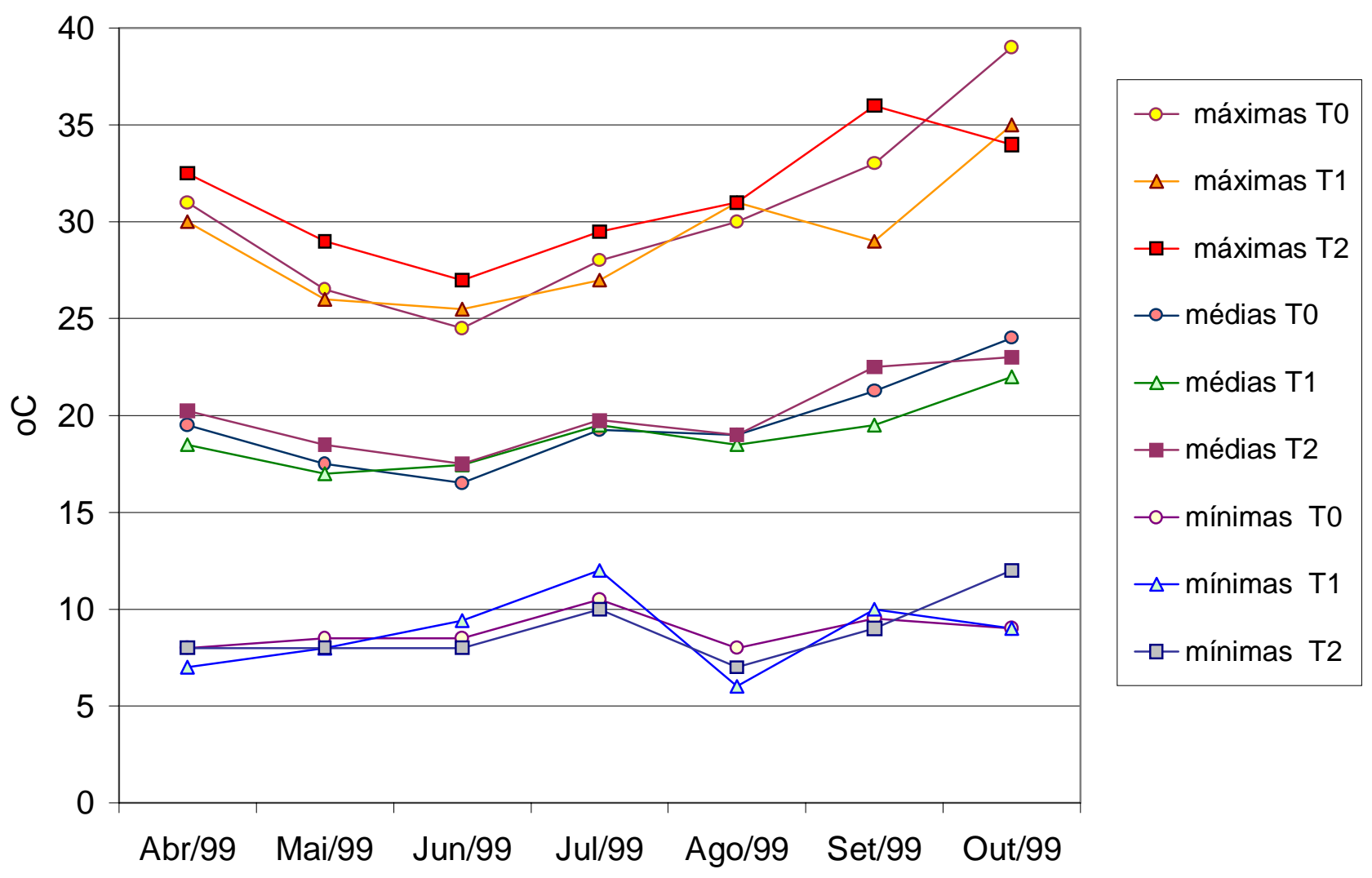

Figura 6. Temperaturas máximas, médias e mínimas mensais ( $\left.{ }^{\circ} \mathrm{C}\right)$ nos três tratamentos.

No T2, de um modo geral, foram registradas as maiores temperaturas médias no período, com exceção do mês de outubro, em que o T0 apresentou as maiores temperaturas médias. Porém, as diferenças de temperatura média mensal entre os tratamentos foi muito pequena.

É importante salientar que o tratamento com maior intensidade de desbaste (T2) apresentou maior amplitude térmica, com as maiores temperaturas máximas e as menores temperaturas mínimas, provavelmente devido à sua maior exposição ao sol e aos ventos. Isto corrobora os resultados de Jacobs (1988), segundo o qual o dossel arbóreo, a vegetação de sub-bosque e a serapilheira reduzem os extremos de temperatura pela interceptação de ondas longas de radiação. 


\subsubsection{Umidade do solo}

Os resultados de umidade do solo nas profundidades de 0 a $5 \mathrm{~cm}, 6$ a $30 \mathrm{~cm}$, e 31 a $60 \mathrm{~cm}$ são apresentados, respectivamente, nas figuras 7A, 7B e 7C.

Ao longo do período de avaliação, todos os tratamentos tiveram curvas de umidade similares. As exceções ocorreram no mês de maio, para a profundidade de 0-5 $\mathrm{cm}$, e o mês de abril, para as demais profundidades.

Verificou-se que os desbastes realizados nos tratamentos $\mathrm{T} 1$ e $\mathrm{T} 2$ interferem na umidade do solo. $\mathrm{O}$ tratamento sem desbastes apresentou o maior teor de umidade em todas as profundidades, ao longo do período de avaliação, sendo muito superior aos tratamentos T1 e T2, com exceção do mês de abril.

Os maiores teores de umidade no T0 indicam que, apesar do maior número de árvores por hectare, a evapotranspiração neste povoamento não deve ser tão intensa quanto nos tratamentos com desbastes. A menor incidência de luz e o acúmulo de uma camada maior de serapilheira, neste tratamento, podem auxiliar na conservação da umidade do solo. Ao contrário, os povoamentos desbastados possuem maior espaçamento e continuam em crescimento, consumindo maiores quantidades de água.

Ashton (1992), ao estudar clareiras de diferentes tamanhos, coletou amostras de solo dos primeiros $5 \mathrm{~cm}$, em uma floresta tropical pluvial no Sri Lanka, determinando o conteúdo de umidade gravimetricamente, pela secagem a $105^{\circ} \mathrm{C}$ por $12 \mathrm{~h}$. O centro das clareiras nas três posições (vale, meia encosta e topo da montanha) apresentaram menores quantidades de água na superfície do solo do que nas áreas adjacentes, sob o dossel florestal. Segundo o autor, o fato da umidade do solo ser quase sempre maior sob o dossel, que no centro de clareiras, indica que o sombreamento deixa a camada superficial mais úmida, apesar da evapotranspiração arbórea. Porém, se a evapotranspiração for intensa, a umidade do solo sob o dossel poderá ser inferior à umidade nas clareiras, especialmente nas camadas mais profundas. 

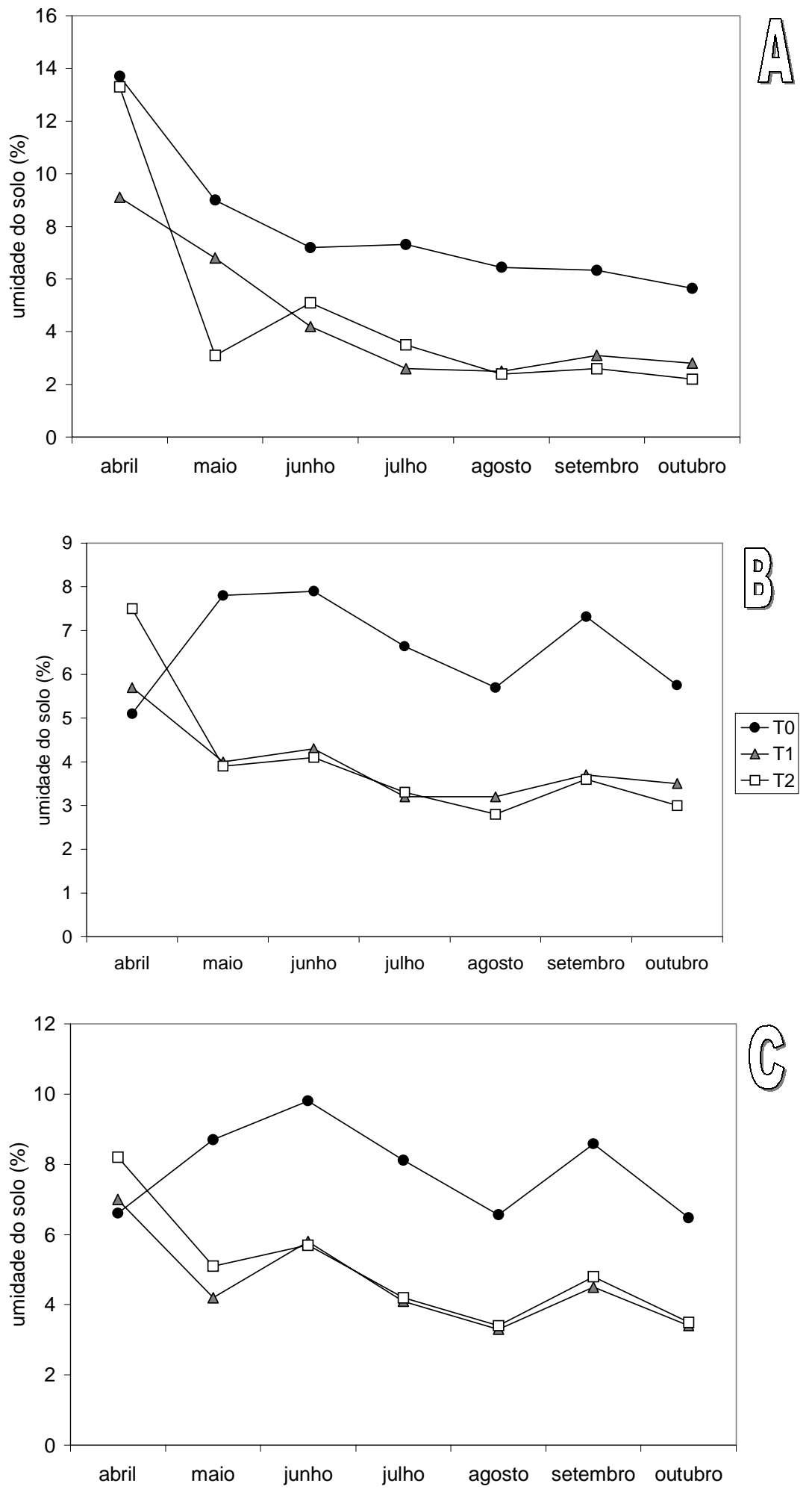

Figura 7. Umidade do solo em porcentagem. A) 0 a $5 \mathrm{~cm}$ de profundidade. B) 6 a 30 $\mathrm{cm}$ de profundidade. C) $31 \mathrm{a} 60 \mathrm{~cm}$ de profundidade. 


\subsection{Produção mensal de serapilheira}

Não se observou diferença estatística na produção mensal de serapilheira entre os tratamentos estudados (Figura 8 e Tabela 4), com exceção dos meses de Outubro de 1998, Julho, Agosto e Setembro de 1999 (primavera e final do inverno).

Apesar das variações mensais apresentadas na Figura 8, a deposição anual de serapilheira dos três tratamentos não diferiu estatisticamente (Figura 9).

Segundo Bray \& Gorham (1964), em povoamentos puros, as taxas de deposição de material orgânico têm mostrado maior relação com a área basal do que com o número de árvores por hectare. Eles afirmam que, quando um povoamento fechado é desbastado, há um decréscimo na deposição de material orgânico aproximadamente proporcional ao grau de desbaste.

Entretanto, este não foi o caso dos tratamentos do CCT. Talvez esta redução na deposição da serapilheira possa ter ocorrido logo após a realização dos desbastes, aos 7 anos. Como os povoamentos já estavam com cerca de 20 anos, no período desta avaliação, o efeito não pôde ser observado.

A produção anual de serapilheira nos tratamentos T0, T1 e T2 foi de 10,2, 10,9 e 10,4 t/ha/ano, respectivamente. Estes resultados foram semelhantes aos encontrados na Austrália por Turner \& Lambert (1983) em florestas de E. saligna adulto (10,0 t/ha/ano) e E. grandis aos 27 anos (9,6 t/ha/ano).

Carpanezzi (1980) acompanhou a deposição de material orgânico e nutrientes em uma floresta natural e em uma plantação de Eucalyptus grandis com 5 anos, no interior do estado de São Paulo. Observou que a mata natural depositou 10,5 t/ha/ano de detritos, e o eucaliptal, 7,5 t/ha/ano.

Schumacher (1992), em Anhembi (SP), encontrou os seguintes valores de deposição de folhedo: Eucalyptus camaldulensis (aos 7 anos), 7,2 t/ha/ano; E. grandis (aos 7 anos), 3,1 t/ha/ano; E. torelliana (aos 10 anos), 5,9 t/ha/ano. Os valores encontrados por Schumacher (1992) são menores do que os encontrados neste trabalho, pois referem-se apenas à fração folhas da serapilheira. Além disso, o autor estudou povoamentos mais jovens. 
De acordo com Gonzales \& Gallardo (1982), a taxa de deposição de resíduos de uma determinada espécie modifica-se com a fase de desenvolvimento da planta ou do ecossistema florestal. Os autores supõem que ocorram aumentos na produção de serapilheira em função do aumento na idade da floresta, até que esta atinja a maturidade ou o clímax.

De novembro a março, que coincide com o período quente e chuvoso, foi observada a maior deposição de serapilheira, em todos os tratamentos. Neste período de cinco meses, nos tratamentos T0, T1 e T2, ocorreram, respectivamente, a queda de $60 \%, 67 \%$ e $69 \%$ de toda a serapilheira depositada durante o ano de estudo.

Segundo Poggiani (1985), na fase de elevação da temperatura, ao final da primavera e durante o verão, haveria maior brotação e crescimento de folhas novas, à custa dos nutrientes e hormônios antes translocados às folhas adultas. De acordo com Street \& Öpik (1974), durante a fase de desenvolvimento, quando os diferentes órgãos entram em competição por nutrientes, o crescimento de um órgão pode resultar na senescência e morte de um outro. Assim, o eucalipto derrubaria suas folhas, não devido a problemas de suprimento hídrico, como a maioria das espécies nativas do interior do Estado de São Paulo, mas em função da translocação de compostos orgânicos e nutrientes das folhas adultas para as folhas novas em fase de crescimento, o que ocorreria na primavera e verão, épocas de maior renovação de folhas.

Em Novembro, foram observados as maiores valores de deposição de serapilheira nos tratamentos T0 e T1. Para o T2, o pico de deposição ocorreu mais tarde, no mês de Dezembro. Embora não tenha sido feita a separação da serapilheira em diferentes frações (folhas, ramos, casca, miscelânea), verificou-se, nestes meses, uma intensa deposição de casca. Entretanto, esta deposição de casca não ocorreu de forma regular entre os coletores, e ocasionou a alta produção de serapilheira nestes meses. Como a deposição de casca é mais acentuada nas proximidades da base do caule, as bandejas tradicionais, dispostas ao acaso ou sistematicamente, são inadequadas para a medição. Para evitar um ao alto coeficiente de variação entre as bandejas, nas coletas de casca, seriam mais recomendadas bandejas que circundam o caule. 


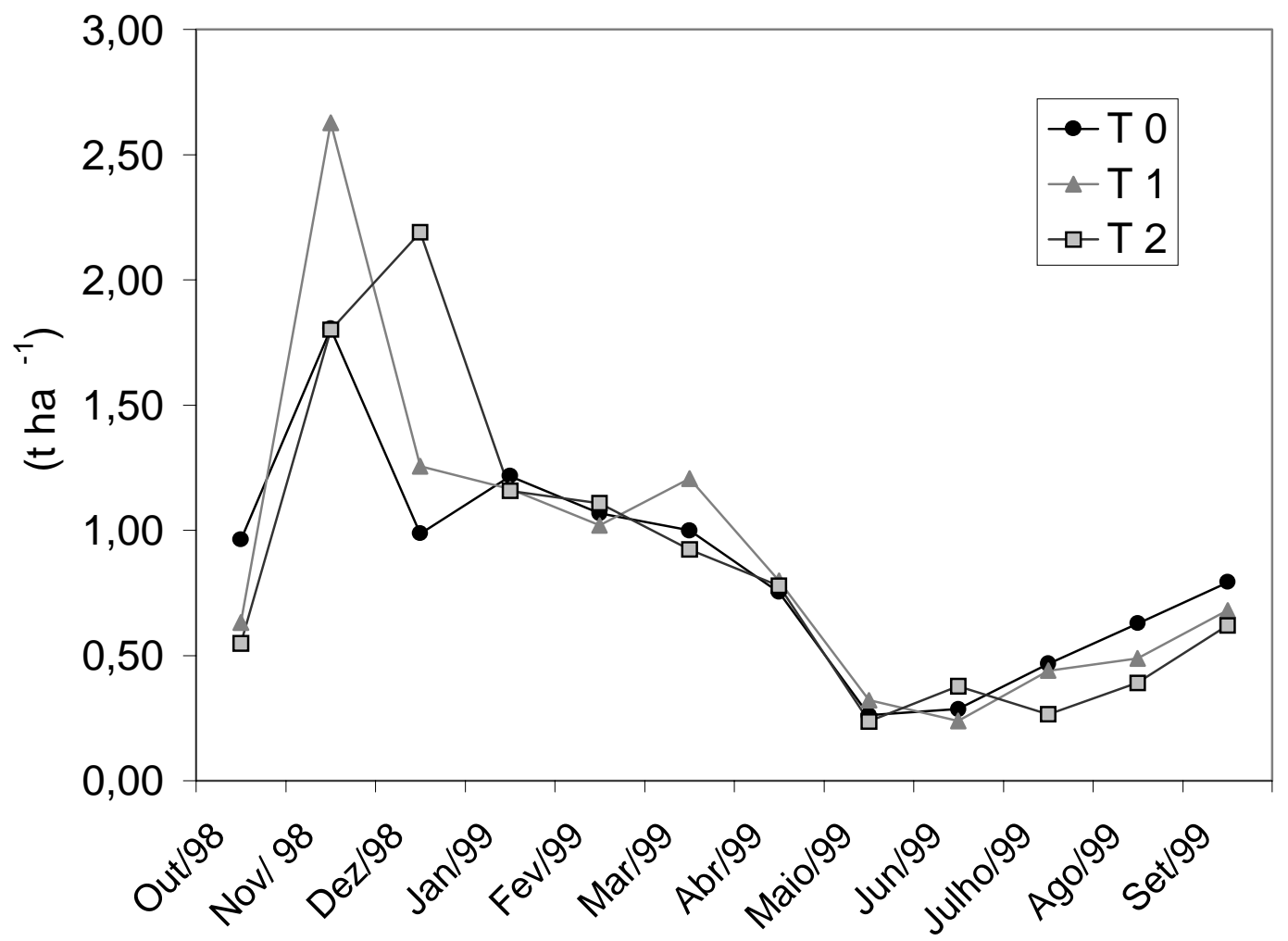

Figura 8. Deposição mensal de serapilheira (outubro 1998 a setembro de 1999).

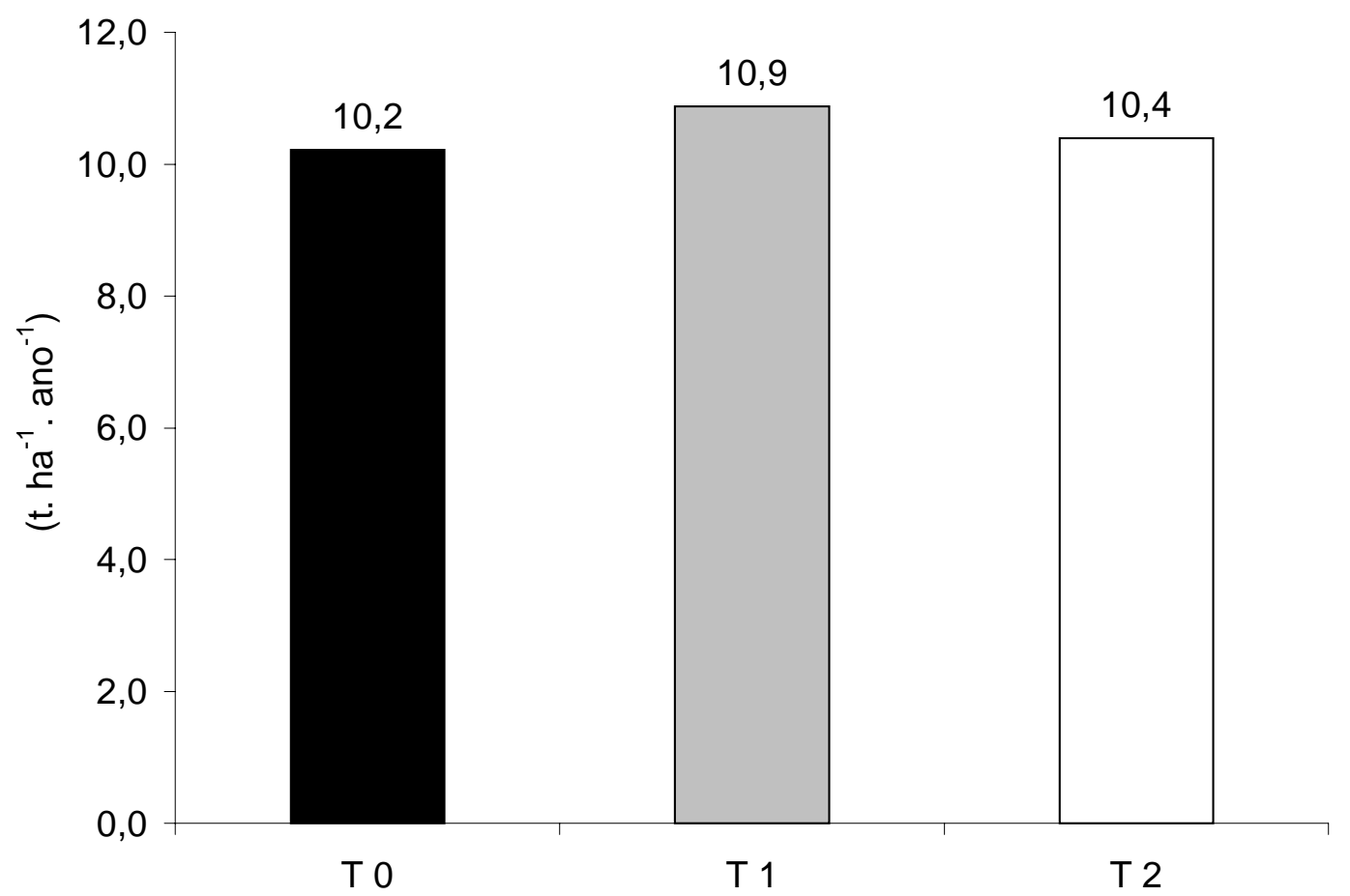

Figura 9. Deposição anual de serapilheira (outubro 1998 a setembro de 1999). 
O período de menor deposição de serapilheira ocorreu na época fria e seca, de Maio a Julho, independente do tratamento.

Estes resultados concordam com os de Carpanezzi (1980), que verificou, em plantações de E. saligna com 5 anos, a maior deposição de material orgânico e de nutrientes no final da primavera e do verão, períodos quentes e chuvosos (meses de dezembro a fevereiro). O mesmo foi observado por Poggiani (1985) em plantios de $E$. saligna entre 7 e 10 anos de idade e por Schumacher (1992), em plantios de E. grandis de 7 anos. Schumacher (1992) também verificou que a menor deposição de folhedo ocorreu na primavera.

\subsection{Concentrações de macronutrientes na serapilheira depositada}

As concentrações dos macronutrientes analisados na serapilheira depositada mensalmente nos coletores foram, em geral, semelhantes nos três tratamentos estudados (tabela 3). Nos meses em que houve diferenças estatísticas entre os tratamentos, em geral os povoamentos desbastados (T1 e T2) apresentaram as maiores concentrações químicas de nutrientes na serapilheira (Figura 10).

O Potássio foi o macronutriente que apresentou maiores variações de concentração, ao longo do ano (Figura 10C). Foram registradas diferenças estatísticas em 8 dos 12 meses (Outubro, Novembro e Dezembro de 1998 e Fevereiro, Março, Abril, Julho e Agosto de 1999), pois este é um nutrientes muito móvel. As concentrações de $\mathrm{K}$ foram superiores no período compreendido entre Abril e Agosto. Estas maiores concentrações no período seco (inverno) podem ser explicadas pelo menor crescimento e, conseqüentemente, menor necessidade de $\mathrm{K}$ nesta época do ano, o que reduz a translocação deste elemento. As menores concentrações deste nutriente ocorreram no mês de dezembro, para todos os tratamentos. No período quente e úmido, há uma maior taxa de crescimento e de utilização do K, e ocorre uma alta translocação das folhas velhas e senescentes para as folhas novas, o que explica sua baixa concentração na serapilheira depositada durante o verão. 
Tabela 3. Concentração dos macronutrientes $\left(\mathrm{g} \cdot \mathrm{kg}^{-1}\right)$ contidos na serapilheira produzida nos tratamentos com diferentes intensidades de desbaste, de outubro de 1998 a setembro de 1999 .

\begin{tabular}{|c|c|c|c|c|c|c|c|}
\hline Mês & Trat. & $\mathrm{N}$ & $\mathrm{P}$ & $\mathrm{K}$ & $\mathrm{Ca}$ & $\mathrm{Mg}$ & $S$ \\
\hline \multirow[t]{3}{*}{ Out. } & T0 & $7,83 \mathrm{~b}$ & $0,35 \mathrm{a}$ & $0,90 \mathrm{c}$ & $8,70 \mathrm{a}$ & $2,86 \mathrm{~b}$ & $0,67 \mathrm{a}$ \\
\hline & $\mathrm{T} 1$ & $8,03 \mathrm{ab}$ & $0,33 \mathrm{a}$ & $1,41 \mathrm{~b}$ & $9,66 \mathrm{a}$ & $2,84 \mathrm{~b}$ & $0,74 \mathrm{a}$ \\
\hline & $\mathrm{T} 2$ & $9,17 \mathrm{a}$ & $0,34 \mathrm{a}$ & $1,67 \mathrm{a}$ & $8,86 \mathrm{a}$ & $3,20 \mathrm{a}$ & $0,77 \mathrm{a}$ \\
\hline \multirow[t]{3}{*}{ Nov. } & T0 & $6,93 \mathrm{a}$ & $0,31 \mathrm{a}$ & $1,63 \mathrm{~b}$ & $8,64 \mathrm{a}$ & $3,00 \mathrm{~b}$ & $0,67 \mathrm{a}$ \\
\hline & $\mathrm{T} 1$ & $5,80 \mathrm{a}$ & $0,26 \mathrm{a}$ & $1,89 \mathrm{~b}$ & $7,51 \mathrm{a}$ & $3,00 \mathrm{~b}$ & $0,59 \mathrm{a}$ \\
\hline & $\mathrm{T} 2$ & $7,34 \mathrm{a}$ & $0,31 \mathrm{a}$ & $3,21 \mathrm{a}$ & $7,64 \mathrm{a}$ & $3,46 \mathrm{a}$ & $0,66 \mathrm{a}$ \\
\hline \multirow[t]{3}{*}{ Dez } & T0 & $7,20 \mathrm{a}$ & $0,30 \mathrm{a}$ & $0,69 \mathrm{~b}$ & $7,89 \mathrm{a}$ & $2,51 \mathrm{a}$ & $0,43 \mathrm{a}$ \\
\hline & $\mathrm{T} 1$ & $7,26 \mathrm{a}$ & $0,29 \mathrm{a}$ & $0,90 \mathrm{ab}$ & $6,81 \mathrm{a}$ & $2,66 \mathrm{a}$ & $0,46 \mathrm{a}$ \\
\hline & $\mathrm{T} 2$ & $6,31 \mathrm{a}$ & $0,26 \mathrm{a}$ & $1,20 \mathrm{a}$ & $6,20 \mathrm{a}$ & $2,61 \mathrm{a}$ & $0,47 \mathrm{a}$ \\
\hline \multirow[t]{3}{*}{ Jan. } & T0 & $6,46 \mathrm{a}$ & $0,27 \mathrm{a}$ & $1,71 \mathrm{a}$ & $7,60 \mathrm{a}$ & $2,52 \mathrm{a}$ & $0,56 \mathrm{~b}$ \\
\hline & $\mathrm{T} 1$ & $7,86 \mathrm{a}$ & $0,31 \mathrm{a}$ & $2,19 \mathrm{a}$ & $7,11 \mathrm{a}$ & $2,54 \mathrm{a}$ & $0,71 \mathrm{a}$ \\
\hline & $\mathrm{T} 2$ & $8,21 \mathrm{a}$ & $0,29 \mathrm{a}$ & $2,49 \mathrm{a}$ & $6,94 \mathrm{a}$ & $2,51 \mathrm{a}$ & $0,71 \mathrm{a}$ \\
\hline \multirow[t]{3}{*}{ Fev. } & T0 & $6,64 \mathrm{~b}$ & $0,23 \mathrm{~b}$ & $1,24 \mathrm{~b}$ & $8,27 \mathrm{a}$ & $1,67 \mathrm{a}$ & $0,31 \mathrm{a}$ \\
\hline & $\mathrm{T} 1$ & $8,50 \mathrm{a}$ & $0,36 \mathrm{a}$ & $1,63 \mathrm{a}$ & $8,29 \mathrm{a}$ & $1,86 \mathrm{a}$ & $0,50 \mathrm{a}$ \\
\hline & $\mathrm{T} 2$ & $6,59 \mathrm{~b}$ & $0,21 \mathrm{~b}$ & $1,50 \mathrm{a}$ & $7,57 \mathrm{a}$ & $1,79 \mathrm{a}$ & $0,34 \mathrm{a}$ \\
\hline \multirow[t]{3}{*}{ Mar } & $\mathrm{T} 0$ & 7,01 a & $0,23 \mathrm{a}$ & $1,59 \mathrm{~b}$ & $7,40 \mathrm{a}$ & $1,76 \mathrm{a}$ & $0,41 \mathrm{a}$ \\
\hline & $\mathrm{T} 1$ & $7,14 \mathrm{a}$ & $0,29 \mathrm{a}$ & $1,71 \mathrm{ab}$ & $7,70 \mathrm{a}$ & $1,67 \mathrm{a}$ & $0,40 \mathrm{a}$ \\
\hline & $\mathrm{T} 2$ & $8,03 \mathrm{a}$ & $0,23 \mathrm{a}$ & $1,97 \mathrm{a}$ & $6,89 \mathrm{a}$ & $1,81 \mathrm{a}$ & $0,49 \mathrm{a}$ \\
\hline \multirow[t]{3}{*}{ Abr. } & T0 & $9,36 \mathrm{a}$ & $0,34 \mathrm{a}$ & $2,49 \mathrm{~b}$ & $7,36 \mathrm{a}$ & $1,84 \mathrm{a}$ & $0,59 \mathrm{a}$ \\
\hline & $\mathrm{T} 1$ & 7,67 a & $0,36 \mathrm{a}$ & $3,04 \mathrm{ab}$ & $6,91 \mathrm{a}$ & $1,84 \mathrm{a}$ & $0,57 \mathrm{a}$ \\
\hline & $\mathrm{T} 2$ & $8,60 \mathrm{a}$ & $0,39 \mathrm{a}$ & $3,30 \mathrm{a}$ & $6,69 \mathrm{a}$ & $2,07 \mathrm{a}$ & $0,60 \mathrm{a}$ \\
\hline \multirow[t]{3}{*}{ Maio } & T0 & $8,19 \mathrm{a}$ & $0,31 \mathrm{a}$ & $3,34 \mathrm{a}$ & $6,90 \mathrm{a}$ & $1,89 \mathrm{a}$ & $0,83 \mathrm{a}$ \\
\hline & $\mathrm{T} 1$ & $8,49 \mathrm{a}$ & $0,33 \mathrm{a}$ & $4,59 \mathrm{a}$ & $7,27 \mathrm{a}$ & $2,06 \mathrm{a}$ & $0,90 \mathrm{a}$ \\
\hline & $\mathrm{T} 2$ & $8,33 \mathrm{a}$ & $0,33 \mathrm{a}$ & $4,89 \mathrm{a}$ & $5,91 \mathrm{a}$ & $1,91 \mathrm{a}$ & $0,77 \mathrm{a}$ \\
\hline \multirow[t]{3}{*}{ Jun. } & T0 & $8,63 \mathrm{a}$ & $0,30 \mathrm{a}$ & $2,40 \mathrm{a}$ & $7,73 \mathrm{~b}$ & $1,67 \mathrm{~b}$ & $0,61 \mathrm{a}$ \\
\hline & $\mathrm{T} 1$ & $9,53 \mathrm{a}$ & $0,40 \mathrm{a}$ & $2,74 \mathrm{a}$ & $10,20 \mathrm{a}$ & $2,16 \mathrm{a}$ & $0,81 \mathrm{a}$ \\
\hline & $\mathrm{T} 2$ & $8,13 \mathrm{a}$ & $0,33 \mathrm{a}$ & $2,36 \mathrm{a}$ & $7,46 \mathrm{~b}$ & $1,83 \mathrm{ab}$ & $0,59 \mathrm{a}$ \\
\hline \multirow[t]{3}{*}{ Jul. } & T0 & $7,36 \mathrm{a}$ & $0,24 \mathrm{a}$ & $3,69 \mathrm{~b}$ & $8,56 \mathrm{ab}$ & $1,74 \mathrm{~b}$ & $0,61 \mathrm{a}$ \\
\hline & $\mathrm{T} 1$ & 7,91 a & $0,29 \mathrm{a}$ & $4,46 \mathrm{a}$ & $9,17 \mathrm{a}$ & $2,09 \mathrm{a}$ & $0,71 \mathrm{a}$ \\
\hline & $\mathrm{T} 2$ & $8,07 \mathrm{a}$ & $0,30 \mathrm{a}$ & $4,97 \mathrm{a}$ & $7,51 \mathrm{~b}$ & $2,19 \mathrm{a}$ & $0,70 \mathrm{a}$ \\
\hline \multirow[t]{3}{*}{ Ago. } & T0 & $6,54 \mathrm{~b}$ & $0,21 \mathrm{~b}$ & $3,64 \mathrm{c}$ & $7,06 \mathrm{a}$ & $1,67 \mathrm{a}$ & $0,60 \mathrm{a}$ \\
\hline & $\mathrm{T} 1$ & 7,79 a & $0,26 \mathrm{ab}$ & $4,63 \mathrm{~b}$ & $7,14 \mathrm{a}$ & $1,73 \mathrm{a}$ & $0,74 \mathrm{a}$ \\
\hline & $\mathrm{T} 2$ & 7,91 a & $0,30 \mathrm{a}$ & $5,83 \mathrm{a}$ & $6,83 \mathrm{a}$ & $1,84 \mathrm{a}$ & $0,76 \mathrm{a}$ \\
\hline \multirow[t]{3}{*}{ Set. } & T0 & $8,01 \mathrm{a}$ & $0,46 \mathrm{a}$ & $1,97 \mathrm{a}$ & $7,60 \mathrm{ab}$ & $1,83 \mathrm{a}$ & $0,63 \mathrm{a}$ \\
\hline & $\mathrm{T} 1$ & $8,44 \mathrm{a}$ & $0,34 \mathrm{ab}$ & $2,06 \mathrm{a}$ & $8,27 \mathrm{a}$ & $2,01 \mathrm{a}$ & $0,71 \mathrm{a}$ \\
\hline & $\mathrm{T} 2$ & $8,73 \mathrm{a}$ & $0,30 \mathrm{~b}$ & $2,53 \mathrm{a}$ & $6,31 \mathrm{~b}$ & $1,83 \mathrm{a}$ & $0,57 \mathrm{a}$ \\
\hline
\end{tabular}

Médias seguidas de mesma letra não diferem entre si pelo teste de Tukey a $5 \%$ de probabilidade. 

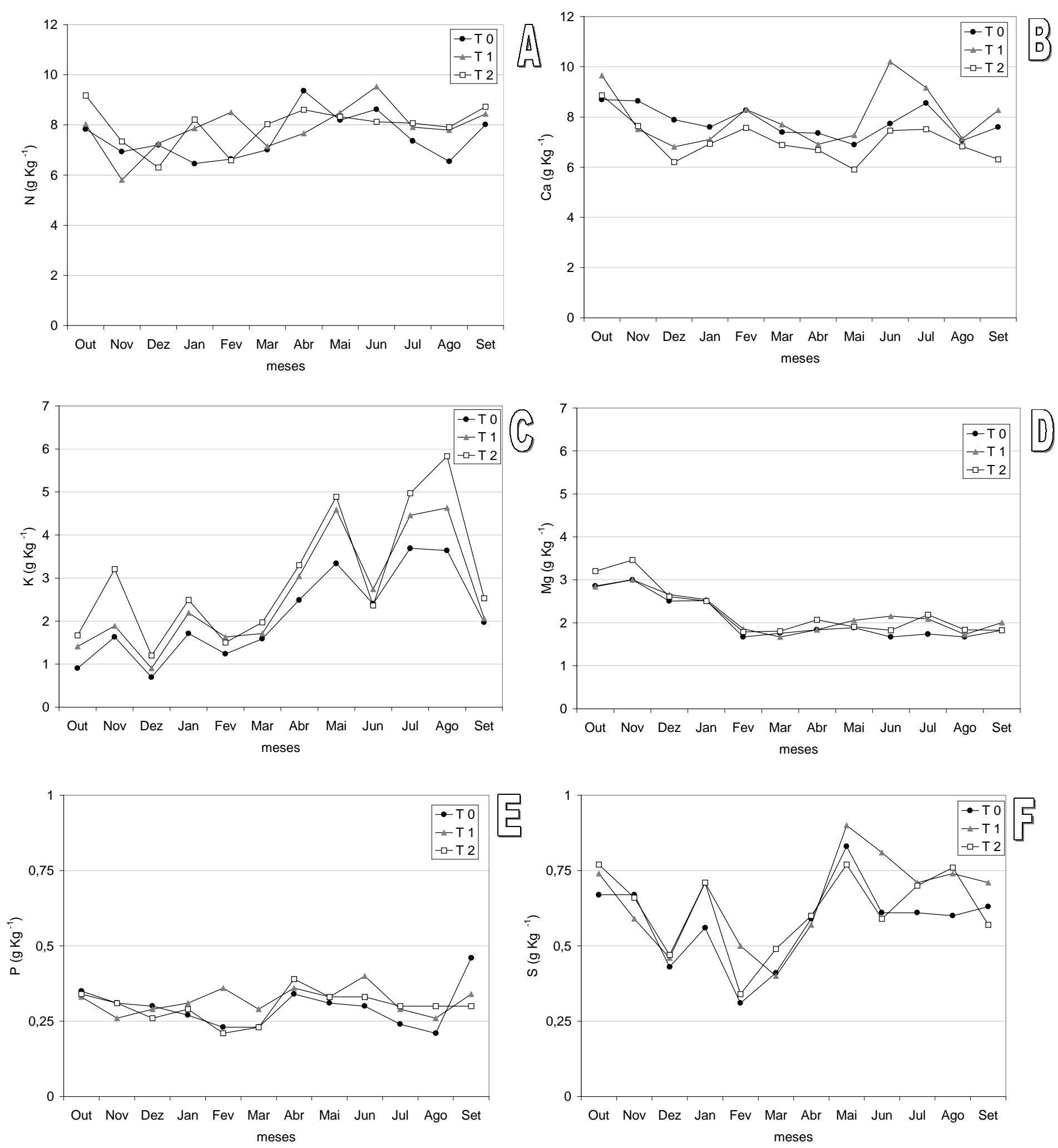

Figura 10. Variação mensal da concentração de macronutrientes na serapilheira produzida $\left(\mathrm{g} \mathrm{Kg}^{-1}\right)$ A) Nitrogênio; B) Cálcio; C) Potássio; D) Magnésio; E) Fósforo; F) Enxofre. 
$\mathrm{O} \mathrm{K}$ foi também o nutriente que mais demonstrou sofrer a influência dos desbastes, formando visivelmente 3 níveis de concentrações. As concentrações de K na serapilheira produzida mensalmente foram proporcionais às intensidades de desbaste: em geral, a testemunha (T0) apresentou as menores concentrações, e o T2 (maior intensidade de desbaste), as maiores.

\subsection{Transferência mensal e anual de macronutrientes via serapilheira}

A transferência de nutrientes via serapilheira foi semelhante entre os tratamentos na maioria dos meses avaliados (Tabelas 4 e 5). Em geral, quando houve diferença estatística entre os tratamentos, destacaram-se os tratamentos onde foram realizados os desbastes. As exceções foram os meses de outubro 1997, agosto e setembro de 1998, em que o povoamento não desbastado depositou maiores quantias de macronutrientes ao solo. A transferência de nutrientes ao solo foi determinada pela sazonalidade verificada na produção de serapilheira. A maior deposição de nutrientes ocorreu, em geral, no período de novembro a março, e a menor, de maio a julho.

No mês de outubro, com exceção do $\mathrm{K}$, os demais macronutrientes foram depositados em maior quantidade no tratamento testemunha, pois a deposição de serapilheira, neste mês, foi cerca de 50\% maior que nos tratamentos com desbaste.

Deve-se ressaltar, porém, que a maior deposição mensal de serapilheira não necessariamente significou uma maior transferência de macronutrientes ao solo. Vários meses em que não houve diferença na deposição de serapilheira (Novembro de 1998 a Março de 1999), houve diferença significativa entre tratamentos quanto à deposição dos nutrientes, em virtude das variações nas concentrações destes elementos. 
Tabela 4. Deposição mensal de serapilheira $\left(\mathrm{t} \cdot \mathrm{ha}^{-1}\right)$ e macronutrientes $\left(\mathrm{kg} \cdot \mathrm{ha}^{-1}\right)$, nos três tratamentos, no período de estudo (outubro de 1998 a setembro de 1999).

\begin{tabular}{|c|c|c|c|c|c|c|c|c|}
\hline Mês & Trat. & Serapilheira $\left(\mathrm{t} \mathrm{ha}^{-1}\right)$ & $\mathrm{N}$ & $\mathrm{P}$ & $\mathrm{K}$ & $\mathrm{Ca}$ & $\mathrm{Mg}$ & $\mathrm{S}$ \\
\hline \multirow[t]{3}{*}{ Out. } & T0 & 0,96 & $7,39 \mathrm{a}$ & $0,34 \mathrm{a}$ & $0,87 \mathrm{a}$ & $8,29 \mathrm{a}$ & $2,74 \mathrm{a}$ & $0,63 \mathrm{a}$ \\
\hline & $\mathrm{T} 1$ & 0,63 & $5,09 \mathrm{~b}$ & $0,22 \mathrm{~b}$ & $0,90 \mathrm{a}$ & $6,12 \mathrm{~b}$ & $1,80 \mathrm{~b}$ & $0,46 \mathrm{~b}$ \\
\hline & $\mathrm{T} 2$ & 0,55 & $4,66 \mathrm{~b}$ & $0,20 \mathrm{~b}$ & $0,93 \mathrm{a}$ & $4,87 \mathrm{~b}$ & $1,74 \mathrm{~b}$ & $0,42 \mathrm{~b}$ \\
\hline \multirow[t]{3}{*}{ Nov. } & T0 & 1,80 & $12,23 \mathrm{a}$ & $0,55 \mathrm{a}$ & $2,91 \mathrm{~b}$ & $15,31 \mathrm{a}$ & $5,38 \mathrm{a}$ & $1,18 \mathrm{a}$ \\
\hline & $\mathrm{T} 1$ & 2,63 & $14,40 \mathrm{a}$ & $0,67 \mathrm{a}$ & $4,92 \mathrm{ab}$ & $18,31 \mathrm{a}$ & $7,80 \mathrm{a}$ & $1,47 \mathrm{a}$ \\
\hline & T2 & 1,80 & $13,03 \mathrm{a}$ & $0,54 \mathrm{a}$ & $5,70 \mathrm{a}$ & $13,51 \mathrm{a}$ & $6,18 \mathrm{a}$ & $1,15 \mathrm{a}$ \\
\hline \multirow[t]{3}{*}{ Dez } & T0 & 0,99 & $7,00 \mathrm{~b}$ & $0,30 \mathrm{a}$ & $0,67 \mathrm{~b}$ & $7,61 \mathrm{a}$ & $2,44 \mathrm{~b}$ & $0,41 \mathrm{~b}$ \\
\hline & $\mathrm{T} 1$ & 1,25 & $8,35 \mathrm{ab}$ & $0,35 \mathrm{a}$ & $1,08 \mathrm{~b}$ & $8,07 \mathrm{a}$ & $3,38 \mathrm{ab}$ & $0,53 \mathrm{~b}$ \\
\hline & $\mathrm{T} 2$ & 2,19 & $12,11 \mathrm{a}$ & $0,50 \mathrm{a}$ & $2,11 \mathrm{a}$ & $12,06 \mathrm{a}$ & $5,48 \mathrm{a}$ & $0,87 \mathrm{a}$ \\
\hline \multirow[t]{3}{*}{ Jan. } & T0 & 1,22 & $7,52 \mathrm{a}$ & $0,26 \mathrm{a}$ & $1,65 \mathrm{~b}$ & $7,41 \mathrm{a}$ & $2,48 \mathrm{~b}$ & $0,55 \mathrm{~b}$ \\
\hline & $\mathrm{T} 1$ & 1,16 & $8,88 \mathrm{a}$ & $0,40 \mathrm{a}$ & $2,87 a b$ & $8,92 \mathrm{a}$ & $3,22 \mathrm{ab}$ & $0,87 \mathrm{ab}$ \\
\hline & $\mathrm{T} 2$ & 1,16 & $9,36 \mathrm{a}$ & $0,66 \mathrm{a}$ & $5,39 \mathrm{a}$ & $15,13 \mathrm{a}$ & $5,44 \mathrm{a}$ & $1,53 \mathrm{a}$ \\
\hline \multirow[t]{3}{*}{ Fev. } & T0 & 1,07 & $7,04 \mathrm{a}$ & $0,24 \mathrm{~b}$ & $1,32 \mathrm{a}$ & $8,83 \mathrm{a}$ & $1,78 \mathrm{a}$ & $0,33 \mathrm{a}$ \\
\hline & $\mathrm{T} 1$ & 1,02 & $8,63 \mathrm{a}$ & $0,33 \mathrm{a}$ & $1,66 \mathrm{a}$ & $8,44 \mathrm{a}$ & $1,90 \mathrm{a}$ & $0,51 \mathrm{a}$ \\
\hline & $\mathrm{T} 2$ & 1,11 & $7,23 \mathrm{a}$ & $0,23 \mathrm{~b}$ & $1,67 \mathrm{a}$ & $8,32 \mathrm{a}$ & $1,98 \mathrm{a}$ & $0,42 \mathrm{a}$ \\
\hline \multirow[t]{3}{*}{ Mar } & T0 & 1,00 & $6,85 \mathrm{a}$ & $0,23 \mathrm{a}$ & $1,57 \mathrm{a}$ & $7,42 \mathrm{ab}$ & $1,76 \mathrm{a}$ & $0,41 \mathrm{a}$ \\
\hline & $\mathrm{T} 1$ & 1,21 & $8,41 \mathrm{a}$ & $0,31 \mathrm{a}$ & $2,07 \mathrm{a}$ & $8,99 \mathrm{a}$ & $2,00 \mathrm{a}$ & $0,50 \mathrm{a}$ \\
\hline & $\mathrm{T} 2$ & 0,92 & $7,21 \mathrm{a}$ & $0,22 \mathrm{a}$ & $1,81 \mathrm{a}$ & $6,32 \mathrm{~b}$ & $1,65 \mathrm{a}$ & $0,44 \mathrm{a}$ \\
\hline \multirow[t]{3}{*}{ Abr. } & T0 & 0,75 & $6,83 \mathrm{a}$ & $0,25 \mathrm{a}$ & $1,87 \mathrm{a}$ & $5,55 \mathrm{a}$ & $1,37 \mathrm{a}$ & $0,45 \mathrm{a}$ \\
\hline & T1 & 0,80 & $6,11 \mathrm{a}$ & $0,28 \mathrm{a}$ & $2,44 \mathrm{a}$ & $5,50 \mathrm{a}$ & $1,48 \mathrm{a}$ & $0,47 \mathrm{a}$ \\
\hline & $\mathrm{T} 2$ & 0,78 & $6,63 \mathrm{a}$ & $0,32 \mathrm{a}$ & $2,70 \mathrm{a}$ & $5,00 \mathrm{a}$ & $1,59 \mathrm{a}$ & $0,50 \mathrm{a}$ \\
\hline \multirow[t]{3}{*}{ Maio } & T0 & 0,26 & $2,21 \mathrm{a}$ & $0,08 \mathrm{a}$ & $0,88 \mathrm{a}$ & $1,36 \mathrm{a}$ & $0,50 \mathrm{a}$ & $0,17 \mathrm{a}$ \\
\hline & $\mathrm{T} 1$ & 0,32 & $2,78 \mathrm{a}$ & $0,11 \mathrm{a}$ & $1,51 \mathrm{a}$ & $2,44 \mathrm{a}$ & $0,68 \mathrm{a}$ & $0,31 \mathrm{a}$ \\
\hline & $\mathrm{T} 2$ & 0,24 & $1,88 \mathrm{a}$ & $0,07 \mathrm{a}$ & $1,10 \mathrm{a}$ & $1,36 \mathrm{a}$ & $0,43 \mathrm{a}$ & $0,17 \mathrm{a}$ \\
\hline \multirow[t]{3}{*}{ Jun. } & T0 & 0,29 & $2,50 \mathrm{a}$ & $0,09 \mathrm{a}$ & $0,77 \mathrm{a}$ & $2,25 \mathrm{a}$ & $0,48 \mathrm{a}$ & $0,18 \mathrm{a}$ \\
\hline & $\mathrm{T} 1$ & 0,24 & $2,30 \mathrm{a}$ & $0,10 \mathrm{a}$ & $0,69 \mathrm{a}$ & $2,48 \mathrm{a}$ & $0,53 \mathrm{a}$ & $0,20 \mathrm{a}$ \\
\hline & $\mathrm{T} 2$ & 0,38 & $3,60 \mathrm{a}$ & $0,11 \mathrm{a}$ & $0,78 \mathrm{a}$ & $2,49 \mathrm{a}$ & $0,64 \mathrm{a}$ & $0,19 \mathrm{a}$ \\
\hline \multirow[t]{3}{*}{ Jul. } & T0 & 0,47 & $3,38 \mathrm{a}$ & $0,11 \mathrm{a}$ & $1,69 \mathrm{a}$ & $4,04 \mathrm{a}$ & $0,82 \mathrm{a}$ & $0,28 \mathrm{ab}$ \\
\hline & $\mathrm{T} 1$ & 0,44 & $3,53 \mathrm{a}$ & $0,13 \mathrm{a}$ & $1,98 \mathrm{a}$ & $4,03 \mathrm{a}$ & $0,93 \mathrm{a}$ & $0,31 \mathrm{a}$ \\
\hline & $\mathrm{T} 2$ & 0,27 & $2,07 \mathrm{~b}$ & $0,08 \mathrm{a}$ & $1,33 \mathrm{a}$ & $2,00 \mathrm{~b}$ & $0,58 \mathrm{a}$ & $0,18 \mathrm{~b}$ \\
\hline \multirow[t]{3}{*}{ Ago. } & T0 & 0,63 & $4,08 \mathrm{a}$ & $0,13 \mathrm{a}$ & $2,27 \mathrm{a}$ & $4,43 \mathrm{a}$ & $1,05 \mathrm{a}$ & $0,38 \mathrm{a}$ \\
\hline & $\mathrm{T} 1$ & 0,49 & $3,87 \mathrm{a}$ & $0,13 \mathrm{a}$ & $2,31 \mathrm{a}$ & $3,50 \mathrm{~b}$ & $0,85 \mathrm{ab}$ & $0,37 \mathrm{a}$ \\
\hline & $\mathrm{T} 2$ & 0,39 & $3,07 \mathrm{a}$ & $0,12 \mathrm{a}$ & $2,27 \mathrm{a}$ & $2,67 \mathrm{~b}$ & $0,71 \mathrm{~b}$ & $0,29 \mathrm{a}$ \\
\hline \multirow[t]{3}{*}{ Set. } & T0 & 0,79 & $6,35 \mathrm{a}$ & $0,36 \mathrm{a}$ & $1,56 \mathrm{a}$ & $5,99 \mathrm{a}$ & $1,45 \mathrm{a}$ & $0,50 \mathrm{a}$ \\
\hline & $\mathrm{T} 1$ & 0,68 & $5,74 \mathrm{a}$ & $0,23 \mathrm{~b}$ & $1,41 \mathrm{a}$ & $5,72 \mathrm{a}$ & $1,38 \mathrm{a}$ & $0,49 \mathrm{a}$ \\
\hline & $\mathrm{T} 2$ & 0,62 & $5,37 \mathrm{a}$ & $0,18 \mathrm{~b}$ & $1,57 \mathrm{a}$ & $3,90 \mathrm{~b}$ & $1,12 \mathrm{a}$ & $0,35 \mathrm{a}$ \\
\hline
\end{tabular}

Médias seguidas de mesma letra não diferem entre si pelo teste de Tukey a 5\% de probabilidade. 
A transferência anual de nutrientes ao solo ocorreu na ordem: $\mathrm{Ca}>\mathrm{N}>\mathrm{Mg}>\mathrm{K}>\mathrm{S}>\mathrm{P}$, em todos os tratamentos (Figura 11). A transferência de $\mathrm{Ca}+\mathrm{N}$ correspondeu à $70 \%, 73 \%$ e $76 \%$ do total de macronutrientes nos tratamentos T0, T1 e $\mathrm{T} 2$, respectivamente.

Os retornos anuais de $\mathrm{K}$ e $\mathrm{Mg}$ ao solo via serapilheira foram diretamente proporcionais à intensidade de desbaste, ou seja, os menores valores foram encontrados no tratamento sem desbaste (T0), e os maiores, no tratamento com maior intensidade de desbaste (T2). Isto pode ser atribuído ao fato dos tratamentos desbastados apresentarem maiores taxas de decomposição da serapilheira (item 4.7.2) e, consequentemente, uma ciclagem mais rápida destes nutrientes. $\mathrm{O} \mathrm{K}$, particularmente, é um elemento de alta mobilidade nas plantas e nos ecossistemas florestais.

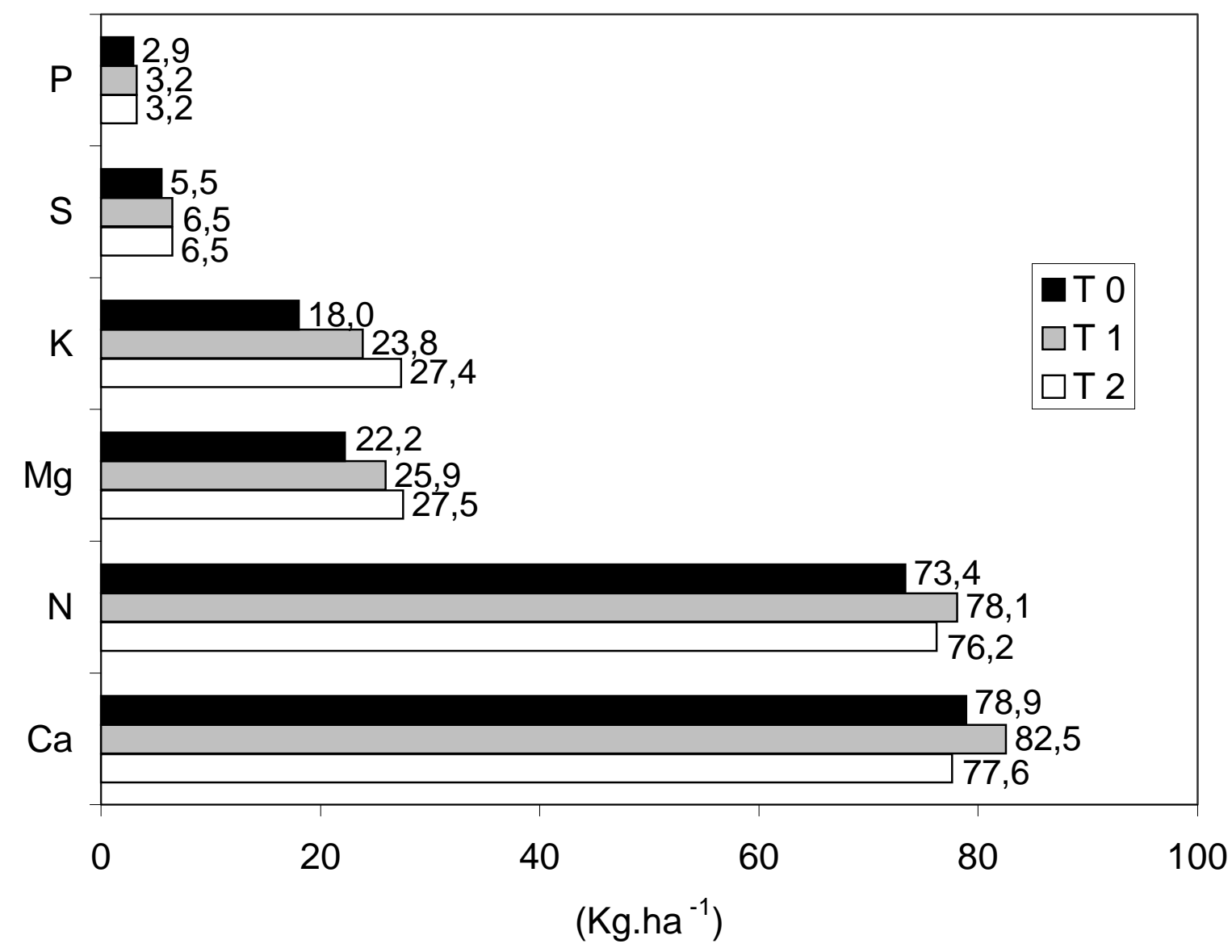

Figura 11. Deposição anual de macronutrientes ao solo. 
$\mathrm{Na}$ tabela 5, para efeito comparativo, foram compilados alguns valores anuais de deposição de serapilheira e nutrientes ao solo, deste e de outros trabalhos publicados.

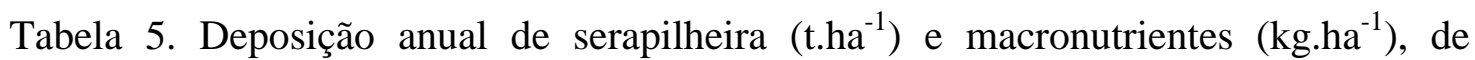
outubro de 1998 a setembro de 1999, nos três tratamentos, comparada com outras plantações de eucalipto.

\begin{tabular}{|c|c|c|c|c|c|c|c|c|}
\hline \multirow{2}{*}{ Trat. } & Serapilheira & $\mathrm{N}$ & $\mathrm{P}$ & K & $\mathrm{Ca}$ & $\mathrm{Mg}$ & $\mathrm{S}$ & \multirow[t]{2}{*}{ Ref. } \\
\hline & $\left(\mathrm{t} \cdot \mathrm{ha}^{-1}\right)$ & \multicolumn{6}{|c|}{$\mathrm{Kg} \mathrm{ha}^{-1}$} & \\
\hline T0 & 10,2 & 73,4 & 2,9 & 18,0 & 78,9 & 22,2 & 5,9 & (1) \\
\hline $\mathrm{T} 1$ & 10,9 & 78,1 & 3,2 & 23,8 & 82,5 & 25,9 & 7,1 & (1) \\
\hline $\mathrm{T} 2$ & 10,4 & 76,2 & 3,2 & 27,4 & 77,6 & 27,5 & 6,4 & (1) \\
\hline & 9,6 & 66,7 & 2,7 & 14,9 & 64,2 & 18,7 & - & (2) \\
\hline & 7,8 & 42,0 & 2,3 & 20,0 & 47,0 & - & - & (3) \\
\hline & 7,5 & 50,2 & 4,6 & 10,6 & 59,5 & 14,6 & - & (4) \\
\hline & 7,6 & 39,7 & 2,9 & 11,1 & 34,8 & 15,5 & - & $(5)$ \\
\hline & 4,0 & 66,4 & 4,1 & 26,7 & - & - & - & (6) \\
\hline & 8,5 & 58,0 & 4,2 & 40,0 & - & - & - & (7) \\
\hline & $3-11$ & $22-63$ & $2-4$ & $4-20$ & $18-160$ & $1-5$ & - & (8) \\
\hline
\end{tabular}

(1). Este trabalho. Espécie: Eucalyptus grandis aos 20 anos, manejados pelo sistema CCT.

(2). Turner \& Lambert (1983). Espécie: E. grandis aos 27 anos.

(3). Gonçalves et al. (1997). Espécie: E. grandis dos 7 aos 8 anos.

(4). Poggiani (1986). Espécie: E. saligna aos 11 anos.

(5). Carpanezzi (1980). Espécies: E. saligna x E. grandis dos 4 aos 5 anos.

(6). Bargali \& Singh (1991). Espécie: E. tereticornis aos 8 anos.

(7). George \& Varghese (1991) Espécie: E. globulus aos 10 anos.

(8). Negi et al. (1988). Espécies: E. acmenoides, E. eugenoides, E. paniculata, E. pilularis, E. propinqua de 74 a 75 anos. 


\subsection{Estoque de serapilheira acumulada sobre o solo}

Como se pode observar na tabela 6 , houve um maior acúmulo no período de verão, em todos os tratamentos estudados. Os valores de acúmulo de serapilheira do T0 foram semelhantes aos encontrados por Turner \& Lambert (1983), para E. grandis aos 27 anos de idade (17,4 t/ha), e por Fonseca et al. (1993), para de E. citriodora aos 25 anos de idade (18,5 t/ha).

Tabela 6. Estoque de serapilheira fina acumulada sobre o solo. Resultados de duas coletas (inverno e verão) e média para o ano de estudo, em t.ha ${ }^{-1}$.

\begin{tabular}{|l|c|c|c|}
\hline Tratamentos & Inverno (julho) & Verão (fevereiro) & Média Anual \\
\hline T0 & $15,6 \mathrm{a}$ & $20,6 \mathrm{a}$ & $18,1 \mathrm{a}$ \\
\hline T1 & $11,0 \mathrm{~b}$ & $15,9 \mathrm{~b}$ & $13,4 \mathrm{~b}$ \\
\hline T2 & $13,3 \mathrm{ab}$ & $16,4 \mathrm{ab}$ & $14,8 \mathrm{~b}$ \\
\hline
\end{tabular}

Médias seguidas de mesma letra não diferem entre si pelo teste de Tukey a 5\% de probabilidade.

Independente da época de coleta da serapilheira, o tratamento testemunha foi o que apresentou o maior acúmulo de serapilheira sobre o solo. Os tratamentos com desbaste foram semelhantes entre si. Estes resultados concordam com os de Vesterdal at al. (1995), que encontraram maior acúmulo de serapilheira e húmus no tratamento sem desbaste, em uma floresta de Picea abies de 47 - 51 anos de idade, na Dinamarca.

$\mathrm{O}$ menor estoque de serapilheira, nos tratamentos com desbaste, deve-se provavelmente às maiores taxas de decomposição da serapilheira, conforme será discutido no item 4.7.

Na Figura 12, estão apresentados os acúmulos médios de serapilheira para cada tratamento. 


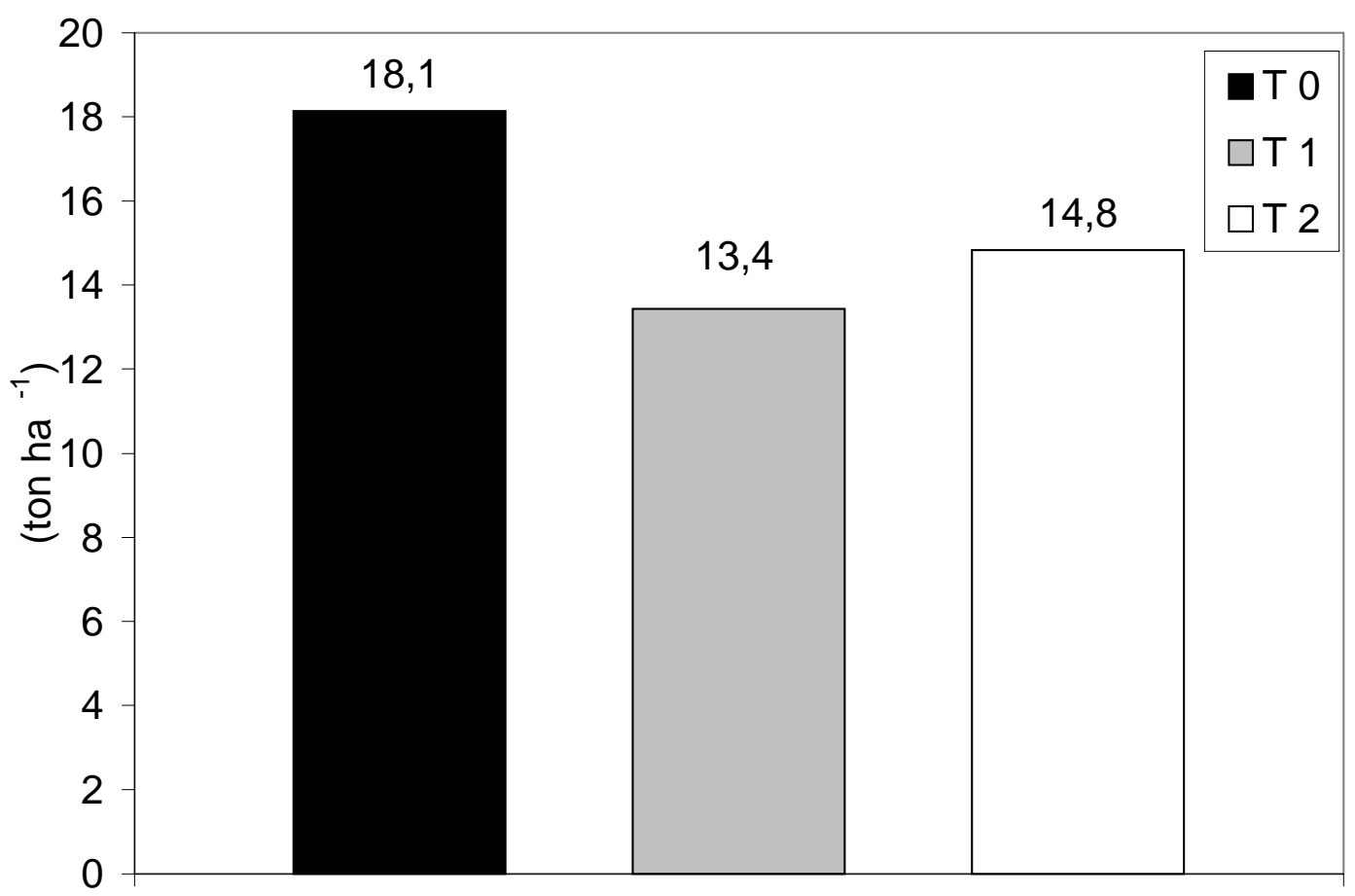

Figura 12. Estoque médio anual de serapilheira (t/ha) nos três tratamentos.

\subsection{Estoque de macronutrientes na serapilheira acumulada}

$\mathrm{Na}$ tabela 7, encontram-se os teores dos macronutrientes da serapilheira acumulada das amostras coletadas no verão e no inverno, bem como os teores médios anuais. Os teores praticamente não diferiram, entre as duas coletas. As exceções foram o cálcio (com maiores concentrações no verão) e o magnésio (com maiores concentrações no inverno). Observou-se uma tendência de haver maiores concentrações nos tratamentos com desbaste, principalmente no T1. Entretanto, considerando-se os valores médios anuais, houve diferença estatística entre os tratamentos apenas para o fósforo. 
Tabela 7. Concentração de macronutrientes na serapilheira acumulada.

\begin{tabular}{|c|c|c|c|c|}
\cline { 3 - 5 } \multicolumn{2}{c|}{} & \multicolumn{3}{c|}{ Concentração dos macronutrientes $\left(\mathrm{g} . \mathrm{Kg}^{-1}\right)$} \\
\hline Elementos & Tratamentos & Verão & Inverno & Média Anual \\
\hline \multirow{4}{*}{$\mathrm{N}$} & $\mathrm{T} 0$ & $6,4 \mathrm{c}$ & $6,9 \mathrm{a}$ & $6,7 \mathrm{a}$ \\
\cline { 2 - 5 } & $\mathrm{T} 1$ & $8,0 \mathrm{a}$ & $7,1 \mathrm{a}$ & $7,6 \mathrm{a}$ \\
\cline { 2 - 5 } & $\mathrm{T} 2$ & $7,1 \mathrm{~b}$ & $7,2 \mathrm{a}$ & $7,2 \mathrm{a}$ \\
\hline \multirow{4}{*}{$\mathrm{P}$} & $\mathrm{T} 0$ & $0,2 \mathrm{~b}$ & $0,3 \mathrm{a}$ & $0,3 \mathrm{~b}$ \\
\cline { 2 - 5 } & $\mathrm{T} 1$ & $0,4 \mathrm{a}$ & $0,4 \mathrm{a}$ & $0,4 \mathrm{a}$ \\
\cline { 2 - 5 } & $\mathrm{T} 2$ & $0,4 \mathrm{a}$ & $0,3 \mathrm{a}$ & $0,4 \mathrm{a}$ \\
\hline \multirow{4}{*}{$\mathrm{K}$} & $\mathrm{T} 0$ & $0,7 \mathrm{a}$ & $0,6 \mathrm{a}$ & $0,7 \mathrm{a}$ \\
\cline { 2 - 5 } & $\mathrm{T} 1$ & $0,7 \mathrm{a}$ & $0,6 \mathrm{a}$ & $0,7 \mathrm{a}$ \\
\cline { 2 - 5 } & $\mathrm{T} 2$ & $0,7 \mathrm{a}$ & $0,7 \mathrm{a}$ & $0,7 \mathrm{a}$ \\
\hline \multirow{3}{*}{$\mathrm{Ca}$} & $\mathrm{T} 0$ & $6,1 \mathrm{~b}$ & $4,9 \mathrm{a}$ & $5,5 \mathrm{a}$ \\
\cline { 2 - 5 } & $\mathrm{T} 1$ & $7,4 \mathrm{a}$ & $5,3 \mathrm{a}$ & $6,4 \mathrm{a}$ \\
\cline { 2 - 5 } & $\mathrm{T} 2$ & $6,1 \mathrm{~b}$ & $4,8 \mathrm{a}$ & $5,5 \mathrm{a}$ \\
\hline \multirow{3}{*}{$\mathrm{Mg}$} & $\mathrm{T} 0$ & $1,1 \mathrm{~b}$ & $2,4 \mathrm{~b}$ & $1,8 \mathrm{a}$ \\
\cline { 2 - 5 } & $\mathrm{T} 1$ & $1,5 \mathrm{a}$ & $2,9 \mathrm{a}$ & $2,2 \mathrm{a}$ \\
\cline { 2 - 5 } & $\mathrm{T} 2$ & $1,6 \mathrm{a}$ & $2,6 \mathrm{ab}$ & $2,1 \mathrm{a}$ \\
\hline \multirow{3}{*}{$\mathrm{S}$} & $\mathrm{T} 0$ & $0,5 \mathrm{a}$ & $0,5 \mathrm{a}$ & $0,5 \mathrm{a}$ \\
\cline { 2 - 5 } & $\mathrm{T} 1$ & $0,7 \mathrm{a}$ & $0,5 \mathrm{a}$ & $0,6 \mathrm{a}$ \\
\cline { 2 - 5 } & $\mathrm{T} 2$ & $0,6 \mathrm{a}$ & $0,4 \mathrm{a}$ & $0,5 \mathrm{a}$ \\
\hline
\end{tabular}

Médias seguidas de mesma letra não diferem entre si pelo teste de Tukey a 5\% de probabilidade.

$\mathrm{Na}$ tabela 8, encontram-se os estoques de macronutrientes na serapilheira acumulada das coletas de verão e inverno, bem com os estoques médios anuais. Os estoques de N, P, K, Ca e S na serapilheira acumulada foram maiores no verão. Esta diferença nos estoques de $\mathrm{P}$ e $\mathrm{S}$ foi ainda mais evidente nos tratamentos com desbaste. Apenas os estoques de Mg foram maiores no inverno.

Considerando-se os valores médios anuais, não houve diferença estatística no estoque de $\mathrm{P}$ e $\mathrm{Mg}$, entre os tratamentos. Os estoques dos demais nutrientes avaliados foram superiores na testemunha (T0), devido à sua maior biomassa de serapilheira sobre o solo e à decomposição mais lenta, que favorece a imobilização de nutrientes. Vesterdal et al (1995) também verificaram que o acúmulo de nutrientes decresceu com o aumento da intensidade de desbaste, em Picea abies de 47-51 anos de idade, na Dinamarca.

Os estoques de $\mathrm{Ca}$ e $\mathrm{Mg}$ estimados neste trabalho foram semelhantes aos encontrados por Turner \& Lambert (1983), para E. grandis, na Austrália. Delitti (1982) 
encontrou valores similares de estoque de $\mathrm{P}, \mathrm{K}$ e Ca na serapilheira de Pinus elliottii com 16 anos, mas os estoques de $\mathrm{N}$ e Mg foram superiores aos deste trabalho.

Tabela 8. Estoque de macronutrientes na serapilheira acumulada.

\begin{tabular}{|c|c|c|c|c|}
\cline { 3 - 5 } \multicolumn{1}{c|}{} & \multicolumn{3}{c|}{ Mineralomassa na serapilheira acumulada $\left(\mathrm{Kg}^{\mathrm{c}} \mathrm{ha}^{-1}\right)$} \\
\hline Nutrientes & Tratamentos & Verão & Inverno & Média Anual \\
\hline \multirow{3}{*}{$\mathrm{N}$} & $\mathrm{T} 0$ & $134,34 \mathrm{a}$ & $108,02 \mathrm{a}$ & $121,49 \mathrm{a}$ \\
\cline { 2 - 5 } & $\mathrm{T} 1$ & $127,12 \mathrm{a}$ & $76,99 \mathrm{~b}$ & $102,06 \mathrm{~b}$ \\
\cline { 2 - 5 } & $\mathrm{T} 2$ & $117,87 \mathrm{a}$ & $96,39 \mathrm{ab}$ & $106,80 \mathrm{~b}$ \\
\hline \multirow{3}{*}{$\mathrm{P}$} & $\mathrm{T} 0$ & $5,07 \mathrm{a}$ & $5,45 \mathrm{a}$ & $5,44 \mathrm{a}$ \\
\cline { 2 - 5 } & $\mathrm{T} 1$ & $5,85 \mathrm{a}$ & $3,95 \mathrm{a}$ & $5,37 \mathrm{a}$ \\
\cline { 2 - 5 } & $\mathrm{T} 2$ & $6,34 \mathrm{a}$ & $4,78 \mathrm{a}$ & $5,93 \mathrm{a}$ \\
\hline \multirow{3}{*}{$\mathrm{K}$} & $\mathrm{T} 0$ & $14,12 \mathrm{a}$ & $9,39 \mathrm{a}$ & $12,69 \mathrm{a}$ \\
\cline { 2 - 5 } & $\mathrm{T} 1$ & $11,59 \mathrm{a}$ & $6,93 \mathrm{a}$ & $9,40 \mathrm{~b}$ \\
\cline { 2 - 5 } & $\mathrm{T} 2$ & $11,22 \mathrm{a}$ & $9,60 \mathrm{a}$ & $10,38 \mathrm{ab}$ \\
\hline \multirow{3}{*}{$\mathrm{Ca}$} & $\mathrm{T} 0$ & $125,93 \mathrm{a}$ & $76,03 \mathrm{a}$ & $99,73 \mathrm{a}$ \\
\cline { 2 - 5 } & $\mathrm{T} 1$ & $117,32 \mathrm{a}$ & $57,87 \mathrm{a}$ & $85,95 \mathrm{~b}$ \\
\cline { 2 - 5 } & $\mathrm{T} 2$ & $101,08 \mathrm{a}$ & $64,23 \mathrm{a}$ & $81,58 \mathrm{~b}$ \\
\hline \multirow{3}{*}{$\mathrm{Mg}$} & $\mathrm{T} 0$ & $23,34 \mathrm{a}$ & $36,95 \mathrm{a}$ & $32,64 \mathrm{a}$ \\
\cline { 2 - 5 } & $\mathrm{T} 1$ & $24,16 \mathrm{a}$ & $31,29 \mathrm{a}$ & $29,54 \mathrm{a}$ \\
\cline { 2 - 5 } & $\mathrm{T} 2$ & $25,58 \mathrm{a}$ & $33,68 \mathrm{a}$ & $31,15 \mathrm{a}$ \\
\hline \multirow{3}{*}{$\mathrm{S}$} & $\mathrm{T} 0$ & $10,48 \mathrm{a}$ & $8,44 \mathrm{a}$ & $9,07 \mathrm{a}$ \\
\cline { 2 - 5 } & $\mathrm{T} 1$ & $11,06 \mathrm{a}$ & $5,06 \mathrm{~b}$ & $8,06 \mathrm{ab}$ \\
\cline { 2 - 5 } & $\mathrm{T} 2$ & $9,93 \mathrm{a}$ & $5,92 \mathrm{ab}$ & $7,42 \mathrm{~b}$ \\
\hline
\end{tabular}

Médias seguidas de mesma letra não diferem entre si pelo teste de Tukey a 5\% de probabilidade.

\subsection{Decomposição da serapilheira acumulada sobre o solo}

O tratamento sem desbaste teve a menor produção anual de serapilheira (10,2 t/ha/ano); porém apresentou maior acúmulo de serapilheira sobre o solo $(18,1 \mathrm{t} / \mathrm{ha})$. $\mathrm{O}$ T1, por sua vez, teve a maior deposição de serapilheira (10,9 t/ha/ano) e o menor acúmulo sobre o solo (13,4 t/ha). Já o T2 apresentou os valores intermediários tanto de deposição (10,4 t/ha/ano) quanto de acúmulo (14,83 t/ha). Estas diferenças entre produção e acúmulo de serapilheira estão relacionadas com as diferentes taxas de decomposição dos componentes.

De acordo com Vesterdal et al. (1995), os desbastes modificam o microclima, reduzindo a evapotranspiração e aumentando a radiação solar que atinge o solo, o que 
favorece os microorganismos decompositores. Eles sugerem também que a redução na competição entre as árvores remanescentes aumenta a disponibilidade de nutrientes por árvore e possibilita um maior desenvolvimento do sub-bosque. Estes dois fatores resultariam numa serapilheira mais rica em nutrientes e mais facilmente decomponível.

Os povoamentos com desbaste (principalmente o T1) tiveram as maiores taxas de decomposição e, consequentemente, necessitam de menos tempo para a renovação da serapilheira acumulada.

Os valores de $\mathrm{K}$, o tempo médio de renovação da serapilheira acumulada (1/K) e os tempos necessários para a decomposição de $50 \%$ e $95 \%$ da serapilheira, para os três tratamentos, estão apresentados na Tabela 9. De acordo com Pagano (1989), altos valores para a constante $\mathrm{K}$ sugerem um rápido reaproveitamento de nutrientes por parte da vegetação.

Tabela 9. Taxas de decomposição $(\mathrm{K})$, tempo médio de renovação da serapilheira $(1 / \mathrm{K})$ e tempos necessários para a decomposição de $50 \%$ (t 0,5) e 95\% (t 0,05) da serapilheira (anos).

\begin{tabular}{|c|c|c|c|c|}
\hline Tratamento & $\mathrm{K}$ (anos) & $1 / \mathrm{K}$ (anos) & $\mathrm{t} 0,5$ (anos) & $\mathrm{t} 0,05$ (anos) \\
\hline T0 & 0,56 & 1,77 & 1,24 & 5,36 \\
\hline T1 & 0,81 & 1,24 & 0,86 & 3,70 \\
\hline T2 & 0,70 & 1,43 & 0,99 & 4,29 \\
\hline
\end{tabular}

O tempo médio de renovação da serapilheira foi superior a 1 ano para todos os tratamentos, e foi de quase 2 anos para a testemunha. $\mathrm{O}$ valor encontrado para o T1 foi muito semelhante ao encontrado por Turner \& Lambert (1983), para a mesma espécie, $\operatorname{aos} 27 \operatorname{anos}(t=1,25$ anos $)$.

Poggiani (1985) encontrou, para E. saligna aos 7 anos, tempo de renovação do folhedo $\mathrm{K}=1,78$ anos; e tempos de decomposição de $50 \%$ e $95 \%$ do folhedo de 1,2 e 5,3 anos, respectivamente. Os valores foram muito semelhantes aos encontrados neste trabalho (Tabela 9).

Para decompor 50\% da serapilheira, são necessários 453 dias no T0, 314 dias no T1 e 361 dias no T2. 


\subsection{Mineralomassa do solo}

Na tabela 10 são apresentados os estoques dos macronutrientes contidos na camada de solo entre 0 a $20 \mathrm{~cm}$ de profundidade. Com exceção do N- total, os demais nutrientes representam o reservatório imediatamente disponível.

Tabela 10. Mineralomassa do solo $\left(\mathrm{Kg} \mathrm{ha}^{-1}\right)$ na camada entre $0-20 \mathrm{~cm}$ de profundidade. ( $\mathrm{N}$ - total; $\mathrm{P}$ disponível; K, Ca e Mg trocáveis).

\begin{tabular}{|l|c|c|c|c|c|}
\hline \multirow{2}{*}{ Tratamentos } & $\mathrm{N}$ & $\mathrm{P}$ & $\mathrm{K}$ & $\mathrm{Ca}$ & $\mathrm{Mg}$ \\
\cline { 2 - 6 } & \multicolumn{5}{|c|}{ Kg ha $^{-\mathbf{1}}$} \\
\hline T0 & $150,0 \mathbf{a}$ & $14,1 \mathbf{a}$ & $19,6 \mathbf{b}$ & $118,9 \mathbf{b}$ & $40,1 \mathbf{b}$ \\
\hline T1 & $142,0 \mathbf{a b}$ & $16,3 \mathbf{a}$ & $31,1 \mathbf{a}$ & $252,9 \mathbf{a}$ & $77,1 \mathbf{a}$ \\
\hline T2 & $119,3 \mathbf{b}$ & $14,4 \mathbf{a}$ & $27,8 \mathbf{a b}$ & $210,0 \mathbf{a}$ & $51,4 \mathbf{b}$ \\
\hline
\end{tabular}

Médias seguidas de mesma letra não diferem entre si pelo teste de Tukey a 5\% de probabilidade.

O solo das áreas estudadas é extremamente pobre, o que demonstra uma grande dependência da entrada de nutrientes no ecossistema através da aduabação ou deposição atmosférica e também da sua capacidade de conservá-los no sítio através dos ciclos bioquímico e biogeoquímico. Neste sentido, Attiwill (1980), ao estudar florestas de eucaliptos na Austrália, em sítios de fertilidade muito baixa, observou que a demanda de nutrientes aumenta ligeiramente com a idade das árvores, mas que uma proporção cada vez mais expressiva desta demanda é suprida pelo próprio ciclo biológico, que se torna proporcionalmente mais importante à medida em que a floresta atinge a maturidade.

Gonçalves et al. (2000) salientam que, em povoamentos adultos de Eucalyptus. grandis, após o fechamento das copas, grande parte da demanda de nutrientes é atendida através da reciclagem. Isto significa uma dependência, cada vez menor, das árvores em relação ao estoque de nutrientes contidos no solo. Os nutrientes, uma vez armazenados na biomassa das árvores, durante a fase juvenil, são disponibilizados, ao longo do tempo, através do ciclo bioquímico.

Observa-se na tabela 10, que os estoques de macronutrientes no solos seguem, de um modo geral, a sequiência $\mathrm{Ca}>\mathrm{N}>\mathrm{Mg}>\mathrm{K}>\mathrm{P}$ e, apenas no T0 (testemunha), o 
estoque de $\mathrm{N}$ é superior ao de Ca. Observa-se, também, que os estoques de nutrientes no solo do T1, são superiores aos existentes nos demais tratamentos, exceto em relação ao nitrogênio, e os valores mais baixos são observados no T0.

Deve-se assinalar que, para esta pesquisa, as coletas de solo para a análise foram realizadas no período de inverno, época em que a atividade de decomposição e de mineralização é mais lenta, o que poderia estar reduzindo a disponibilidade de nutrientes neste período do ano. Carlyle (1995), na Austrália, estudando um povoamento de Pinus radiata, com 10 anos de idade, ao longo de 3 anos após o desbaste, verificou que o desbaste provocou um aumento de $10 \%$ nas taxas de mineralização e absorção de $\mathrm{N}$, além de um pequeno aumento na concentração deste elemento no solo, entre 0 a $30 \mathrm{~cm}$ de profundidade.

Também Vieira (1998), estudando comparativamente a ciclagem de nutrientes em diferentes ecossistemas da Estação Experimental de Itatinga (SP), localizados sobre um Latossolo Vermelho Amarelo de baixa fertilidade, encontrou estoques muito baixos de N-total, nos primeiros $60 \mathrm{~cm}$ de profundidade, sendo: $265 \mathrm{Kg} / \mathrm{ha}$ sob vegetação natural de cerrado; 197,5 Kg/ha sob um talhão de E. grandis, com 6 anos de idade e apenas $24,5 \mathrm{Kg} / \mathrm{ha}$, sob um talhão maduro de E. saligna, explorado por sucessivos cortes durante 50 anos e sem qualquer aplicação de adubo.

Observa-se ainda, na tabela 10, que o Ca foi o elemento que apresentou maiores estoques nos tratamentos desbastados (T1 e T2). Os valores são semelhantes aos encontrados por Vieira (1998) e por Fonseca et al. (1993). Estes últimos autores, salientam que, os elementos Ca e $\mathrm{K}$ podem tornar-se tão críticos quanto o fósforo, na manutenção da produção sustentada em florestas de rápido crescimento.

Deve ser considerado também, que os componentes das árvores desbastadas, tais como: folhas, ramos, cascas e raízes, permanecendo no sítio após a colheita florestal, devem ter proporcionado uma significativa contribuição para o solo devido à sua decomposição e conseqüente mineralização dos nutrientes contidos na biomassa. 


\subsection{Implicações silviculturais do balanço nutricional}

Um aspecto importante da ciclagem de nutrientes está relacionado com a quantidade de nutrientes estocados na serapilheira, principalmente nas regiões onde o solo é de fertilidade muito baixa e nas épocas em que a decomposição e mineralização se tornam mais lentas (Poggiani, 1985). A tabela 11 apresenta, para cada tratamento e para cada nutriente, a relação entre o conteúdo disponível no solo e na serapilheira acumulada. Um valor baixo da relação (solo/serapilheira), significa uma maior retenção de nutrientes na serapilheira, tornando os nutrientes menos disponíveis para o sistema radicular dos eucaliptos.

Tabela 11. Relação entre os conteúdos de nutrientes no solo, entre 0 e $20 \mathrm{~cm}$ de profundidade, e os estocados na serapilheira acumulada. - Estoques de nutrientes contidos no solo $\left(\mathrm{Kg} \mathrm{ha}^{-1}\right) /$ estoques de nutrientes contidos na serapilheira $\left(\mathrm{Kg} \mathrm{ha}^{-1}\right)$.)

\begin{tabular}{|l|c|c|c|c|c|}
\hline \multirow{2}{*}{ Tratamentos } & \multicolumn{5}{|c|}{ Elementos } \\
\cline { 2 - 6 } & $\mathrm{N}$ & $\mathrm{P}$ & $\mathrm{K}$ & $\mathrm{Ca}$ & $\mathrm{Mg}$ \\
\hline T0 (0\%) & 1,23 & 2,59 & 1,54 & 1,19 & 1,23 \\
\hline T1 (67\%) & 1,39 & 3,04 & 3,31 & 2,94 & 2,61 \\
\hline T2 $(83 \%)$ & 1,12 & 2,43 & 2,68 & 2,57 & 1,65 \\
\hline
\end{tabular}

Verifica-se que o T1 apresenta os maiores valores, para todos os nutrientes e o $\mathrm{T} 0$ apresenta os valores mais baixos para o elementos $\mathrm{K}, \mathrm{Ca}$ e $\mathrm{Mg}$.

Esta pesquisa evidencia, também, que o T0 apresenta a menor taxa de decomposição e o maior estoque de nutrientes na serapilheira acumulada. Isto significa que, devido à lenta decomposição no T0, está ocorrendo uma imobilização dos nutrientes (especialmente de $\mathrm{K}, \mathrm{Ca}$ e $\mathrm{Mg}$ ) na serapilheira e, consequentemente, um menor estoque de nutrientes no solo (exceto para o N). Por outro lado, o T1 apresenta maior transferência de nutrientes, via produção de serapilheira, e menor acúmulo destes na serapilheira. Neste tratamento, a maior velocidade de decomposição da serapilheira disponibiliza rapidamente os nutrientes para a camada superficial do solo. Desta forma, o solo do T1 apresenta um maior estoque de nutrientes (exceto para o $\mathrm{N}$ ). 
Para efeito de comparação, na tabela 12, os estoques de nutrientes do solo foram somados aos da serapilheira. Verifica-se também que os povoamentos desbastados possuem os maiores estoques de $\mathrm{P}, \mathrm{K}, \mathrm{Ca}$ e $\mathrm{Mg}$, considerando o sistema (solo + serapilheira), o que contribui para a melhoria da qualidade do sítio.

Tabela 12. Estoques de nutrientes no sistema (solo - 0 a $20 \mathrm{~cm}+$ serapilheira acumulada).

\begin{tabular}{|l|c|c|c|c|c|}
\hline \multirow{2}{*}{ Tratamentos } & $\mathrm{N}$ & $\mathrm{P}$ & $\mathrm{K}$ & $\mathrm{Ca}$ & $\mathrm{Mg}$ \\
\cline { 2 - 6 } & \multicolumn{5}{|c|}{$\mathrm{Kg} \mathrm{ha}^{-1}$} \\
\hline T0 & 271,5 & 19,5 & 32,3 & 218,6 & 72,7 \\
\hline T1 & 244,1 & 21,7 & 40,5 & 338,9 & 106,6 \\
\hline T2 & 226,1 & 20,3 & 38,2 & 291,6 & 82,6 \\
\hline
\end{tabular}

Após este resultados, surge uma pergunta. Qual seria, ao longo do tempo, o impacto dos desbastes no balanço nutricional dos povoamentos de eucaliptos? Neste sentido, dados estimados pela empresa que explorou a madeira, indicam ter havido uma retirada de até 111 t/ha de (madeira + casca) devido aos desbastes. A exportação de nutrientes no T2 teria sido, portanto, em torno de $117 \mathrm{Kg}$ de $\mathrm{N} ; 3 \mathrm{Kg}$ de P; $140 \mathrm{Kg}$ de $\mathrm{K} ; 267 \mathrm{Kg}$ de $\mathrm{Ca}$ e $17 \mathrm{Kg}$ de $\mathrm{Mg}$ por hectare. Estes valores são semelhantes aos estimados por Silva (1983), num povoamento de Eucalyptus grandis, aos 10 anos de idade, plantado em solo arenoso e de baixa fertilidade, na região de Itirapina - SP. Consequentemente, se quantidades relativamente elevadas de nutrientes foram exportadas devido aos desbastes, como poderiam ser explicados os maiores estoque de nutrientes no solo e no sistema (solo + serapilheira) dos tratamentos desbastados T1 e $\mathrm{T} 2$ deste experimento ?

Neste sentido, Poggiani \& Schumacher (1997), discutindo o balanço nutricional em plantações florestais, reuniram alguns dados da região central do Estado de São Paulo, referentes às entradas anuais de nutrientes via precipitação atmosférica. Supondo-se a manutenção dos valores mencionados por estes autores ao longo do tempo, pode-se inferir que no período de 13 anos - decorridos entre o final dos desbastes (aos 7 anos) e a idade de avaliação (aos 20 anos)-, a entrada total de nutrientes poderia ter sido, por hectare, de até $95 \mathrm{Kg}$ de N; $12 \mathrm{Kg}$ de P; $127 \mathrm{Kg}$ de K; 
$208 \mathrm{Kg}$ de $\mathrm{Ca}$ e $68 \mathrm{Kg}$ de $\mathrm{Mg}$. Estas entradas de nutrientes, portanto, poderiam ser suficientes para minimizar, ou mesmo compensar, as perdas devido à colheita da madeira. Isto sugere que, em rotações longas, a entrada anual de nutrientes via atmosfera (inclusive a fixação do N), embora pareça pequena, pode permitir que ocorra até o final do ciclo, uma contribuição considerável para ar o assegurar o equilíbrio nutricional do ecossistema.

Turner e Lambert (1983), na Austrália, também comprovaram a importância do uso de rotações mais longas na manutenção da capacidade produtiva de plantações florestais de Ecalyptus grandis. A partir de suas observações, sugeriram que a exploração dos eucaliptos deveria ser evitada antes da floresta atingir 15 anos de idade, com a finalidade de se propiciar um maior equilíbrio no balanço nutricional.

Neste experimento, devido aos desbastes sucessivos, cada árvore remanescente passou a dispor de um maior volume de solo para expandir seu sistema radicular o que dever ter inclusive possibilitado uma acentuada retomada na reabsorção dos nutrientes, além da consequentemente redução nas perdas por lixiviação, geralmente muito elevada em solos arenosos.

Segundo a hipótese de Vitousek \& Reiners (1975), nesta fase da sucessão (após desbaste), em que há uma retomada no incremento da biomassa aérea e das raízes do talhão florestal, haveria também um aumento na taxa de absorção dos nutrientes vindos da deposição atmosférica e da decomposição e mineralização dos restos da colheita. Isto acarretaria uma elevada capacidade de retenção dos nutrientes no ecossistema, conforme se observa nos resultados deste experimento. 


\section{CONCLUSÕES}

1) A transferência de nutrientes através da deposição de serapilheira, nos povoamentos desbastados, foi maior do que na testemunha. Todavia, as diferenças não foram estatisticamente significativas.

2) Em todos os tratamentos a deposição de serapilheira foi maior no período quente e chuvoso de novembro a março.

3) Nos tratamentos com desbaste, a quantidade de serapilheira acumulada sobre o solo, bem como os estoques de nutrientes nela contidos foram inferiores em relação à testemunha.

4) Nos tratamentos com desbaste (especialmente no T1) foi observada uma maior taxa de decomposição da serapilheira. A menor taxa de decomposição da serapilheira, observada no tratamento sem desbaste, pode estar associada a fatores microclimáticos desfavoráveis aos processos de decomposição.

5) Efetivamente, em todas as profundidades estudadas, o teores de umidade do solo, no tratamento testemunha, foram cerca de duas vezes superiores aos dos tratamentos desbastados, indicando um maior processo de evapotranspiração nestes últimos. Consequentemente, pode-se inferir que o maior teor de umidade, associado à menor luminosidade e à temperatura ligeiramente inferior, tornaram a decomposição mais lenta no tratamento testemunha.

6) Sendo mais lenta a decomposição, o povoamento testemunha imobilizou uma maior quantidade de elementos na serapilheira (especialmente $\mathrm{K}, \mathrm{Ca}$ e $\mathrm{Mg}$ ). 
7) Entre 0 e $20 \mathrm{~cm}$ de profundidade, os solos dos tratamentos com desbaste (especialmente o T1) apresentaram maiores estoques de nutrientes em relação ao T0 (exceto para o $\mathrm{N}$ ), devido à disponibilização dos nutrientes liberados pela mais rápida decomposição da serapilheira.

8) Os resultados deste estudo mostram que a aplicação de desbastes progressivos em povoamentos de eucaliptos, quando manejados em regimes de ciclos mais longos do que usualmente vem sendo aplicados atualmente (5 - 6 anos), podem favorecer a reciclagem dos nutrientes que entram no ecossistema, conservando mais eficientemente seus estoques no sistema (solo + serapilheira) e contribuído para manter a produtividade do sítio. 


\section{REFERÊNCIAS BIBLIOGRÁFICAS}

ACIESP. Glossário de Ecologia. 2. Ed. São Paulo: ACIESP - Academia de Ciências do Estado de São Paulo, 1997. 352p.

ANDRAE, F.H. Ecologia Florestal. Santa Maria: Universidade Federal de Santa Maria, 1978. 230p.

ASHTON, P.M.S. Some measurements of the microclimate within a Sri Lankan tropical rain forest. Agricultural and Forest meteorology, v.59, n. 3/4, p. 217-235, jul. 1992.

ATTIWILL, P.M. The loss of elements from decomposing litter. Ecology, v.49, n.1, p.142-145, 1968.

BAHUGUNA, V.K.; NEGI, J.D.S; JOSHI, S.R.; NAITHANI, K.C. Leaf litter decomposition and nutrient release in Shorea robusta and Eucalyptus camaldulensis plantation. Indian Forester, v. 116, n. 2, p. 103-114, feb.1990.

BAKER, F.S. Principles of Silviculture. New York: McGraw Hill, 1950. 414p.

BARGALI, S.S.; SINGH, S.P. Aspects of productivity and nutrient cycling in na 8-year old Eucalyptus plantation in a moist plain area adjacent to central Himalaya, India. Canadian Journal of Forest Research, v. 21, p. 1365-1372, 1991.

BARROS, N.F.; NOVAIS, R.F. Relação Solo-Eucalipto. Viçosa: Ed. Folha de Viçosa, 1990. 330p. 
BARROS, N.F.; NOVAIS, R.F.; NEVES, J.C.L. Fertilização e correção do solo para o plantio de eucalipto. In: BARROS, N.F.; NOVAIS, R.F. (Ed.) Relação SoloEucalipto. Viçosa: Ed. Folha de Viçosa, 1990, p.127-186.

BELlOTE, A.F.J.; SARRUGE, J.R.; HAAG, H.P.; OLIVEIRA, G.D. Extração e exportação de nutrientes pelo Eucalyptus grandis Hill ex-Maiden em função da idade: 1. Macronutrientes. IPEF, v. 20, p. 1-23, 1980.

BOCKHEIM, J.G.; JEPSEN, E.A.; HEISEY, D.M. Nutrient dynamics in decomposing leaf litter of four tree species on a sandy soil in northwestern Wisconsin. Canadian Journal Forest Research, v. 21, n. 6, p. 803-12, jun. 1991.

BRAY, J.R.; GORHAM, E. Litter production in forests of the world. Advances in Ecological Research, v.2, p.101-57, 1964.

CARPANEZZI, A.A. Deposição de material orgânico e nutrientes em uma floresta natural e em uma plantação de eucaliptos no interior do estado de São Paulo. São Paulo, 1980. 115p. Dissertação (Mestrado). Escola Superior de Agricultura Luiz de Queiroz, Universidade de São Paulo.

CÉSAR, O. Produção de serapilheira na mata mesófila semidecídua da Fazenda Barreiro Rico, município de Anhembi, SP. Revista Brasileira de Biologia, v. 53, n. 4, p. 671-681, 1993.

COLE, D.W.; RAPP, M. Elemental cycling in florested ecosystems. In: REICHLE, D.E. (Ed.) Dynamic properties of forest ecosystems. Cambridge, England: Cambridge University Press, 1980, p. 341-409.

COSTA, L.M. Manejo de solos em áreas reflorestadas. In: BARROS, N.F.; NOVAIS, R.F. (Ed.) Relação Solo-Eucalipto. Viçosa: Ed. Folha de Viçosa, 1990, p. 237-264.

CUNHA, G.C.; GRENDENE, L.A.; DURLO, M.A.; BRESSAN, D.A. Dinâmica sucessional em Floresta Estacional Decidual com ênfase aos minerais provenientes da deposição da serapilheira. Ciência Florestal, v.3, n.1, p.35-64, 1993. 
CURLIN, J.W. Nutrient cycling as a factor in site productivity and forest fertilization. In: YOUNBERG, C.T.; DAVEY, C.B. (Eds.) Tree growth and forest soils. Oregon State University Press, 1970. p. 313-325.

CUSTÓDIO FILHO, A. Produção e decomposição de serapilheira em um trecho da floresta pluvial atlântica - Estação Biológica de Boracéia (São Paulo - Brasil). São Paulo, 1994, 72p. Dissertação (MESTRADO). Escola Superior de Agricultura Luiz de Queiroz, Universidade de São Paulo.

DAJOZ, R. Ecologia Geral. 3 ed. Petrópolis, Vozes, 1978, 472 p.

DELITTI, W.B.C. Aspectos dinâmicos da serapilheira de uma floresta implantada de Pinus elliottii Engelm. var. elliottii (Mogi-Guaçu, SP). São Paulo, 1982. 137 p. Dissertação (Mestrado) Instituto de Biociências, Universidade de São Paulo.

DIVIGNEAUD, P.; DENAEYER DE SMET, S. Biological cycling of minerals in temperate deciduous forests. In: REICHLE, D.E.D. (Ed.) Analyses of temperate Forest Ecosystem. New York: Springer-Verlag, 1973. p. 199-225.

FELLER, M.C. Effects of an exotic conifer (Pinus radiata) plantation on forest nutrient cycling in southeastern Australia. Forest Ecology and Management v.7, n.2, p.77$102,1983$.

FERREIRA, C.A. Nutritional Aspects of the Management of Eucalyptus Plantations on Poor Sandy Soils of the Brasilian Cerrado Region. Tese (Doutorado). Oxford University, 1989.

FONSECA, S; BARROS, N.F.; NOVAIS, R.F.; COSTA, L.M.; LEAL, P.G.L.; NEVES, J.C.L. Alterações em um latossolo sob eucalipto, mata natural e pastagem: Ipropriedades físicas e químicas. Revista Árvore, v.17, n.3, p.271-288, set./dez.1993. 
GABRIEL, J.L.C. Florística, fitossociologia de espécies lenhosas e aspectos da ciclagem de nutrientes em floresta mesófila semidecídua nos municípios de Anhembi e Bofete, SP. Rio Claro,1997. 195p. Tese (Doutorado). Instituto de Biociências. Universidade Estadual Paulista.

GEORGE, M.; VARGHESE, G. Nutrient cycling in Eucalyptus globulus plantation. IIINutrients retained, returned uptake and nutrients cycling. Indian Forester, v. 117, n. 2, p. 110-116, feb. 1991.

GONÇALVES, J.L.M. Características do sistema radicular de absorção do Eucalyptus grandis sob diferentes condições edáficas. Piracicaba, 1994. 84p. Tese (Livre Docência). Escola Superior de Agricultura "Luiz de Queiroz", Universidade de São Paulo.

GONÇALVES, J.L.M.; STAPE, J.L.; BENEDETTI, V.; FESSEL, V.A.G.; GAVA, J.L. Reflexos do cultivo mínimo e intensivo do solo em sua fertilidade e na nutrição das árvores. In: GONÇALVES, J.L.M.; BENEDETTI, V. (Eds.) Nutrição e Fertilização Florestal. Piracicaba: IPEF, 2000, cap. 1, p. 1-57.

GONÇALVES, J.L.M.; POGGIANI, F.; STAPE, J.L.; SERRANO, M.I.P.; MELLO, S.L.M.; MENDES, K.C.F.S.; JORGE, L.A.C. Efeito de práticas de cultivo mínimo e intensivo do solo sobre a ciclagem de nutrientes, fertilidade do solo, configuração do sistema radicular e nutrição mineral de povoamentos de Eucalyptus grandis. Piracicaba, 1997. 94p. (Relatório Final de Pesquisa, FAPESP, processo $\left.n^{0} 1994 / 4248-4\right)$.

GONZALEZ, M.I.M.; GALLARDO, J.F. El efecto hojarasca: una reision. Anales de Edafologia y Agrobiologia. v. 41, p. 1129-1157, 1982.

HAAG, H.P.; ROCHA FILHO, J.V.C; OLIVEIRA, G.D. Ciclagem de nutrientes em florestas implantadas de Eucalyptus e Pinus. II. Contribuição das espécies nos nutrientes na manta orgânica. O Solo, v. 70, n. 2, p.28-31, 1978. 
HANSEN, E.A.; BAKER, J.B. Biomass and nutrient removal in short rotation intensively cultured plantations. In: ANNUAL MEETING NORTH AMERICAN POPLARS CONCIL, Thompsonville, 1979. Anais. Thompsonville, 1979. p. 130151.

HARMON, M.E.; BAKER, G.A.; SPYCHER, G.; GREENE, S.E. Leaf-litter decomposition in the Picea/Tsuga forests of the Olympic National Park, Washington, U.S.A. Forest Ecology and Management, v. 31, (1990). p.55-66.

HART, S.C.; FIRESTONE, M.K.; PAUL, E.A. Decomposition and nutrient dynamics of ponderosa pine needles in a Mediterranean-type climate. Canadian Journal Forest Research, v. 22, p. 306-314, 1992.

HILEY, W.E. Conifers: South African methods of cultivation. London: Faber and Faber, 1959. cap. 7, p.83-123.

JACOBS, M. The tropical rain forest - a first encounter. Berlin: Spriner-Verlag, 1988. 295 p.

KENNEY, D.R. Prediction of soil nitrogen availability in forest ecosystems: 2 literature review. Forest Science, v. 26, n.1, p. 159-171, 1980.

KIMMINS, J.P. Sustained yield, timber mining, and the ecological rotations: a British Columbia view. Forestry Cronicle, v. 50, p. 1-4, 1974.

LAMPRECHT, H. Silvicultura nos Trópicos: ecossistemas florestais e respectivas espécies arbóreas- possibilidades e métodos de aproveitamento sustentado. Eschborn: GTZ GmbH - Rosdorf: TZ - Verl. - Ges., 1990. 344p.

LIMA, W.P. Impacto ambiental do eucalipto. 2. ed. São Paulo: EDUSP, 1996. 302p.

LISANEWORK, N.; MICHELSEN, A. Litterfall and nutrient release by decomposition in three plantations compared with a natural forest in the Ethiopian highland. Forest Ecology and Management, v.65 (1994), p.149-164, 1994. 
LOPES, A.S. Solos sob cerrado - características, propriedades e manejo. Piracicaba: POTAFOS, 1983. 162p.

LOUSIER, J.D.; PARKINSON, D. Litter decomposition in a cool temperate deciduous forest. Cannadian Journal of Botanic, v. 54, p. 419-436, 1976.

LUBRANO, L. Ricerche sulle esigenze nutritive di alcune speci eucalitti. Publicazion: Centro di Sperimentazione Agricola e Forestale, v. 11, p. 1-15, 1972.

LUZ, H.F.; MELZER, J.F.; COUTINHO, C.J.; FERREIRA, M.C. Manejo de Florestas de Eucalipto para Usos Múltiplos. In: CONGRESSO FLORESTAL BRASILEIRO, 7 /CONGRESSO FLORESTAL PANAMERICANO, 1, Curitiba, 1993. Anais. Curitiba: SBS/SBEF, 1993, v. 3, p. 283-290.

NEGI, J.D.S.; SHARMA, S.C.; BISHT, A.P.S. Forest floor and soil nutrient inventories in na old growth Ecaliyptus plantations. Indian Forester, v. 114, n. 8, p. 453-461, ago. 1988.

NEVES, J.C.L.; BARROS, N.F.; NOVAIS, R.F.; ANJOS, J.L. Efeito do Alumínio em amostras de dois latossolos sob cerrado sobre o crescimento e a absorção de nutrientes de mudas de Eucalyptus spp. ACIESP. Glossário de Ecologia. 2. ed. São Paulo: Publicação ACIESP - Academia de Ciências do Estado de São Paulo, 1997. 352p.

NOVAIS, R.F.; BARROS, N.F.; NEVES, J.C.L. Interpretação da análise química do solo para o crescimento de Eucaliptus spp - níveis críticos de implantação e manutenção. Revista Árvore, v.10, n. 1, p. 105-111, jan./jun. 1986.

NOVAIS, R.F; BARROS, N.F.; NEVES, J.C.L. Nutrição mineral do Eucalipto. In: BARROS, N.F.; NOVAIS, R.F. Relação Solo-Eucalipto. Viçosa, Ed. Folha de Viçosa, 1990. p. 25-98.

OLIVEIRA, R.E. Aspectos da dinâmica de um fragmento florestal em Piracicaba - SP: silvigênese e ciclagem de nutrientes. Piracicaba, 1997. 87 p. Dissertação 
(Mestrado) - Escola Superior de Agricultura Luiz de Queiroz. Universidade de São Paulo.

OLSON, J.S. Energy storage and the balance of producers and decomposers in ecological systems. Ecology, v. 44, n. 2, p. 322-331, 1963.

OVINGTON, J.D. Some factors affecting nutrient distribuition. In: ECKARDT, F.E. (Ed.) Copenhagen: UNESCO, 1968. Functioning of terrestrial ecosystems at the primary production level. Proceedings of the Copenhagen Symposium, 1, 1968, p. 95-105.

PAGANO, S.N. Produção de folhedo em em mata mesófila semidecídua no município de Rio Claro, SP. Revista Brasileira de Biologia, v. 49, n. 3, p. 633-639, 1989.

PARDÉ, J. Le microclimat en forest. In: PESSON, P. (Ed.) Ecologie Forestière. Paris: Gauther-Villas, 1974, p. 1-19.

PEREIRA, J.M.S. Os ciclos biogeoquímicos nos ecossistemas florestais e agrícolas. Lisboa: Instituto Superior de Agronomia, 1978.

PETERSON, D.L.; ROLFE, G.L; BAZZAZ, F.A. Nutrient dynamics of litterfall and decomposition in a Bottomland Hardwood Forest. Forest Research Report, n.79-4, 4p., Dec. 1979.

POGGIANI, F. Ciclagem de nutrientes e manutenção da produtividade da floresta plantada. In: PENEDO, W.R. (Ed.), Gaseificação da madeira e carvão vegetal Belo Horizonte: Fundação Centro Tecnológico de MG./CETEC., 1981. 1v. (Série de Publicações Técnicas, v.4).

POGGIANI, F. Ciclagem de nutrientes em ecossistemas de plantações de Eucalyptus e Pinus. Implicações silviculturais. Piracicaba, 1985. 229 p. Tese (Livre-Docência). Escola Superior de Agricultura Luiz de Queiroz - Universidade de São Paulo. 
POGGIANI, F. Produção de biomassa e balanço nutricional em plantações de eucaliptos e pinheiros. Implicações silviculturais. Piracicaba: ESALQ, DCF, 1986, 20p.

POGGIANI, F. Alterações dos ciclos biogeoquímicos em florestas. Revista do Instituto Florestal, v. 4 (único), p. 734-739, mar. 1992.

POGGIANI, F.; SCHUMACHER, M.V. Ciclagem de nutrientes em florestas nativas. In: GONÇALVES, J.L.M.; BENEDETTI, V. (Eds.) Nutrição e Fertilização Florestal. Piracicaba: IPEF, 2000, cap. 10, p. 287-308.

POGGIANI, F.; MONTEIRO JÚNIOR, E.S. Deposição de folhedo e retorno de nutrientes ao solo numa floresta estacional semidecídua em Piracicaba, SP. In: CONGRESSO FLORESTAL BRASILEIRO, 6, Campos de Jordão, 1990. Anais. São Paulo: SBS/SBEF, 1990. p. 596-602.

POGGIANI, F.; SCHUMACHER, M. V. Atmospheric inputs compared with nutrient removed by harvesting from Eucalyptus plantation: implications for sustainability. In: IUFRO CONFERENCE ON SILVICULTURE AND IMPROVEMENT OF EUCALYPTS, Salvador, 1997. Anais. Colombo: EMBRAPA/CNPF, 1997. v.4, p. 68-74.

POGGIANI, F.; STAPE, J.L.; GONÇALVES, J.L.M. Indicadores de sustentabilidade das plantações florestais. Série Técnica IPEF, v. 12, n. 31, p. 33-44, abr. 1998.

POGGIANI, F.; COUTO, H.T.Z.; CORRADINI, L.; FAZZIO, E.C.M. Exportação de biomassa e nutrientes através da exportação dos troncos e das copas de um povoamento de Eucalyptus saligna. IPEF, v. 25, p.37-39, 1983.

PONCE, R.H. Perspectivas do eucalipto na substituição de madeiras nativas, SEMADER - SEMINÁRIO SOBRE PROCESSAMENTO E UTILIZAÇÃO DE MADEIRAS DE REFLORESTAMENTO, 3 ,Curitiba, 1994. Anais. Curitiba, p. 4146, 1994. 
POWERS, R.F. Nutrient requeriments of timber species. An overview. CALIFORNIA FOREST SOIL FERTILITY CONFERENCE, 5, Sacramento, Proceedings. Sacramento, California, 1976.

PRITCHETT, W.L. Properties and management of forest soils. New York: John Wiley and Sons, 1987. 500p.

PRITCHETT, W.L.; WELLS, C.G. Harvesting and site preparation increase nutrient mobilization. In: TIPPIN, T. (Ed.). A SYMPOSIUM ON PRINCIPLES OF MAINTAINING PRODUCTIVITY ON PREPARED SITES, New Orleans, LA: U.S. Forest Service and Southern Region of the Association of State College and University Research Organizations at Mississippi State University, 1978. Anais. New Orleans, LA, 1978.

RAISON, R.J.; CRANE, W.J.B. Nutritional costs of shortened rotations in plantation forestry. In: IUFRO WORLD CONGRESS, 17, Kyoto, 1981. Anais. Kyoto, p. 6372.

RAISON, R.J.; KHANA, P.K.; CRANE, W.J.B. Effects of Intensified Harvesting on Rates of Nitrogen and Phosphorus Removal From Pinus radiata and Eucalypts Forests in Australia and New Zealand. Journal of Forestry Science, v. 12, p. 394403, 1982.

REIS, M.G.F; BARROS, N.F. Ciclagem de nutrientes em plantios de eucalipto. In: BARROS, N.F.; NOVAIS, R.F. Relação Solo-Eucalipto. Viçosa: Ed. Folha de Viçosa, 1990. p. 265-301.

REIS, M.G.F; REIS, G.G.; BARROS, N.F.; SANTANA, R.C. Redução da biomassa durante a decomposição de folhas verdes de E. grandis, E. citriodora, E. cloeziana e E. torelliana. In: CONGRESSO FLORESTAL BRASILEIRO, 6, Campos do Jordão, 1990. Anais. Campos do Jordão: SBS/SBEF, 1990. v.3, p. 419-421. 
REMEZOV, N.P. Decomposition of forest litter and the cycle of elements in na oak forest. Soviet Soil Science, v.7, p. 703-711, 1961.

REZENDE, G.C.; BARROS, N.F.; MORAES, T.S.A.; MENDES, C.J. Produção e macronutrientes em florestas de eucalipto sob duas densidades de plantio. Revista Árvore, v. 7, n. 2, p. 165-176, 1983.

SÃO PAULO (Estado). Secretaria do Estado do Meio Ambiente. Coordenadoria de Informações Técnicas, Documentação e Pesquisa Ambiental. Inventário Florestal do Estado de São Paulo. São Paulo: Instituto Florestal, 1993.

SARRUGE, J.R.; HAAG, H.P. Análise química em plantas. Piracicaba: ESALQ, 1974, $56 \mathrm{p}$.

SAS INSTITUTE CORPORATION. The SAS-system for windows: release 6.11 (software). Cary, 1996.

SCHUMACHER, M.V. Aspectos da ciclagem de nutrientes e do microclima em talhões de Eucalyptus camaldulensis Dehnh, Eucalyptus grandis Hill ex Maiden e Eucalyptus torelliana F. Muell. Piracicaba, 1992. 104 p. Dissertação (Mestrado). Escola Superior de Agricultura Luiz de Queiroz, Universidade de São Paulo.

SCHUMACHER, M.V. Estudo da biomassa e dos nutrientes de um povoamento de Eucalyptus globulus (Labillardière) subespécie Bicostata. Revista Árvore, ViçosaMG, v.22, p. 281-286, 1998.

SCHUMACHER, M.V. Estudo da biomassa e dos nutrientes de um povoamento de Eucalyptus globulus subespécie Bicostata. In: IUFRO CONFERENCE ON SILVICULTURE AND IMPROVEMENT OF EUCALYPTS, Salvador, 1997. Anais. Salvador, 1997, v.3, p. 199-203.

SHANKS, R.; OLSON, J.S. First year breakdown of leaf litter in Southern Appalachian Forest. Science, v. 134, p. 194-195, 1961. 
SILVA, H.D. Modelos matemáticos para a estimativa da biomassa e do conteúdo de nutrientes em plantações de Eucalyptus grandis de diferentes idades. Curitiba, 1996. 101p. Tese (Doutorado). Universidade Federal do Paraná.

SILVA, H.D. Biomassa e aspectos nutricionais de cinco espécies do gênero Eucalyptus plantadas em solo de baixa fertilidade. Piracicaba, 1983. 92p. Dissertação (Mestrado). Escola Superior de Agricultura Luiz de Queiroz, Universidade de São Paulo.

SPAROVEK, G. Amostragem e análise de dados edafo-bio-climáticos de um remanescente florestal no município de Pindorama (SP). Piracicaba, 1993. 132p. Tese (Doutorado). Escola Superior de Agricultura Luiz de Queiroz, Universidade de São Paulo.

SPURR, S.H.; BARNES, B.V. Forest ecology. 3.ed. New York: Ronald Press, 1980. $571 \mathrm{p}$.

STREET, H. E.; ÖPIK, H. Fisiologia das Angiospermas: crescimento e desenvolvimento. São Paulo, EDUSP, 1974. 332p.

SWITZER, G.L.; NELSON, L.E. Maintenance of productivity under short rotations. In: FAO-IUFRO INTERNATIONAL SYMP. FOREST FERTILIZATION. Anais. Paris, 1973.

TIMONI, J.L. Ciclagem de nutrientes em talhão de Pinus kesya Royle ex Gordon, com e sem desbaste, no município de Itirapina (SP). Rio Claro, 1990. 114p. Tese (Doutorado). Universidade Estadual Paulista.

TURNER, J.; LAMBERT, M.J. Nutrient cycling within a 27-years-old Eucalyptus grandis plantation in New South Wales. Forest Ecology and Management, v. 6 (1983), n. 2, p. 155-168, 1983. 
VESTERDAL, L.; DALSGAARD, M.; FELBY, C.; RAULUND-RASMUSSEN, K.; JORGENSEN, B.B. Effects of thinning and soil properties on accumulation of carbon, nitrogen and phosphorus in the forest floor of Norway spruce stands. Forest Ecology and Management, v. 77:1-3, p. 1-10, 1995.

VIEIRA, S.A. Efeito das plantações florestais (Eucalyptus sp.) sobre a dinâmica de nutrientes em região de cerrado do Estado de São Paulo. Dissertação (Mestrado). Piracicaba, 1998. 73p. Escola Superior de Agricultura Luiz de Queiroz, Universidade de São Paulo.

VITOUSEK, P.M.; REINERS, W.A. Ecosystem succession and nutrient retention: a hypothesis. BioScience, v. 25, n.6, p.376-381, 1975.

WARING, R.H.; SCHLESINGER, W.H. Forest Ecosystems Concepts and Management. Orlando: Academic Press, 1985. 339p.

WEELS, C.G.; JORGENSEN, J.R. Effects of intensive harvesting on nutrient supply and sustained productivity. In: Impact of Intensive Harvesting on Forest Nutrient Cycling, p. 212-230, 1979.

WHATLEY, J.M.; WHATLEY, F.R. A luz e a vida das plantas. São Paulo: EPU - Ed. da Universidade de São Paulo, 1982. 103p.

WISE, P.K.; PITMAN, M.G. Nutrient removal and replacement associated with short rotation eucalypt plantation. Australian Forestry, v. 44, n.3, p.142-152, 1981. 